\begin{abstract}
UNIVERSIDADE DE SÃO PAULO
ESCOLA DE ENGENHARIA DE SÃO CARLOS

CENTRO DE RECURSOS HÍDRICOS E ESTUDOS AMBIENTAIS

PROGRAMA DE PÓS-GRADUAÇÃO EM CIÊNCIAS DA ENGENHARIA AMBIENTAL
\end{abstract}

FELIPPE FERNANDES

ENRIQUECIMENTO GEOQUÍMICO DE METAIS EM TESTEMUNHOS DE SEDIMENTOS, CORRELACIONADO COM GRANULOMETRIA E TEORES DE MATÉRIA ORGÂNICA

São Carlos

Estado de São Paulo

Agosto de 2015 
FELIPPE FERNANDES

\title{
ENRIQUECIMENTO GEOQUÍMICO DE METAIS EM TESTEMUNHOS DE SEDIMENTOS, CORRELACIONADO COM GRANULOMETRIA E TEORES DE MATÉRIA ORGÂNICA
}

\begin{abstract}
Dissertação apresentada à Escola de Engenharia de São Carlos, Universidade de São Paulo, como parte dos requisitos para obtenção do título de Mestre em Ciências da Engenharia Ambiental.
\end{abstract}

Área de concentração: Ciências da engenharia ambiental

Orientador: Prof. Dr. Cristiano Poleto

São Carlos

Estado de São Paulo 
Agosto de 2015

AUTORIZO A REPRODUÇÃO TOTAL OU PARCIAL DESTE TRABALHO, POR QUALQUER MEIO CONVENCIONAL OU ELETRÔNICO, PARA FINS DE ESTUDO E PESQUISA, DESDE QUE CITADA A FONTE.

F363e Fernandes, Felippe

ENRIQUECIMENTO GEOQUÍMICO DE METAIS EM TESTEMUNHOS DE SEDIMENTOS CORRELACIONADO COM GRANULOMETRIA E TEORES DE MATÉRIA ORGÂAICA / Felippe Fernandes; orientador Cristiano Poleto. São Carlos, 2015.

Dissertação (Mestrado) - Programa de Pós-Graduação em Ciências da Engenharia Ambiental e Área de Concentração em Ciências da Engenharia Ambiental -Escola de Engenharia de São Carlos da Universidade de São Paulo, 2015.

1. Sedimentos. 2. Metais. 3. Elementos-traço. 4. Carbono Orgânico Total. 5. Granulometria. 6. Índice de geoacumulação. 7. Barragem Mãe d' Água. I. Título. 


\section{FOLHA DE JULGAMENTO}

Candidata: Bacharel FELIPPE FERNANDES.

Título da dissertação: "Enriquecimento geoquímico de metais em testemunhos de sedimentos correlacionado com granulometria e teores de matéria orgânica".

Data da defesa: $21 / 08 / 2015$

Comissāo Julgadora:

Prof. Dr. Cristiano Poleto (Orientador)

(Universidade Federal do Rio Grande do SUl/UFRGS)

\section{Resultado:}

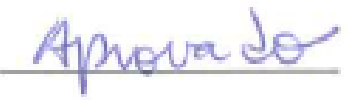

Aprovado

Profa. Dra. Simone Andrea Furegatti

(Universidade Estadual Paulista "Júlio de Mesquita Filho"/UNESP- Bauru)

Dr. Renato Billia de Miranda

Apsenodo (Pesquisador FIPAI)

Coordenador do Programa de Pós-Graduação em Ciências da Engenharia Ambiental:

Prof. Associado Frederico Fabio Mauad

Presidente da Comissão de Pós-Graduação:

Prof. Associado Paulo César Lima Segantine 


\section{DEDICATÓRIA}

Dedico este trabalho primeiramente a Deus, aos meus Pais, Osvaldo e Cláudia, a minha noiva Manoela que sempre estiveram ao meu lado e formam a base da minha vida. Aos amigos que estiveram sempre ao meu lado nesses anos de luta. Aos meus avós que já se foram, mas deixaram uma base forte e constante a mim. 


\section{AGRADECIMENTOS}

$\checkmark$ A Deus, pela oportunidade de trabalhar e crescer frente às dificuldades e desafios da vida.

$\checkmark$ Um agradecimento especial ao meu orientador, Prof. Dr. Cristiano Poleto, pela orientação, confiança e profissionalismo e que ao longo de anos do mestrado, demonstrou ser um grande amigo, tendo me apoiado e motivado a dar continuidade a vida acadêmica. Uma grande pessoa e motivo de admiração pelo seu profissionalismo.

$\checkmark$ Agradeço aos meus pais, Osvaldo e Cláudia, que me deram todo suporte necessário e incentivo durante toda a minha trajetória nos estudos, aos conselhos, acolhimento em períodos de dificuldades e pelo amor que é base para as conquistas e essência da vida.

$\checkmark$ À Manoela Jorge Campos, minha noiva, pela ajuda em momentos difíceis, dando todo seu apoio, carinho, motivação, amor e confiança em toda a trajetória e sempre presente em minha vida. Espero passar a minha vida ao teu lado!

$\checkmark$ À minha nova família, Camilo, Rosemary, Amilton, Rosana, Gabriela e Aparecida, que sempre me acolheram muito bem e demonstram sempre um enorme carinho. A todos, muito obrigado!

$\checkmark$ Aos amigos, os poucos e bons, que fazem da vida mais alegre. Especialmente ao Eduardo e Renato, pela amizade e parceria nos estudos, sempre prestativos. E aos colegas da pósgraduação USP, especialmente ao Núcleo de Hidrometria Obrigado!

$\checkmark$ A todos os professores da Pós-Graduação pela disposição nas aulas, mesmo fora das aulas sempre muito dispostos, e atenção tenho a certeza que se tornarem meus amigos, não mediram esforços para me aconselhar e ajudar em minha formação.

$\checkmark$ Aos componentes da banca, que com seu conhecimento consolidado muito contribuíram para a construção deste trabalho. Em particular ao professor Dr. Frederico Fábio Mauad, pelo apoio logístico e institucional, sempre que foi preciso.

$\checkmark$ Aos Laboratórios: de Análises de Solo (Faculdade de Agronomia/UFRGS), na figura da Lizandra, de Sedimentometria (IPH/UFRGS), na figura do hidrotécnico Bruno e Arron, ao Laboratório de Sedimentologia do CECO/IGEO/UFRGS, na figura do técnico Gilberto Rodrigues, pelo auxílio na realização das coletas dos testemunhos e apoio no processamento das amostras.

$\checkmark$ Ao CNPq pela concessão da bolsa de estudos e pelo financiamento da pesquisa ao FINEP Projeto MAPLU2. 
"Tudo tem seu apogeu e seu declínio.

É natural que seja assim, todavia, quando tudo parece convergir para o que supomos o nada, eis que a vida ressurge, triunfante $e$ bela! Novas folhas, novas flores, na infinita benção do recomeço!"

Chico Xavier 


\section{RESUMO}

FERNANDES, F. Enriquecimento geoquímico de metais em testemunhos de sedimentos correlacionado com granulometria e teores de matéria orgânica. 2015. 103 f. Dissertação -(Mestrado em Ciências da Engenharia Ambiental)-Escola de Engenharia de São Carlos, Universidade de São Paulo, São Carlos, 2015.

O Município de Viamão está localizado na região metropolitana de Porto Alegre, no estado do Rio Grande Sul. A barragem Mãe d’Água foi construída em 1962, com o intuito de atender à demanda da Universidade Federal do Rio Grande do Sul, mais precisamente o Instituto de Pesquisas Hidráulicas, porém, devido à falta de planejamento urbano, durante os últimos quarenta anos, vem acarretando uma diversificada série de passivos ambientais, como contaminantes orgânicos e/ou inorgânicos. Neste seguimento, o presente trabalho busca avaliar as concentrações dos metais Zinco e Níquel, teores de matéria orgânica e a composição granulométrica nas diferentes profundidades amostradas em testemunhos de sedimentos produzidos nesta bacia hidrográfica que compõe a barragem Mãe d’Água. As coletas de amostras foram realizadas em junho de 2014, sendo amostrados quatro testemunhos sedimentares distribuídos no lago da referida barragem. Para a extração dos testemunhos foi utilizado um amostrador de núcleo "Piston Core". Os sedimentos da fração menor que $63 \mu \mathrm{m}$ foram destinados a análise química para verificação da presença e concentração dos elementos traço: Níquel (Ni) e Zinco (Zn). A metodologia de digestão ácida empregada é a EPA 3050, adotada pela U.S. Environment Protection Agency, sendo que as análises foram realizadas em duplicata e, para controle de qualidade, foram utilizados dois materiais de referência da USGS (U.S. Geological Survey): SGR-1b e SCO-1. Com os resultados obtidos, a caracterização granulométrica da sedimentação sob o barramento mostrouse suscetível a contaminação por metais ao longo nas últimas décadas. Todas as amostras apresentaram concentrações de Zn e Ni acima do valor de background local e com padrões de crescimento, portanto, evidenciam a existência de enriquecimento dos sedimentos por estes elementos. Os teores de matéria orgânica quando correlacionados as concentrações de $\mathrm{Zn}$ e Ni evidenciaram o crescente enriquecimento nos testemunhos analisados, confirmando a alta afinidade destes elementos à sedimentos compostos de fração orgânica. O índice de geoacumulação para a maior parte das concentrações dos metais nas diferentes profundidades encontra-se caracterizadas como não poluída. Considerando que a área de estudo se caracteriza historicamente pela ocupação residencial, ações antropogênicas podem ser consideradas as principais provedoras dos passivos ambientais aos corpos d’água.

Palavras-chave: Sedimentos. Metais. Elementos-traço. Carbono orgânico total. Granulometria. Índice de geoacumulação. Barragem Mãe d’ Água. 


\begin{abstract}
FERNANDES, F. Geochemical enrichment of metals in sediment cores correlated with soil texture and organic matter content. 2015. 103 f. Dissertation-(Master Environmental Engineering Sciences)-School of Engineering of São Carlos, University of São Paulo, São Carlos, 2015.
\end{abstract}

The Municipality of Viamão is located in the metropolitan region of Porto Alegre, state of Rio Grande do Sul. The Mãe D’água Dam was built in 1962, so that demands from the Federal University of Rio Grande do Sul, more precisely the Institute of Hydraulic Research could be met. However, due to a lack of urban planning over the past forty years, the dam has caused several environmental liabilities, such as organic contaminants and / or inorganic contaminants. This manuscript addresses an evaluation of the concentrations of the metals zinc and nickel metals, organic matter content and particle size composition at different depths sampled in sediment cores produced in the watershed that comprises Mãe d'Água. Four sediment core distributed in the dam lake were collected in June 2014, by "Piston Core" core sampler. Sediments whose fraction was lower than $63 \mu \mathrm{m}$ were subjected to chemical analyses regarding the presence and concentration of nickel (Ni) and zinc (Zn). The acid digestion methodology employed was EPA 3050, adopted by the US Environment Protection Agency. The analyses were performed in duplicate and two USGS (US Geological Survey) reference materials, namely: SGR-1b and SCO-1 were used for the quality control. The particle size characterization of sedimentation under the bus has proved susceptible to metal contamination over the past decades. All samples showed concentrations of $\mathrm{Zn}$ and Ni higher than the local background values and growth patterns, which evidenced an enrichment of sediments. In comparison to the organic matter content, the $\mathrm{Zn}$ and $\mathrm{Ni}$ concentrations showed a growing enrichment, which confirmed the high affinity of these elements for sediments composed of organic fraction. The geoaccumulation index for most of the metal concentrations at different depths has been characterized as non polluted. As whereas the study area is historically by historically residential occupation, anthropogenic actions can be considered the main causes of environmental damage to water bodies.

Keywords: Sediments. Metals. Trace elements. Total organic carbon. Grain Size. Geoaccumulation index. Dam Mãe d’Água. 


\section{SUMÁRIO}

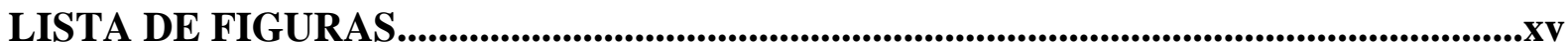

LISTA DE TABELAS............................................................................................................................

LISTA DE SIGLAS E ABREVIAÇÕES..................................................................................xix

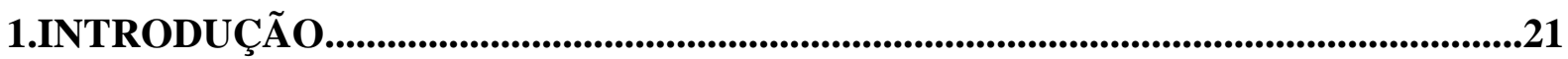

2.OBJETIVOS................................................................................................................................23

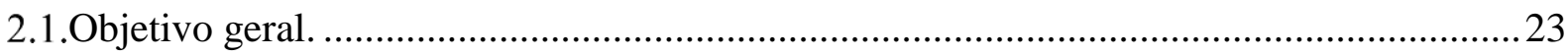

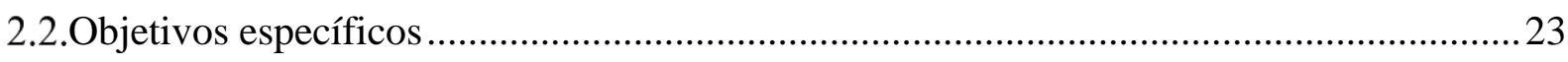

3.HIPÓTESE..............................................................................................................................24

4.REVISÃO BIBLIOGRÁFICA..........................................................................................25

4.1.Histórico dos impactos da urbanização e degradação dos ecossistemas lacustres...............25

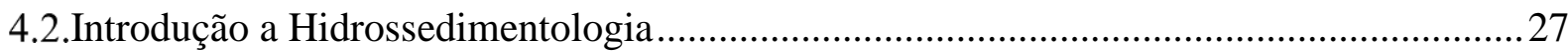

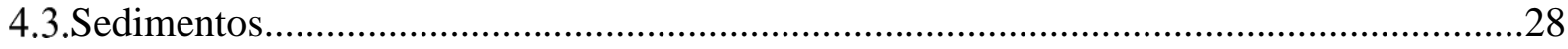

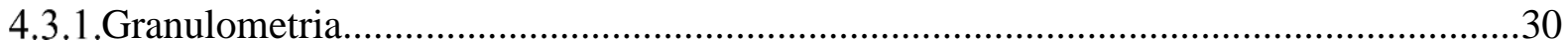

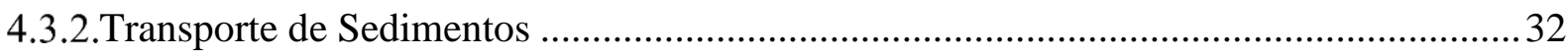

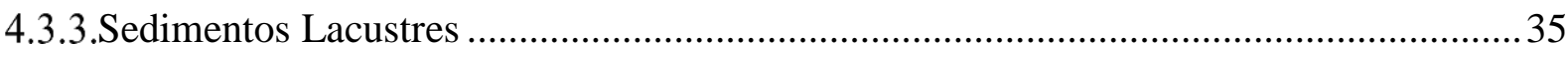

4.4.Qualidade dos sedimentos urbanos frente aos processos de urbanização ………………......36

4.5.Contaminação dos sedimentos por metais pesados ……………………………………......39

4.6.Matéria Orgânica Presente nos Sedimentos (M.O.) …………………………………..... 40

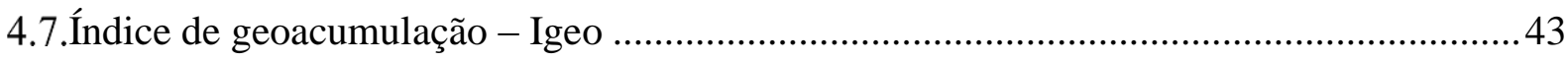

4.8.Digestão da Amostra ou Abertura da amostra.................................................................. 45

4.9.Análise Espectrometria de Emissão com Plasma Acoplado Indutivamente (ICP OES) ....46

4.10.Relação dos sedimentos com o nível de poluição (Background) ………………………....46

5.CARACTERIZAÇÃO DA ÁREA DE ESTUDO.............................................................48

5.1.Interferências antropogênicas na Represa Mãe d’Água .......................................................4 48

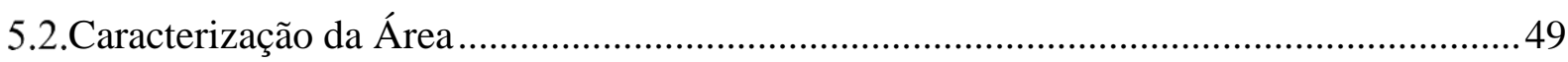


6.MATERIAL E MÉTODOS........................................................................................................53

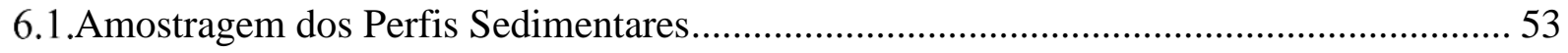

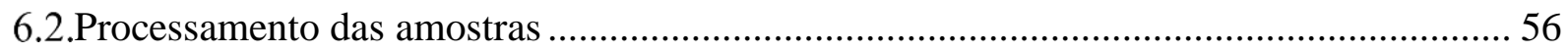

6.3.Teores de Matéria Orgânica Total ou (COT) …................................................................. 59

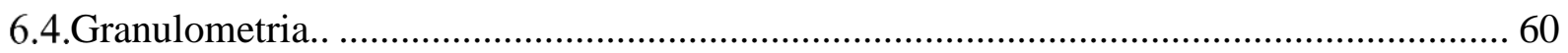

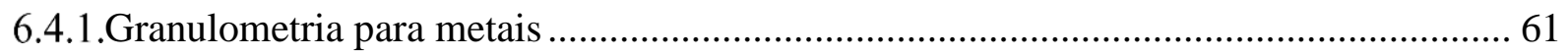

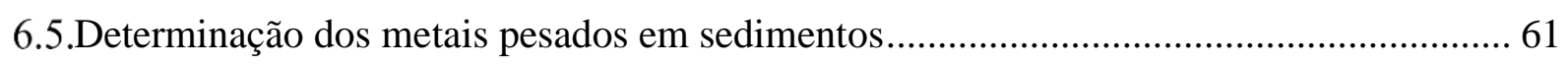

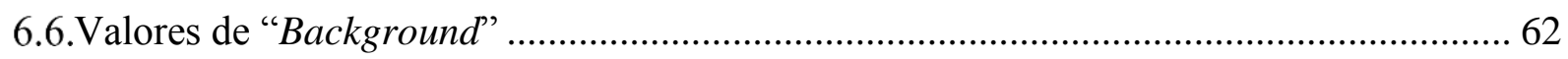

7.RESULTADOS E DISCUSSÃO ..............................................................................63

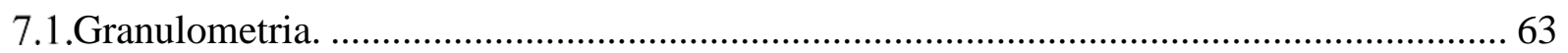

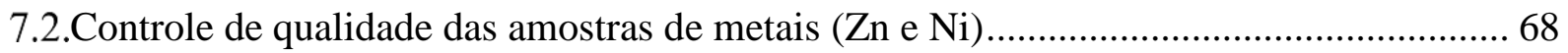

7.3.Concentrações totais de zinco e níquel nos testemunhos sedimentares ............................. 69

7.3.1.Concentrações total de zinco nos testemunhos de sedimentos ..................................... 69

7.3.2.Concentrações totais de níquel nos testemunhos de sedimentos ................................... 74

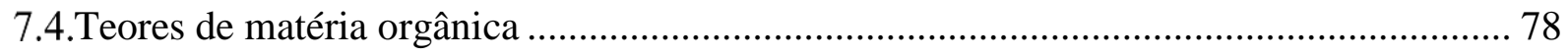

7.4.1.Teores de matéria orgânica correlacionados ao Zinco $(\mathrm{Zn})$....................................... 78

7.4.2.Teores de matéria mrgânica correlacionados ao Níquel (Ni) ...................................... 81

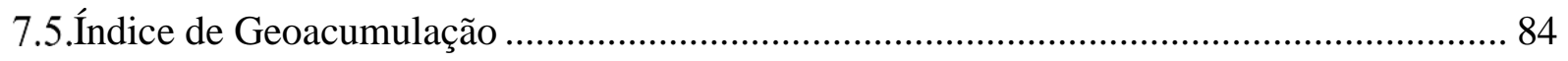

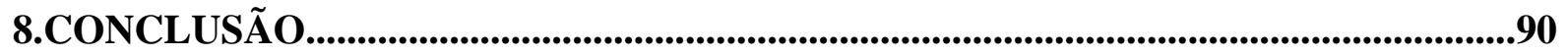

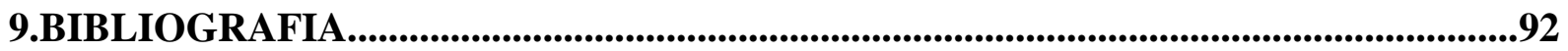




\section{LISTA DE FIGURAS}

Figura 1 - Diferenciação de hidrogramas de uma bacia urbanizada para não urbanizada.......27

Figura 2- Escalas granulométricas adotadas pelas ASTM, AASHTO, MIT e ABNT..............31

Figura 3 - Modos de transporte de partículas nos corpos hídricos.......................................33

Figura 4 - Origem e destinação dos sedimentos em ambientes urbanos.................................37

Figura 5 - Diagrama do fluxo ambiental da matéria orgânica...............................................41

Figura 6 - Aspectos das águas no vertedor da barragem Mãe d'água....................................49

Figura 7- Localização e representação do represamento em estudo na Região Metropolitana de

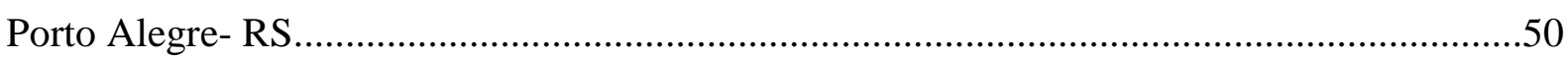

Figura 8- Carta imagem da área de estudo, base na imagem Quickbird do ano de 2003.........51

Figura 9 - Distribuição espacial dos pontos amostrados no lago...........................................54

Figura 10 - Extração do testemunho 4 no lago da barragem Mãe d'água...................................55

Figura 11 - Testemunhos coletados e prontos para seguir ao laboratório................................55

Figura 12 - Abertura do tubo de $75 \mathrm{~mm}$ de diâmetro que preserva as amostras coletadas, (Testemunho 4).

Figura 13 - Testemunho 4, aberto após a coleta na mesa de abertura esterilizada...................57

Figura 14- Testemunhos fatiados a cada 2 centímetros........................................................58

Figura 15-Armazenamento das sub-amostras em recipientes estéreis de PVC.......................58

Figura 16- Fotografia do equipamento Thermo Scientific Flash 2000- NC Soil Analyzer......59

Figura 17- Processamento das amostras para inserção no equipamento Flash 2000- NC Soil Analyzer.

Figura 18 - Classificação de acordo com o triângulo textural referente ao testemunho de sedimento 1 do barramento Mãe d'Água.

Figura 19 - Classificação de acordo com o triângulo textural referente ao testemunho de sedimentos 4 do barramento Mãe d'Água.

Figura 20 - Classificação de acordo com o triângulo textural referente ao testemunho de sedimentos 6 do barramento Mãe d'Água 
Figura 21 - Classificação de acordo com o triângulo textural referente ao testemunho de sedimentos 8 do barramento Mãe d'Água. .68

Fonte adaptado de Gerakis e Baer (1999). .68

Figura 22 - Distribuição dos teores de zinco em profundidade nos diferentes testemunhos de sedimentos do barramento Mãe d’Água. .73

Figura 23 - Distribuição dos teores de níquel (em ppm) em profundidade nos diferentes testemunhos de sedimentos do barramento Mãe d'Água. . .75

Figura 24 - Regressão linear entre as porcentagens de carbono orgânico total e teores de zinco correspondentes ao testemunho 1 de sedimentos do barramento Mãe d’Água. .79

Figura 25 - Regressão linear entre as porcentagens de carbono orgânico total e teores de zinco correspondentes ao testemunho 4 de sedimentos do barramento Mãe d'Água .79

Figura 26 - Regressão linear entre as porcentagens de carbono orgânico total e teores de zinco correspondentes ao testemunho 6 de sedimentos do barramento Mãe d'Água. .80

Figura 27 - Regressão linear entre as porcentagens de carbono orgânico total e teores de zinco correspondentes ao testemunho 8 de sedimentos do barramento Mãe d’Água. .80

Figura 28 - Regressão linear entre as porcentagens de carbono orgânico total e teores de níquel correspondentes ao testemunho 1 de sedimentos do barramento Mãe d'Água. .82

Figura 29 - Regressão linear entre as porcentagens de carbono orgânico total e teores de níquel correspondentes ao testemunho 4 de sedimentos do barramento Mãe d’Água.

Figura 30 - Regressão linear entre as porcentagens de carbono orgânico total e teores de níquel correspondentes ao testemunho 6 de sedimentos do barramento Mãe d’Água.

Figura 31 - Regressão linear entre as porcentagens de carbono orgânico total e teores de níquel correspondentes ao testemunho 8 de sedimentos do barramento Mãe d’Água.

Figura 32- Classificação dos valores do Igeo para Zn em profundidade nos diferentes testemunhos de sedimentos do barramento Mãe d'Água.....

Figura 33- Classificação dos valores do Igeo para Ni em profundidade nos diferentes testemunhos de sedimentos do barramento Mãe d'Água. .88 


\section{LISTA DE TABELAS}

Tabela 1 - Classificação dos Igeo .44

Tabela 2 - Informações dos testemunhos coletados 53

Tabela 3 - Valores de base dos metais-traço analisados. 62

Tabela 4- Classificação granulométrica (\%) em diferentes profundidades (cm) dos testemunhos amostrados .64

Tabela 5 - Concentrações de Zn e Ni da amostra de referência Green River Shale (SGR-1b) e Cody Shale (SCo-1) da USGS ${ }^{\mathrm{a}}$ .69

Tabela 6 - Concentração de Zn (mg.kg $\left.{ }^{-1}\right)$ nos sedimentos acumulados no Lago Mãe d'Água....71

Tabela 7 - Concentração de Ni (mg.kg-1 $)$ nos sedimentos acumulados no Lago Mãe d'Água.....76

Tabela 8- Resultado dos cálculos de Igeo para os testemunhos de sedimentos de fundo. Concentrações de background em (mg.kg $\left.{ }^{-1}\right)$ 
xviii 


\section{LISTA DE SIGLAS E ABREVIAÇÕES}

$\mu \mathrm{m} \quad$ Micrômetro

AASHTO American Association for State Highway and Transportation Officials

ABNT Associação Brasileira de Normas Técnicas

Al Alumínio

ASE Área Superficial Específica

ASTM American Society for Testing Materials

CHREA Centro de Recursos Hídricos e Estudos Ambientais

$\mathrm{cm} \quad$ Centímetros

COT Carbono Orgânico Total

$\mathrm{Cu} \quad$ Cobre

EAA Espectrometria de Absorção Atômica

EESC Escola de Engenharia de São Carlos

FeS Sulfeto de ferro

$\mathrm{H}_{2} \mathrm{O}_{2} \quad$ Peróxido de hidrogênio

$\mathrm{HCl} \quad$ Ácido clorídrico

$\mathrm{HNO}_{3} \quad$ Ácido nítrico

Igeo Índice de geoacumulação

ICP-OES Espectrometria de Emissão com Plasma Acoplado Indutivamente

IPH Instituto de Pesquisas Hidráulicas

m Metros

MO Matéria orgânica

MIT Massachusetts Institute of Technology

MRP Materiais de referência padrão

$\mathrm{Ni} \quad$ Níquel

$\mathrm{Pb} \quad$ Chumbo

PPG-SEA Programa de Pós-Graduação em Ciências da Engenharia Ambiental

ppm Partes por milhão

SCo-1 Cody Shale

SGR-1b Green River Shale

T1 Testemunho 1 
Testemunho 4

T6

Testemunho 6

$\mathrm{T} 8$

Testemunho 8

USEPA Environment Protection Agency

UFRGS Universidade Federal do Rio Grande do Sul

USGS United States Geological Survey

USP Universidade de São Paulo

$\mathrm{Zn}$

Zinco 


\section{INTRODUÇÃO}

O crescimento urbano às margens ou no entorno dos ecossistemas aquáticos ocasiona a degradação da qualidade das águas, acarretando em prejuízos expressivos à comunidade aquática e a saúde pública. Aliado a este crescimento rápido e desordenado, o uso indevido do solo é atualmente uma das principais causas da degradação dos recursos naturais, gerando prejuízos não apenas pelas alterações hidrológicas, mas também pela carga de poluentes lixiviados ou carreados junto aos sedimentos, tendo por destino final a sedimentação em corpos d'água.

Compreender a dinâmica de sedimentos de uma bacia hidrográfica tem grande importância, por exemplo, sobre as alterações do uso e ocupação da terra, a urbanização ou o desenvolvimento econômico e dos impactos das mudanças climáticas.

Os sedimentos são encontrados em camadas na forma de partículas finamente divididas no fundo de rios, lagos, reservatórios, baias, estuários e oceanos. Esses consistem de maneira geral em vários minerais com granulação fina, média e grossa, incluindo argilas, silte e areia misturados com matéria orgânica, sendo que sua composição (mineral e orgânica) dependerá da Geologia e Biota local. Enquanto, o tamanho das partículas ou granulometria varia principalmente com as condições de sua origem (MANAHAN, 2000).

No ambiente urbanizado, há uma maior probabilidade de ocorrência dos metais entre os poluentes agregados aos sedimentos, gerados de forma natural e/ou antropogênica. Os metais, podem ser associados a contaminação, mas deve-se ter cautela ao analisar, a concentração do metal presente no sedimento crucial para a tomada de decisões devido a serem essenciais tanto às plantas quanto aos animais.

Os contaminantes orgânicos presentes nos sedimentos em ambientes anóxicos, são dotados de carbono orgânico, e quando sintetizado por bactérias anaeróbias, produzem o sulfeto de ferro $(\mathrm{FeS})$, disponibilizando a reação com outros íons metálicos divalentes solúveis (como $\left.\mathrm{Pb}^{2+}, \mathrm{Cu}^{2+}, \mathrm{Hg}^{2+}, \mathrm{Cd}^{2+}, \mathrm{Zn}^{2+} \mathrm{e} \mathrm{Ni}^{2+}\right)$, originando precipitados insolúveis ou de baixa solubilidade (PERIN et al. 1997). Segundo Hedge; Knott e Johnston (2009), a ressuspensão de sedimentos anóxicos em ambientes com oxigênio disponível, propiciam os processos de sorção, influenciando na biodisponibilidade dos metais dissolvidos na água.

Segundo Baird (2002), os elementos traço possuem sua densidade alta quando comparados com outros materiais, se caracterizam muitas vezes por causar riscos à saúde humana e se agregam as partículas de sedimentos ou solo em sua deposição final. A 
determinação granulométrica em sedimentos aquáticos tem significativa importância sobre os estudos biogeoquímicos, a maioria destes dos elementos-traços tende a se concentrar nos sedimentos de granulometria mais fina, principalmente nas frações silte e argila (fração menor que $63 \mu \mathrm{m}$ ). Segundo Mozeto (2006) os nutrientes e contaminantes, sendo eles íons metálicos ou compostos orgânicos, encontram-se predominantemente nas superfícies das partículas da fase sólida, ou seja, todo o material em suspensão, decantação ou mesmo já sedimentado e acumulado.

No processo de acumulação dos metais nos sedimentos, com ênfase nos ambientes aquáticos, a relação dos efeitos antrópicos com a ocorrência natural de deposição desses sedimentos pode ser identificada através da determinação do índice de geoacumulação de sedimentos. Este possui grande importância para o entendimento dos processos geoquímicos ocorridos no lago, transcrevendo o histórico do enriquecimento destes contaminantes nos sedimentos.

Identificar os reflexos da urbanização sobre o processo de enriquecimento dos sedimentos lacustres por metais e comparando-os com a concentração de matéria orgânica total e granulometria é de suma importância no campo da hidrossedimentologia, partindo do princípio de que a poluição gerada nos centros urbanos se agrega aos sedimentos depositados nos ecossistemas lacustres. 


\section{OBJETIVOS}

\subsection{Objetivo geral}

Relacionar as concentrações de Zinco e Níquel, com a granulometria e os teores carbono orgânico total obtidos através da amostragem em testemunhos, (Core Sampling), objetivando inferir sobre o enriquecimento dos sedimentos por metais depositados ao longo dos anos sobre o barramento Mãe d'Água.

\subsection{Objetivos específicos}

- Determinar as concentrações de Zinco e Níquel, teores de carbono orgânico total, e a granulometria no sedimento de fundo do barramento Mãe d'Água obtidos através da amostragem em "CORES”;

- Elaborar uma distribuição sobre a classificação granulométrica de acordo com o triângulo textural referentes aos testemunhos de sedimentos do barramento Mãe d'Água;

- Elaborar uma distribuição vertical das concentrações dos metais zinco e níquel relacionando-os com a profundidade de sua respectiva amostra e correlacionar com os valores de referência local (Background);

- Realizar regressões lineares entre as porcentagens de carbono orgânico total e as concentrações dos metais zinco e níquel;

- Calcular o índice de geoacumulação. 


\section{HIPÓTESE}

A urbanização sem planejamento, no que tange os âmbitos urbano, social e ambiental no interior de uma bacia hidrográfica, pode ocasionar um passivo à qualidade do meio ambiente, reincidindo diretamente nas concentrações de metais nos sedimentos presentes e acumulados nos corpos hídricos. Em um determinado ecossistema aquático pode ocorrer o processo de liberação/dessorção dos metais presentes nos sedimentos para a coluna d'água, sendo influenciado por fatores físico químicos, dentre eles a granulometria e os teores de carbono orgânico total. Frações granulométricas finas dos sedimentos possuem maior área superficial específica, sendo favorável a reações químicas e consequentemente pode levar a maior adsorção de metais, enquanto maiores teores de matéria orgânica podem agir como agentes complexantes destes elementos. Já o índice de geoacumulação pode inferir sobre uma medida quantitativa da poluição causada por metais nos sedimentos aquáticos, se aliando e podendo ser uma ferramenta de complemento a estudos sobre o enriquecimento dos metais em sedimentos. 


\section{REVISÃO BIBLIOGRÁFICA}

\subsection{Histórico dos impactos da urbanização e degradação dos ecossistemas lacustres}

Sabe-se que o crescimento urbano às margens de ecossistemas aquáticos causa a degradação da qualidade das águas levando à eutrofização artificial (TUNDISI, 2008). Segundo Esteves (1998), esse processo pode causar expressivos prejuízos à sociedade humana, por exemplo, problemas de saúde pública e de redução do potencial de irrigação, de produtividade pesqueira, de balneabilidade e de inúmeras outras possibilidades de uso pelos agentes sociais.

As consequências sobre os recursos hídricos têm gerado prejuízos não apenas pelas alterações hidrológicas, mas também pela carga de poluentes lixiviados ou carreados, gerando assim passivos ambientais que afetam a qualidade de vida da população e o equilíbrio ambiental das áreas de drenagem das bacias hidrográficas (NASCIMENTO et al.,2005).

Segundo Fujimoto (2001), ao realizar um estudo pela METROPLAN (Fundação Estadual de Planejamento Metropolitano e Regional), concluiu que por grande maioria, os resultados apontam os problemas relacionados ao meio físico, levantados na Região Metropolitana de Porto Alegre (RMPA), foram decorrente do uso e ocupação do solo, sendo notado a ocupação de áreas impróprias, sendo ausente o seu planejamento para o crescimento urbano e assim submete-se a um risco em potencial ao meio ambiente.

No município de Porto Alegre, em meados da década de 70, houve um aumento no desenvolvimento da malha viária urbana, o que estimulou a expansão do município e a interação com as cidades da região. Tal fato favoreceu principalmente a cidade de Viamão (FUJIMOTO, 2001).

Com a expansão da região de Porto Alegre em 1970, houve um crescimento de polos residenciais e industriais, sendo integrados com uma vasta malha viária, que proporcionou o crescimento de eixos periféricos onde contrariou os propostos, pois a princípio fomentava o desenvolvimento da área. Assim ficaram evidentes que nesses eixos estão atreladas 
características como a falta de planejamento, infraestrutura para um crescimento sadio do meio ambiente ali presente.

O lançamento de efluentes característico de esgoto somado com a ausência de tratamento e a adição de poluentes de origem química das mais diversas fontes levam a geração de passivos ambientais decorrentes da urbanização (POLETO e LAURENTI, 2008).

Poleto (2007) trata com importância as alterações ao meio ambiente provocadas pela urbanização e destaca a supressão e/ou substituição da vegetação nativa por áreas impermeabilizadas. O fato de impermeabilizar novas áreas implica no aumento do volume escoado superficialmente, em consequência da redução do volume interceptado pela vegetação e das alterações no ciclo hidrológico. Por influência do maior volume escoado nas áreas impermeáveis, o corpo d'água receptor desta vazão estará sujeito aos processos erosivos e enchentes.

Segundo Tucci e Genz (1995), o volume que escoava lentamente pela superfície do solo e ficava retido através da vegetação, com a urbanização, passa a escoar na bacia com uma maior velocidade em um menor tempo resultando em um pico de efeito negativo, sendo ele o aumento da vazão máxima (Figura 1).

$\mathrm{O}$ arraste de sedimentos é de expressivo conhecimento, pois o assoreamento dos reservatórios resultantes da lixiviação e carreamento dos sedimentos pode levar ao colapso e trazer problemas como enchentes, que em sua decorrência pode resultar em problemas sanitários, ou seja, envolver a saúde pública e de ordem social e econômica das mais diversas magnitudes. 


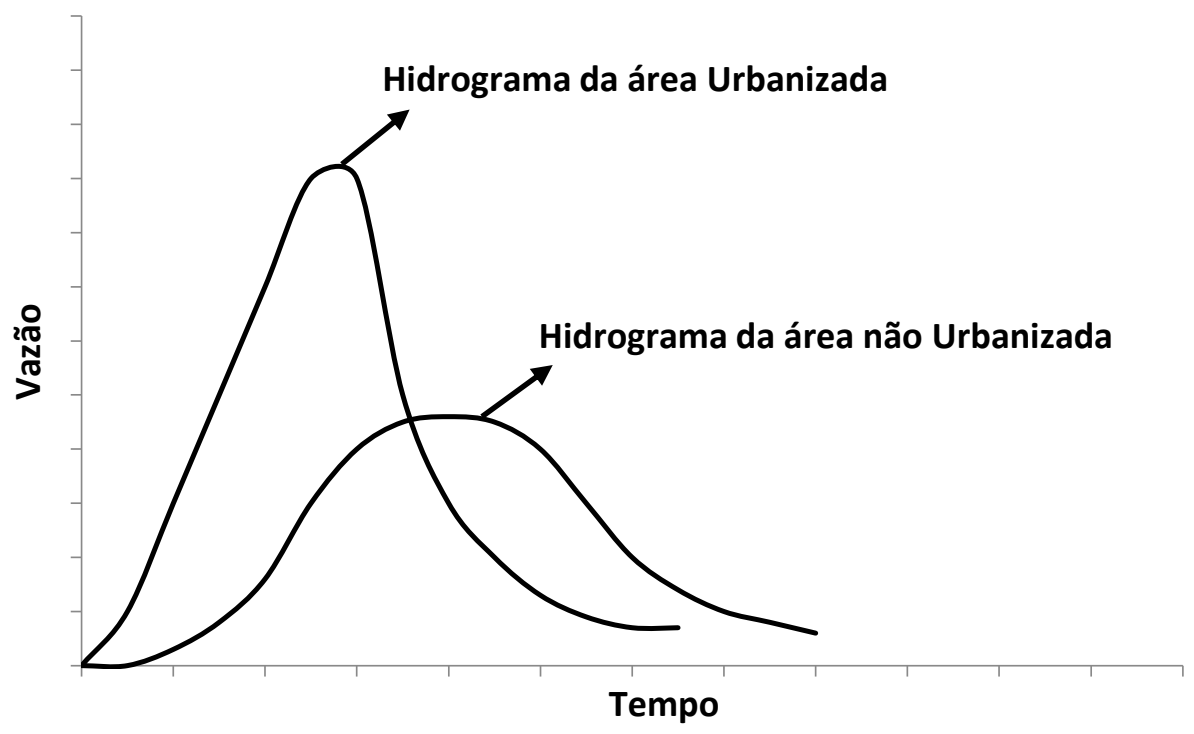

Figura 1 - Diferenciação de hidrogramas de uma bacia urbanizada para não urbanizada.

Fonte: Adaptado de TUCCI e GENZ (1995)

\subsection{Introdução a Hidrossedimentologia}

O estudo dos sedimentos, Sedimentologia, traz um amplo conhecimento de relevância mundial dentro do contexto dos estudos de processos como erosão, lixiviação, escoamento superficial do sedimento até o seu encontro com corpo hídrico.

De acordo com Bordas, Lanna e Semmelmann (1988), como ciclo hidrológico, existe outro ciclo, aberto e totalmente dependente ao ciclo da água, que envolve o deslocamento, o transporte e o depósito de partículas sólidas presentes na superfície da bacia. Com essas características e por analogia, é definido por ciclo hidrossedimentológico, ressaltando que os sedimentos não retornam ao meio que os provêm.

Atividades como a irrigação, agricultura, urbanização e industrialização, trazem para os corpos d'água maiores concentrações de sedimento. A origem dos sedimentos que chegam à região dos ecossistemas lacustre é variada, englobando desde a lixiviação da bacia de drenagem, à atmosfera, erosão dentro do corpo hídrico e sedimentos oriundos de atividade biológica. Assim, a natureza das fácies sedimentares é controlada pela quantidade e qualidade 
dos sedimentos disponíveis, pela interação dos processos hidrodinâmicos e pela geomorfologia do fundo (MIRANDA; CASTRO e KJERFVE, 2002).

Carvalho (2008) faz referência ao uso e ocupação inadequados do solo dentro das bacias hidrográficas e ações como o intemperismo decorrentes do meio ambiente, que estão ligados aos sedimentos e a associação de impactos desde a sua formação à deposição final.

Ao se realizar uma gestão integrada dos recursos hídricos, os riscos de degradação dos solos, dos leitos dos rios e dos ecossistemas fluviais e estuários, ou de contaminação dos sedimentos por produtos químicos, levaram a reconsiderar essa postura e a dar maior atenção aos problemas que podem decorrer das alterações do ciclo hidrossedimentológico natural. Além da erosão e da degradação do solo na agricultura, os prejuízos se estendem as mais derivadas formas como: assoreamento de reservatórios, tratamento de água, remoção de sedimentos de áreas atingidas pelas inundações (BORDAS e SEMMELMANN, 1988).

\subsection{Sedimentos}

Segundo Carvalho (2008), sedimento é a partícula derivada da rocha, ou materiais biológicos, que pode ser transportada por um fluído. Proveniente, a partir de partículas derivadas da fragmentação das rochas, por processos físicos e/ou químicos, e que é transportada pela água ou pelo vento do lugar de origem aos rios e aos locais de deposição, sendo o material sólido em suspensão na água ou depositado no leito.

No sistema aquático, o sedimento é o compartimento onde se depositam todos os compostos minerais, estruturas de animais e vegetais que não foram totalmente decompostos. Dessa maneira, ao longo da evolução de um sistema aquático formam-se camadas sobre o leito dos corpos hídricos com os sedimentos ali depositados, contendo compostos químicos e estruturas biológicas que representam as diferentes fases deste processo. Além desses, os agrotóxicos e os metais pesados também se depositam nos sedimentos, podendo ser utilizados como indicadores da contaminação ambiental. A sua distribuição na vertical é um importante indicador da evolução da poluição em ambientes aquáticos. Os sedimentos consistem de material particulado, oriundos de processos como a erosão e intemperismo trazidos ao corpo 
d'água pelo fluxo da drenagem da bacia, diretamente pela chuva ou por deposição seca (ESTEVES, 1998).

O intemperismo é o conjunto de processos de ordem física, química, e biológica que deriva uma partícula das rochas aflorantes na superfície da Terra. O intemperismo físico, pode ser caracterizado pela alteração mecânica das rochas e minerais, sendo resultado de um stress gerado por forças endógenas ou exógenas, que promovem a ruptura e um desagregamento dos minerais. Alterações deste tipo em que são mantidas a identidade e a composição original da rocha são classificadas como intemperismo físico. Nessas condições, os principais agentes que promovem este tipo de decomposição são as variações de temperatura (ciclos de congelamento e descongelamento) e pressão (compressão e descompressão). (TOLEDO; OLIVEIRA e MELFI, 2000)

No entanto, quando ocorre a decomposição da rocha com alteração química e mineralógica dos seus elementos, denomina-se o processo de intemperismo químico, resultando em minerais mais estáveis, sob novas condições ambientais. Os principais minerais presentes no manto de alteração são o quartzo, as micas parcialmente transformadas, os argilominerais e os oxido-hidróxidos de ferro e alumínio. Juntamente ao manto de alteração e produzida uma solução de lixiviação rica em elementos solúveis presentes na superfície terrestre, como sódio, cálcio, potássio, magnésio e em menor grau o silício. Outros elementos solúveis podem estar presentes em menores quantidades (TOLEDO; OLIVEIRA e MELFI, 2000).

O intemperismo biológico ocorre principalmente devido aos esforços mecânicos produzidos pelos vegetais através de suas raízes e de um ecossistema com micro-organismos atuantes. (TOLEDO; OLIVEIRA e MELFI, 2000)

Os sedimentos são encontrados em camadas na forma de partículas finamente divididas no fundo de rios, lagos, reservatórios, baias, estuários e oceanos. Esses consistem de maneira geral em vários minerais com granulação fina, media e grossa, incluindo argilas, silte e areia misturados com matéria orgânica, sendo que sua composição (mineral e orgânica) dependerá da Geologia e Biota local, enquanto o tamanho das partículas ou granulometria varia principalmente com as condições de sua origem (MANAHAN, 2000). 
Dentre os minerais que constituem os sedimentos destacam-se os argilominerais, por sua capacidade de incorporar elementos presentes no ambiente de deposição na rede cristalina, além da capacidade de transformação no meio sedimentar dependendo das características desses. Os argilominerais apresentam uma composição diversificada, sendo formadas por argilominerais, que são constituídos por silicatos, hidratos de alumínio com variados cátions $\left(\mathrm{K}^{+}, \mathrm{Mg}_{2}{ }^{+}, \mathrm{Fe}_{2}{ }^{+}, \mathrm{Fe}_{3}{ }^{+}, \mathrm{Na}^{+}, \mathrm{Ca}_{2}{ }^{+}, \mathrm{NH}_{4}{ }^{+}, \mathrm{H}^{+}\right)$ou aníons $\left(\mathrm{SO}_{4}{ }^{2-}, \mathrm{Cl}^{-}\right)$, hidróxidos $(\mathrm{Fe}, \mathrm{Al}, \mathrm{Mn})$ e partículas coloidais orgânicas e inorgânicas (POPP, 1998).

Os sedimentos desempenham o papel mais importante no esquema de poluição de sistemas de rios por metais pesados. Eles refletem a quantidade corrente do sistema aquático e podem ser usados para detectar a presença de contaminantes que não permanecem solúveis após o seu lançamento em águas superficiais. Mais do que isso, os sedimentos agem como carregadores e possíveis fontes de poluição, pois os metais pesados não são permanentemente fixados por eles e podem ser redispostos na água, em decorrência de mudança nas condições ambientais tais como: potencial hidrogeniônico; potencial redox ou presença de quelantes orgânicos. As propriedades de acúmulo e de redisposição de espécies nos sedimentos os qualificam como de extrema importância em estudos de impacto ambiental, pois registram, em caráter mais permanente, os efeitos de contaminação (FÖRSTNER et al.,1983; MOZETO, 1996).

\subsubsection{Granulometria}

Análise granulométrica dos solos ou simplesmente Granulometria é o processo laboratorial que visa definir em determinadas faixas, pré-estabelecidas, sobre o tamanho dos grãos e a percentagem em peso que cada fração possui em relação à massa total da amostra em análise. De uma forma geral, a parte sólida dos solos é composta por um grande número de partículas que possuem diferentes dimensões.

A distribuição granulométrica é representada através de uma curva que possibilita assim a determinação de suas características físicas. As frações granulométricas são divididas de acordo com as dimensões das partículas compreendidas entre determinado limite convencional. Nesse sentido, na Figura 2 estão apresentadas as classificações adotadas pela 
ASTM (American Society for Testing Materials), AASHTO (American Association for State Highway and Transportation Officials), ABNT (Associação Brasileira de Normas Técnicas) e MIT (Massachusetts Institute of Technology) (TAVARES, PINHEIROS e SOARES, 2006). Nesta pesquisa foi adotada a classificação segundo a ABNT.

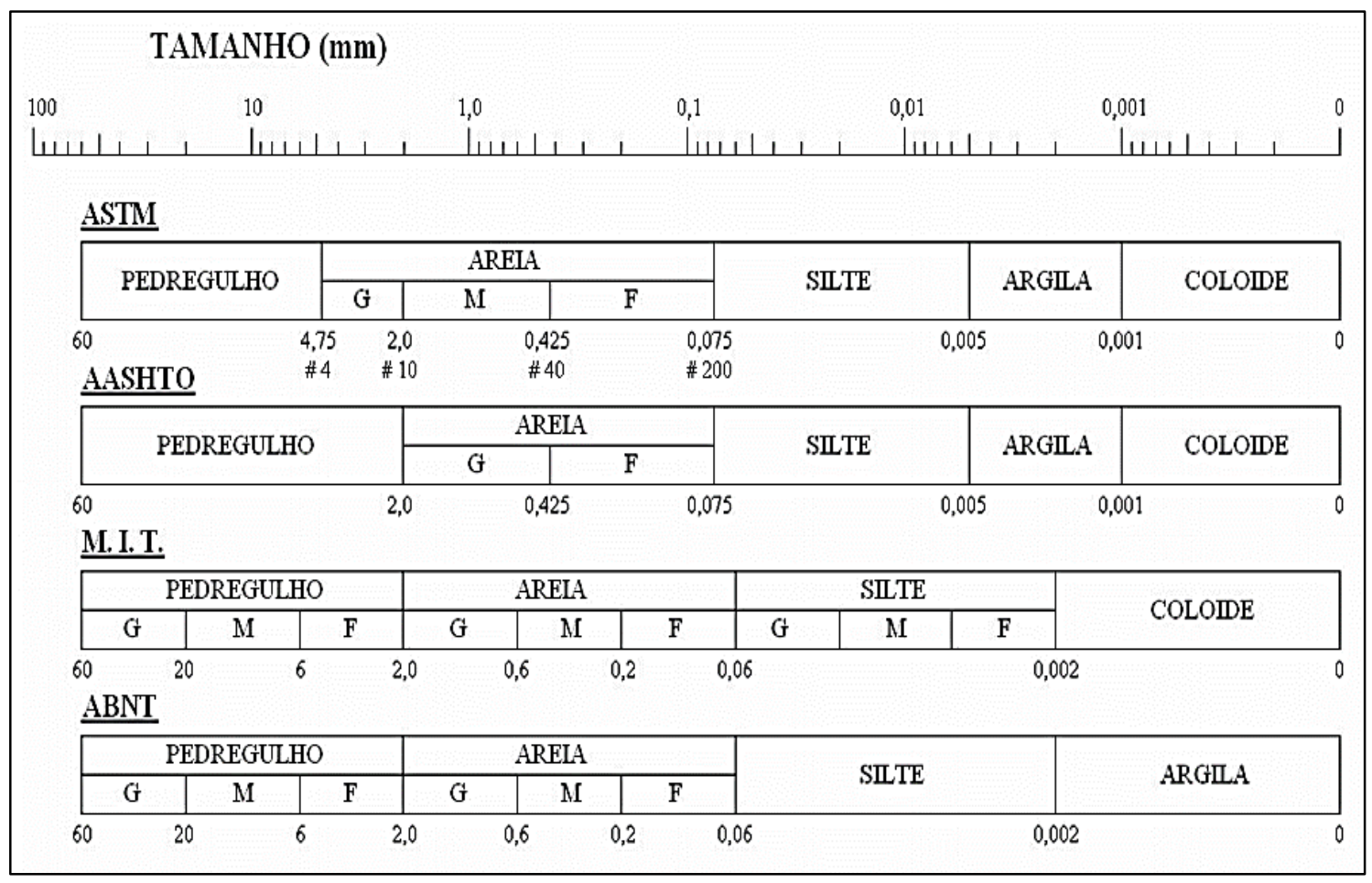

Figura 2- Escalas granulométricas adotadas pelas ASTM, AASHTO, MIT e ABNT. Fonte: Adaptado de TAVARES, PINHEIROS e SOARES (2006)

Segundo a ABNT para a análise granulométrica, busca os aspectos, para efeito do tamanho das partículas sobre a acumulação de algumas espécies metálicas. Os sedimentos contaminados frequentemente mostram um enriquecimento similar de metais nas frações mais finas, (silte e argila), contudo, existem situações nas quais os metais contaminantes atingem as frações mais grossas do solo. Os resultados obtidos por Padmalal e colaboradores (1997 apud GARLIPP, 2006), mostram a importância de se analisar a fração fina para a obtenção da concentração dos metais traço. 


\subsubsection{Transporte de Sedimentos}

Os processos hidrossedimentológicos estão intimamente vinculados ao ciclo hidrológico e compreendem as etapas de deslocamento, transporte e deposição de partículas sólidas presentes na superfície da bacia hidrográfica (SILVA; CAMARGO e CERETTA, 2003).

No ciclo hidrossedimentológico, os materiais resultantes do processo de erosão acabam sendo transportados principalmente pela ação das águas de escoamento superficial, sendo tal transporte influenciado pelas condições topográficas do local e pela granulometria dos materiais carreados. O transporte desse material arrancado se dá por fluxo de massa, podendo ocorrer na forma de rolamento e arraste da partícula, ou então por suspensão (VESTANA, 2008).

Segundo Carvalho (2008), o processo de deposição ocorre quando a força do escoamento se reduz até a condição de não poder continuar a deslocar a partícula. O depósito dos sedimentos geralmente se dá em locais relativamente mais baixos, podendo ocorrer em depressões naturais do terreno ou mesmo em encostas de declividade mais suave. Além disso, o material pode adentrar a rede de drenagem, sendo transportado pelos cursos d'água até o oceano ou ficar retido em reservatórios, nas margens de cheia, em planícies de inundação, deltas e estuários. De acordo com Foster (1982), há a possibilidade de os sedimentos transportados poderem ainda, serem depositados em determinados locais apenas temporariamente, e após um evento subsequente ressuspendê-los e movimentá-los novamente através do sistema de transporte.

Segundo Carvalho (2008), os sedimentos que chegam ao curso d'água apresentam diversas formas, tamanhos e pesos, sendo submetidos a um processo de transporte diferenciado, de acordo com as condições do local e do escoamento. De acordo com o autor, o transporte nos canais pode ocorrer de três maneiras: 
i. Carga sólida de arrasto - são as partículas de sedimento que rolam ou escorregam longitudinalmente no curso d'água. As partículas estão em contato com o leito praticamente todo o tempo.

ii. Carga sólida saltante - são as partículas que pulam ao longo do curso d'água por efeito da correnteza ou devido ao impacto de outras partículas.

iii. Carga sólida em suspensão - são as partículas que estão suportadas pelas componentes verticais das velocidades do fluxo turbulento, enquanto estão sendo transportadas pelas componentes horizontais dessas velocidades, sendo pequenas suficientemente para permanecerem em suspensão.

A figura 3 ilustra os processos descritos por Carvalho (2008), apresentando as condições e forma de ocorrência do transporte de sedimentos em um corpo hídrico.

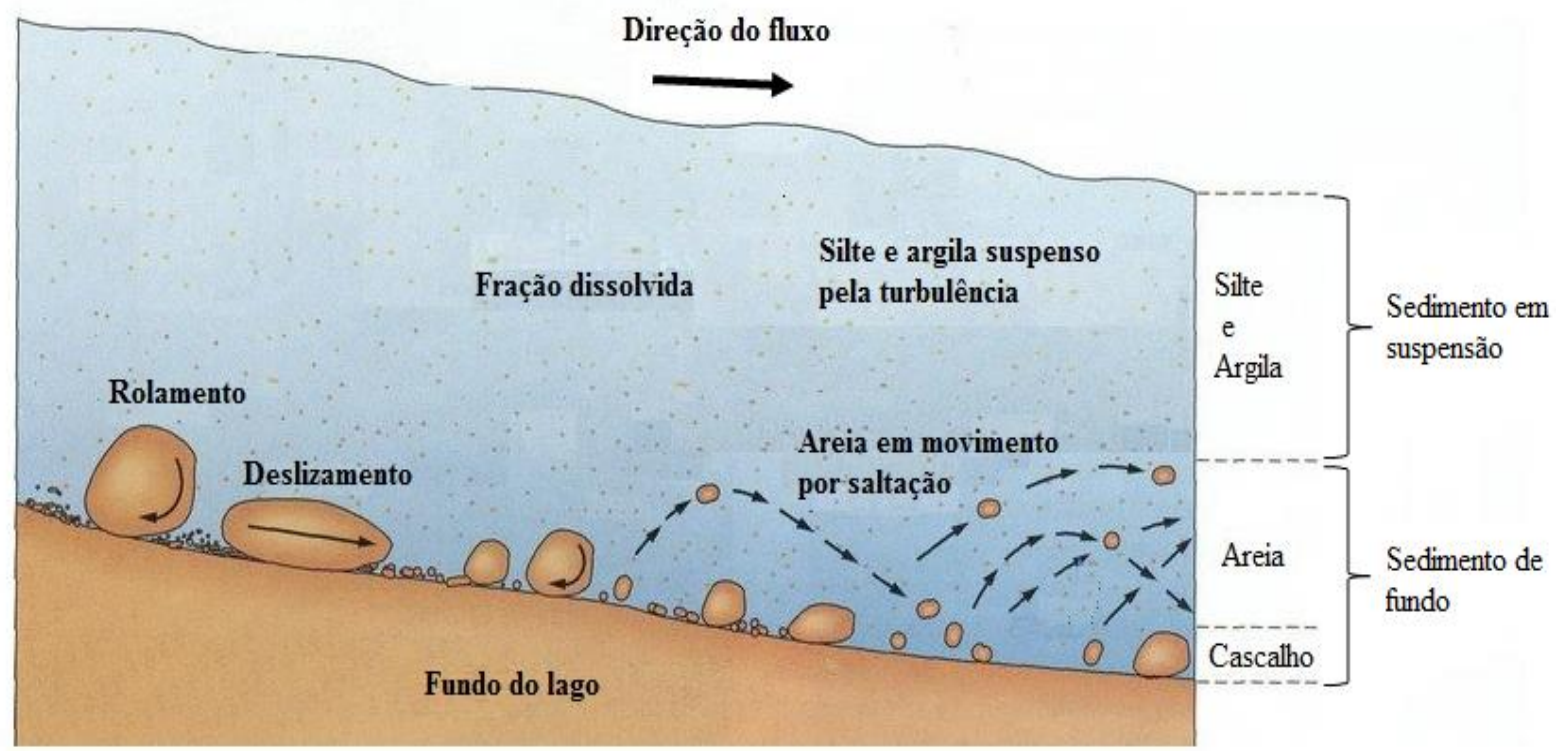

Figura 3 - Modos de transporte de partículas nos corpos hídricos

Fonte: Adaptado de Plummer, Mcgeary e Carlson (2005)

Os materiais de arraste e saltação constituem o material do leito e têm seu movimento governado pela capacidade de transporte do escoamento. Por outro lado, o material em suspensão, compreendendo as partículas de granulometria reduzida (silte e argila), move-se aproximadamente na mesma velocidade da corrente (NORDIN e McQUIVEY, 1971). 
Dentre o material particulado carregado em suspensão, os sedimentos mais finos, que compreendem as frações das classes silte e argila, possuem um padrão da velocidade de deposição distinto com relação a outros grãos maiores, sendo influenciado por fatores intrínsecos como a salinidade, a própria concentração de sedimentos e a matéria orgânica na coluna d' água, além da própria composição mineralógica (SOLOMONS e FORSTNER, 1984; KRONE, 1962; LICK e ZIEGLER, 1992).

Ward e Trimble (1995) afirmam que a carga em suspensão pode representar mais de 90\% do material total transportado. As partículas de granulometria maior, como as areias e cascalhos, são roladas, deslizadas ou saltam ao longo do leito dos rios. A porcentagem das partículas em suspensão, também é descrita e considerada por Carvalho (2008), e é predominantemente maior que a do fundo no alto curso (Apresenta valores com porcentagem equivalente a $90 \%$ a $95 \%)$.

A proporção entre os materiais dissolvidos e materiais particulados varia entre os diferentes cursos d'água. Segundo Christofoletti (1981), para os rios brasileiros, a carga particulada geralmente é bem maior que a carga dissolvida. Além disso, o autor discorre que a composição química das águas fluviais varia de acordo com a litologia, a vegetação e a utilização do solo da bacia hidrográfica.

O somatório das parcelas de sedimentos carregadas em suspensão e formas de leito com a carga em solução corresponde à carga total de sedimentos transportada pelo curso d'água. A carga total de sedimentos é, em última análise, composta por materiais fornecidos tanto por processos químicos, por processos pluviais e por movimentos de arraste de massa nas vertentes.

Segundo Silva, Schulz e Camargo (2003), é importante ressaltar que a maior parte dessas considerações é válida principalmente para bacias com pouco índice de degradação, pois se houver superexploração do solo e dos recursos hídricos de uma bacia, seu regime fuvial, bem como o regime hidrossedimentológico, podem apresentar-se completamente distorcidos em relação a seu regime natural. 


\subsubsection{Sedimentos Lacustres}

Os sedimentos originados nos processos de intemperismo e erosão são normalmente transportados pelos rios tendo como destino final os oceanos. Em ambientes que se localizam no interior dos continentes, como os lagos, reservatórios de barramentos e planícies de inundação são responsáveis pelo estoque de parte desses sedimentos carreados pelo fluxo hídrico. Geralmente os reservatórios tem por finalidade o abastecimento de águe e o fornecimento de energia para as populações, porém acabam se tornando barreiras artificiais para a deposição de água e sedimentos (SALOMONS e BRILS, 2004).

Os sedimentos podem ser considerados com o resultado da integração de todos os processos que ocorrem em um ecossistema aquático. Sua composição química e biológica, guarda a evolução histórica do ecossistema aquático e sistemas terrestres adjacentes, além de sua importância na avaliação da intensidade e formas de impactos sofridos por esses ambientes.

As camadas dos sedimentos lacustres formadas em períodos da evolução do ecossistema refletem a composição química e biológica em diferentes fases do processo, sendo possível, a partir dos perfis de sedimentos, interpretar o desenvolvimento histórico e alterações, tanto no ambiente como nas comunidades. Devido as suas propriedades, os sedimentos de ecossistemas lacustres funcionam como um banco de dados, tendo significativa importância em estudos de avaliação ambiental. Para tanto, as amostras devem ser coletadas sob a forma de perfis verticais (CORE), a amostragem deve colher perfis não perturbados, ou seja, com suas camadas sedimentares preservadas (ESTEVES, 1998).

Tais ecossistemas propiciam condições ideias para a determinação da concentração de metais, como Zinco e Níquel presente na coluna sedimentar, pois são ambientes de deposição com pouca perturbação, onde predominam sedimentos com granulação fina. 


\subsection{Qualidade dos sedimentos urbanos frente aos processos de urbanização}

As modificações antrópicas em áreas urbanas podem implicar em diversos passivos ambientais no aspecto hidrológico, onde a qualidade da água, seja ela superficial ou subterrânea, estará sujeita a degradação. Poleto e Castilhos (2008) trazem como as principais implicações a perda de qualidade dos recursos hídricos o lançamento de efluentes sejam eles domiciliares, industriais ou provenientes das atividades agrícolas, sendo considerada sua deposição no corpo hídrico na forma líquida e sólida ou ainda que possam infiltrar através do solo. A impermeabilização do solo contribui para o carreamento dos poluentes através do escoamento superficial. Substâncias nocivas à saúde do meio ambiente podem estar agregadas ao sedimento escoado e conter elementos como metais, hidrocarbonetos e organoclorados, consequentemente podem levar a contaminação o corpo d'água receptor (METRE; MAHLER, 2003).

Em um ambiente urbano ocorre uma grande e complexa produção e mescla de poluentes que podem ser advindos de fontes no próprio local, ou mesmo importadas de outras áreas próximas ou ainda muito afastadas, como pode ser observado na Figura 4, que apresenta algumas das fontes de produção de sedimentos e contaminação a qual estão expostos no carreamento até os corpos d'água.

Muitos estudos ao redor do mundo têm identificado as principais fontes de contaminantes associados a locais com intenso tráfego veicular (Charlesworth et al., 2003). Segundo Adachi \& Tainosho (2005), é de conhecimento que os sedimentos provenientes de ruas e estradas são fontes de metais e outros contaminantes no meio ambiente urbano. Além disso, em áreas urbanas, o fluxo de veículos por áreas impermeáveis tende a concentrar os metais que deverão ser transportados para a rede de drenagem durante os eventos de chuva através do escoamento superficial. 


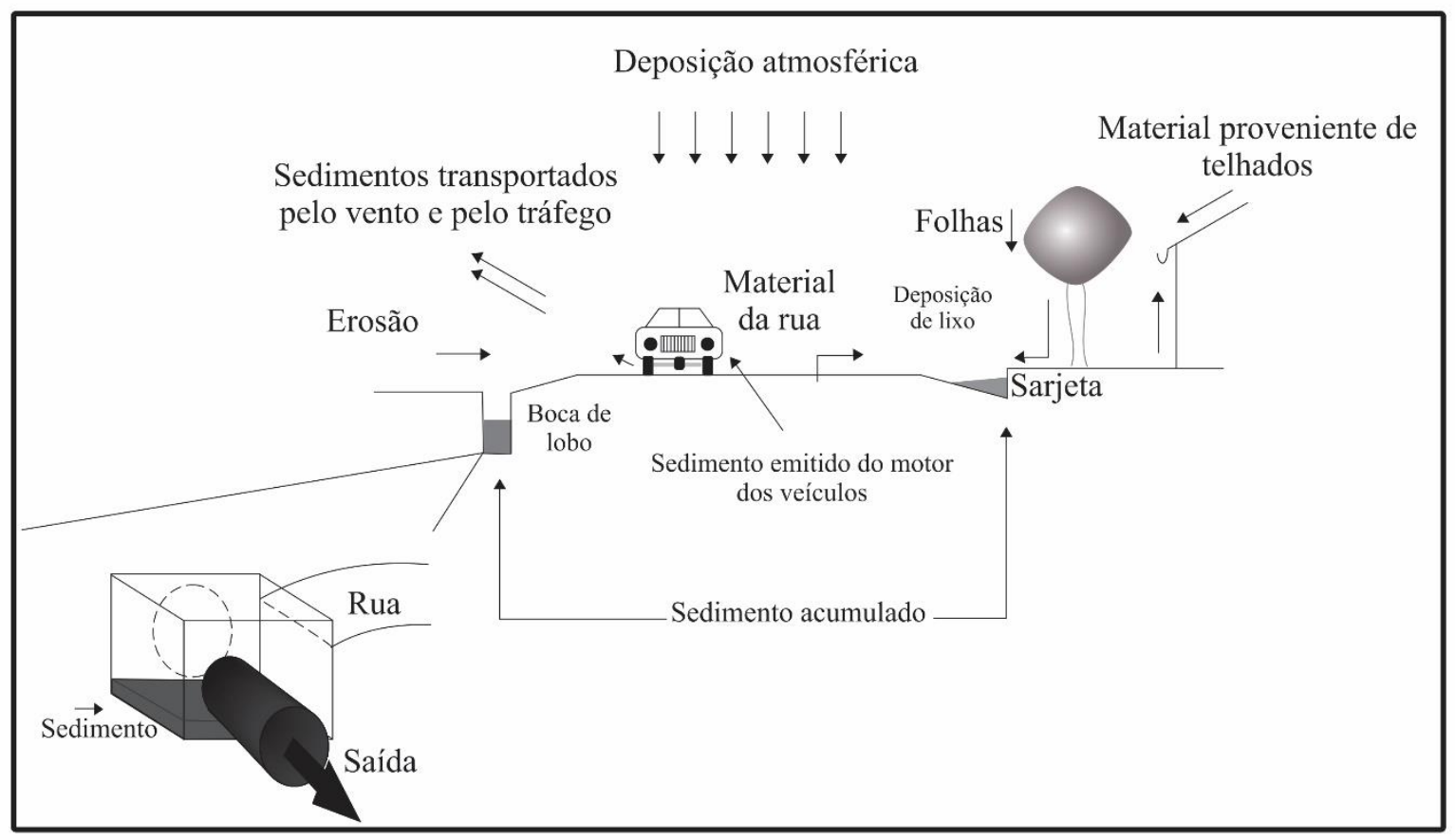

Figura 4 - Origem e destinação dos sedimentos em ambientes urbanos. Fonte: TAYLOR (2007) e POLETO (2008)

Segundo Elder (1988), os metais podem ser encontrados em uma diversidade de formas e compartimentos biogeoquímicos, sendo íons hidratados ou livres, coloides, precipitados, adsorvidos a fase sólida e na forma de complexos de coordenação com diferentes ligantes orgânicos e inorgânicos. Segundo Pardo et al. (2004), os sedimentos contaminados são os maiores contribuintes para a degradação dos ecossistemas lacustre. É de fundamental importância que se conheça sobre o seu comportamento e toxicidade, para atuar na preservação dos recursos hídricos.

Para Muller, Grimmer e Böhnke (1977), os contaminantes em ecossistemas aquáticos podem ser investigados analisando parâmetros como a água, partículas de sedimentos em suspensão, ou então os sedimentos. Lemes (2001) diz que por se tratarem de compostos orgânicos e inorgânicos, os sedimentos de um corpo d'água estão propensos a céleres trocas em sua composição com a coluna de água, caracterizando uma importante ferramenta no meio de avaliar os níveis de poluição presente no ecossistema. 
Os elementos traço ou então denominados "metais pesados", estão presente no ambiente natural em concentrações geralmente baixas, mas podem ser intensificadas por atividades antropogênicas e têm colaborado significativamente para a elevação da concentração no meio ambiente (SINGH et al., 2005; SKJELKVALE et al., 2001). Segundo Baird (2002), os elementos traço possuem sua densidade alta quando comparados com outros materiais, se caracterizam muitas vezes por causar riscos à saúde humana e se agregam as partículas de sedimentos ou solo em sua deposição final. Ademais, Skjelkvale et al. (2001) relatam que os condicionantes da bacia hidrográfica e corpos d'água são determinantes para a flexibilidade e a disponibilidade destes elementos traços na água.

É possível observar que, quando um metal-traço entra em um corpo d'água, ele está sujeito a inúmeros processos físicos, químicos e biológicos controlados pela hidrodinâmica local, que podem resultar na mudança da sua partição geoquímica, estabelecendo-se um equilíbrio entre as fases dissolvida e particulada. Assim, este material particulado pode servir como fonte de metais dissolvidos para coluna d'água, ou como removedor de metais dissolvidos por adsorção no material particulado em suspensão.

No material particulado a adsorção dos metais geralmente é seguida pela floculação, sedimentação e deposição do sedimento. Os sedimentos são reservatórios dinâmicos dentro de um ecossistema, e também podem estar sujeitos a uma variedade de processos físicos, químicos e biológicos, responsáveis pela reciclagem desses elementos na coluna d'água (CABELOGARCÍA e PREGO, 2003).

Segundo Cabelo-García e Prego (2003), os metais podem se adsorver na superfície dos colóides, tanto nos orgânicos como nos inorgânicos por meio das forças eletrostáticas, estando portanto, envolvidos na adsorção não específica. Na fase dissolvida, os colóides dependendo do equilíbrio com a fase particulada, podem receber contribuições importantes de metais oriundos das regiões entre a coluna de água e sedimentos. Na fração dissolvida, o metal pode circular e sofrer complexação por ligantes orgânicos, como a matéria orgânica dissolvida, complexação por ligantes inorgânicos, como carbonatos, hidroxila, sulfetos, entre outros. 


\subsection{Contaminação dos sedimentos por metais pesados}

Os metais pesados ocorrem naturalmente nos solos. Sua composição depende, principalmente, do material de origem em seu processo de formação, composição e proporção dos componentes de sua fase sólida (FADIGAS et al., 2002).

As regiões industriais e urbanas estão se deparando com contaminação de solos por metais pesados e vem trazendo agravantes, como os passivos ambientais (HANESH e SCHOLGER, 2002). No entanto, a preocupação com o meio ambiente natural não se fez presente durante muitos anos, tendo como resultado problemas ambientais de grandes dimensões (GÓIS, FARIAS e ARAUJO, 2008).

Nas últimas décadas acentuou-se a preocupação quanto à contaminação e poluição do solo e das águas superficiais e subterrâneas devido à grande expansão urbana e industrial (MEURER, RHEINHEIMER e BISSANI, 2010).

Os elementos-traço estão presentes naturalmente em solos e nos recursos hídricos, sendo superficial ou subterrâneo, mesmo que não exista a perturbação antrópica inferindo no ambiente, o aumento em sua concentração pode ser ocasionado tanto por processos naturais quanto por atividades antrópicas (GUILHERME et al., 2005).

Segundo Alloway (1990) diversos estudos de metais pesados em ecossistemas indicaram que grandes áreas próximas a complexos urbanos, metalúrgicas e rodovias apresentam altas concentrações destes elementos. Metais acumulados nos solos esgotam-se lentamente por processos de absorção pelas plantas, lixiviação ou erosão (KABATA-PENDIAS e PENSIAS, 2001). 


\subsection{Matéria Orgânica Presente nos Sedimentos (M.O.)}

A matéria orgânica presente nos sedimentos e solos, consiste de uma mistura de diferentes produtos em vários estágios de decomposição. Faz referência a todos os compostos que contêm carbono orgânico, incluindo os microrganismos vivos, mortos e os produtos da decomposição realizadas por estes (SILVA, CAMARGO e CERETTA, 2004).

A matéria orgânica de origem natural, é derivada principalmente de plantas e/ou resíduos microbianos e pode ser produzida (“in situ”) dentro de um corpo d'água. Manguezais e Banhados são exemplos, pois nesses ambientes a camada superior dos sedimentos de fundo é composta quase inteiramente de matéria orgânica (M.O.) em diversos estágios de decomposição e o material transfere-se para a coluna de água em forma de partículas ou colóides. Outros corpos d'água como rios, lagos e oceanos, também permitem o crescimento das plantas e animais aquáticos, mas esse aporte é menos significativo, sendo a maior parte da M.O. advinda do ambiente terrestre e carreada através das águas pluviais.

Além das fontes naturais, são importantes os aportes antrópicos que contribuem para a matéria orgânica na água e no solo, na forma de resíduos como esgotos domésticos ou efluentes industriais, sem prévio tratamento, ou de compostos orgânicos de origem agrícola (VANLOON e DUFFY, 2005). A Figura 5 demostra o fluxo da matéria orgânica natural e antrópica nos diversos compartimentos ambientais. 


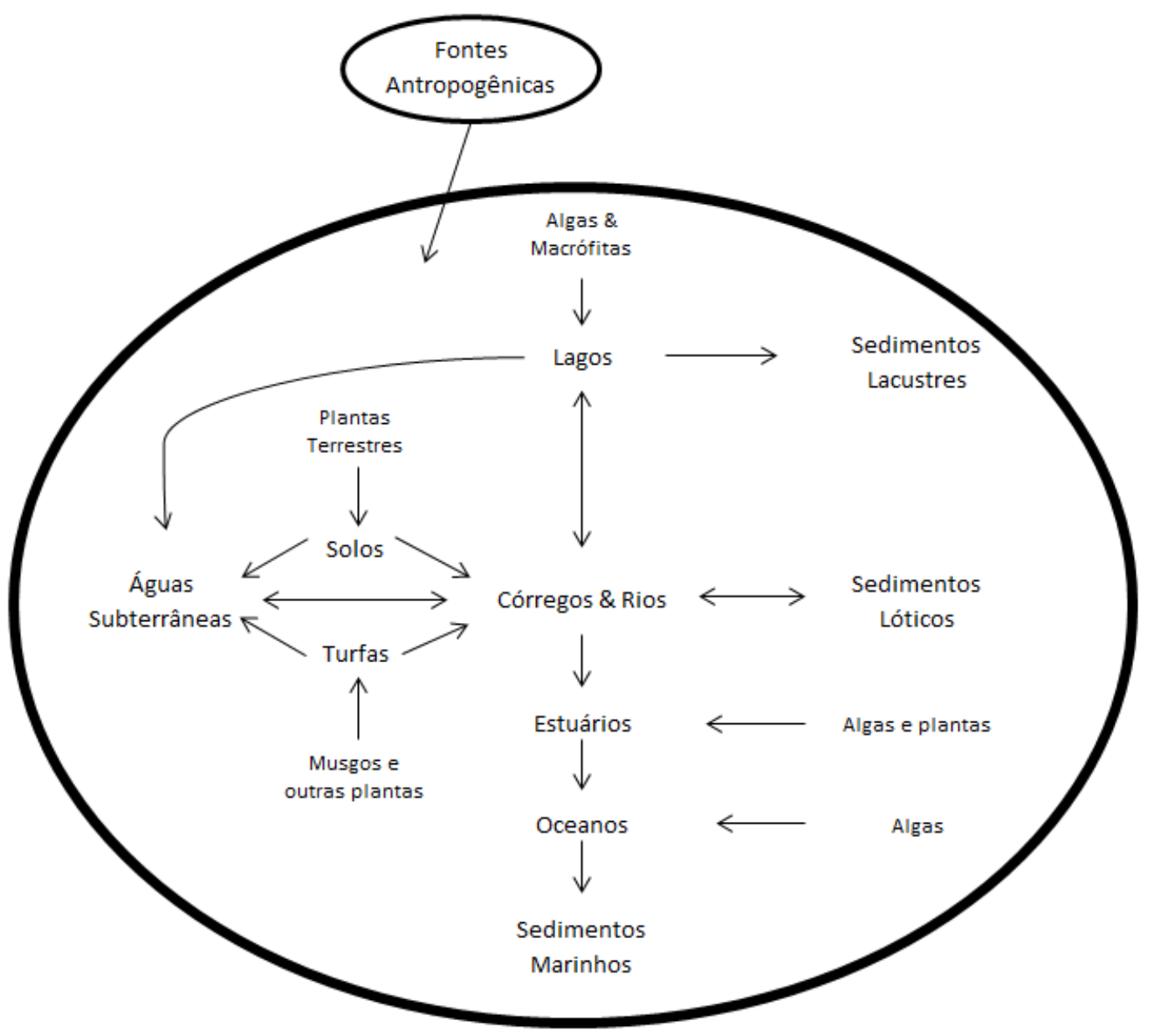

Figura 5 - Diagrama do fluxo ambiental da matéria orgânica.

Fonte: Adaptado de: CARDOSO (2011)

Superfícies orgânicas ou cobertas por matérias orgânicas possuem grupos funcionais que podem atuar como sítios coordenadores aos quais os cátions metálicos podem se ligar (MARIANI, 2006).

Segundo Singer (1977 apud FÖRSTNER e WITTMANN 1981), as substâncias orgânicas dissolvidas são capazes de:

- Complexar elementos metálicos e aumentar a solubilidade destes;

- Alterar a distribuição entre as formas, oxidada e reduzida das espécies metálicas;

- Reduzir a toxicidade das espécies metálicas e alterar a disponibilidade para a vida aquática; 
- Influenciar a extensão para o qual as espécies metálicas são adsorvidas na matéria suspensa;

- Afetar a estabilidade das espécies metálicas tal contaminante coloidal.

A matéria orgânica possui a capacidade de adsorção para algumas espécies metálicas de massa atômica elevada. Essa afinidade pode tanto concentrar espécies metálicas no ambiente, impactando-o, quanto pode ser empregada na remoção dessas espécies metálicas em ambientes impactados. Uma importante propriedade física da matéria orgânica está associada à textura fina dos solos, contendo geralmente uma porcentagem natural de material húmico derivado de transformações biológicas de plantas e detritos de animais. O material húmico pode estar presente como uma discreta partícula ou como uma camada em partículas de argila, pois ele aumenta a afinidade do solo com metais (FORSTNER e WITTMANN, 1981).

A natureza molecular dos compostos orgânicos também influencia nas formas de sorção aos cátions, substâncias orgânicas de alto peso molecular podem se ligar fortemente aos cátions metálicos, tornando-os inertes, enquanto que alguns compostos de baixo peso molecular, como os ácidos húmicos, podem aumentar a solubilidade de íons potencialmente perigosos (MALLMANN, 2009).

Segundo Franchi (2004), as substâncias húmicas são produtos intermediários no ciclo de decomposição da matéria orgânica e são oriundas da ação dos microrganismos existentes no solo (oxidação biológica). Apresentam-se como compostos de coloração amarela a preta, de alto peso molecular, podendo ser encontrada em rios, lagos, oceanos e em seus sedimentos e solo.

A decomposição da matéria orgânica associada aos sedimentos provoca modificações que influenciam no ciclo biogeoquímico de vários elementos, determinando a forma pela qual os mesmos encontram-se ali presentes. Essas modificações consistem de reações diagenéticas capazes de produzir decomposição de matéria orgânica reduzida, material húmico e quelação de metais (BERNER e BERNER, 1996).

A determinação dos teores de matéria orgânica em amostras ambientais tem sido utilizada em diversos trabalhos no campo de atividade científica, em áreas como: sedimentos, solos e água. A importância dessa determinação consiste, por exemplo, que a matéria orgânica 
presente em águas subterrâneas pode ser nociva à qualidade dessas águas, enquanto que quando transportada pelos rios ou presente em águas estuarinas é de importância vital para a cadeia alimentar. Para os solos esse parâmetro tem importância pedológica no que diz respeito à fertilidade química desses ambientes, enquanto que em sedimentos é indicativa dos processos geoquímicos associados ao ambiente geológico considerado (DIAS, 2004).

\section{7. Índice de geoacumulação - Igeo}

Os sedimentos são produtos de degradação em grande escala, tanto física quanto química, e é necessário obter-se o máximo de informações sobre sua origem, suas características mineralógicas e físico-químicas, bem como os fatores ambientais que controlam os processos de intemperismo, transporte e deposição (PROHIC e JURACIC, 1989). A determinação de elementos traço, sobretudo os metais tóxicos, é um dos meios mais apropriados para se avaliar o grau de impacto derivada das ações antropogênicas em uma determinada bacia hidrográfica (ARMANNSSON, BURTON e JONES, 1985; ROY e CRAWFORD, 1984).

O Índice de Geoacumulação - I.Geo é uma medida referente a quantidade da poluição causada por metais nos sedimentos aquáticos. Este índice estabelece a relação entre os teores de metais encontrados na região em análise e um valor referencial equivalente à média mundial para metais associados às argilas (SOARES et al., 2004)

Para a avaliação da intensidade da contaminação do sedimento pode-se empregar o índice de geoacumulação - I.Geo., proposto por Müller em 1979 (apud in IAEA TEC DOC, 2003). Este índice estabelece a relação entre os teores de metais encontrados na região em análise e um valor referencial equivalente à média mundial para metais associados às argilas. O valor obtido permite classificar os níveis de enriquecimento dos metais com intensidades progressivas de contaminação.

Os níveis de enriquecimento são classificados em sete classes distintas, que variam de 0 a 6 e estão relacionadas com o grau crescente de contaminação, (Tabela 1). O valor mais alto corresponde a um enriquecimento de aproximadamente 100 vezes em relação ao nível de referência. 
Tabela 1 - Classificação dos Igeo

\begin{tabular}{lcc}
\hline \multicolumn{1}{c}{ Classificação } & Classes do IGEO & $\begin{array}{c}\text { Intervalos do } \\
\text { IGEO }\end{array}$ \\
\hline Extremamente Poluído & 6 & (Maior que 5) \\
Fortemente à Extremamente Poluído & 5 & $(4-5)$ \\
Fortemente Poluído & 4 & $(3-4)$ \\
Moderadamente à Fortemente Poluído & 3 & $(2-3)$ \\
Moderadamente Poluído & 2 & $(1-2)$ \\
Não Poluído à Moderadamente Poluído & 1 & $(0-1)$ \\
Praticamente Não Poluído & 0 & (Menor que 0) \\
\hline
\end{tabular}

Fonte: Müller (apud in IAEA TEC DOC, 2003).

O cálculo do IGeo é realizado e voltado para às concentrações obtidas na fração silte/argila $(<0,062 \mathrm{~mm})$. Portanto $C_{a}$ é a concentração do elemento na fração silte mais argila do sedimento. Este procedimento possibilitou a melhor representação das contribuições litológicas das áreas de estudo.

O índice de geoacumulação é calculado pela equação 1:

$$
\text { Igeo }=\log _{2} \times \frac{C_{a}}{1,5 \times C_{p}}
$$

Equação 1:

Em que:

- $\mathrm{C}_{\mathrm{a}}$ : concentração do elemento na fração argila do sedimento (mg.kg-1);

- $\mathrm{C}_{\mathrm{p}}$ : concentração do elemento no padrão de referência em mg.kg-1, (folhelho médio ou crosta);

- 1,5: fator de correção para possíveis variações no padrão de referência causado por diferenças litológicas.

Os intervalos do Igeo variam de 0 a 6 , e estão relacionados com o grau crescente de contaminação, onde o valor mais elevado corresponde a um enriquecimento de aproximadamente 100 vezes em relação ao nível de background. 


\subsection{Digestão da Amostra ou Abertura da amostra}

A primeira etapa de uma análise química consiste em submeter a amostra a um tratamento adequado, visando a sua preparação para progredir nas etapas que formam uma análise química (ARRUDA e SANTELLI, 1997).

A quantidade total de metais presentes no sedimento altera-se bastante em função do material de origem, características e o sistema de manejo a que ele foi submetido, do tipo de metal, de outros elementos presentes, entre outros fatores. A determinação dos teores totais de elementos em sedimentos é uma importante ferramenta para monitorar a poluição ambiental.

A Agência de Proteção Ambiental dos Estados Unidos da América (US-EPA) possui métodos muito utilizados para a digestão de amostras de solos, sedimentos e resíduos, sendo o procedimento de digestão, seguindo o método da EPA 3050, se dá pelo ataque por ácido nítrico e água oxigenada, liberando os metais ligados à matéria orgânica, óxidos e outras frações minerais, com exceção da silicatada. Segundo Abreu, Andrade e Falcão (2006), sua principal desvantagem é o tempo muito longo para completar a digestão, podendo provocar riscos de perdas e contaminações.

Outro método bastante eficiente é o conhecido como Água Régia, mistura fortemente oxidante e tem a capacidade de dissolver até mesmo metais nobres, porém não dissolve totalmente silicatos. Oliveira, Tavares e Mahler (2008) estudando a eficiência dos métodos de análise do teor total de metais (Água Régia, EPA - 3051 e 3052), concluíram ser a "Água Régia" a mais apropriada. No entanto, cabe ressaltar que o método EPA 3050 é um método oficial, reconhecido e amplamente utilizado nos Estados Unidos e por muitos órgãos ambientais do mundo. No Brasil, vários Estados utilizam esse método para poder comparar os teores determinados metais. 


\subsection{Análise Espectrometria de Emissão com Plasma Acoplado Indutivamente (ICP OES)}

Análise através da técnica de Espectrometria de Emissão Óptica com Plasma Acoplado Indutivamente (ICP OES) surgiu na década de 70 e foi inicialmente desenvolvida como alternativa à Espectrometria de Absorção Atômica (EAA) e outras técnicas como Espectrometria de Emissão Atômica por arco e centelha. O ICP OES, comparado à EAA, por exemplo, tem somente cerca de metade de sua história comercial e um décimo ou menos de número de unidades em operação no mundo. Apesar disso, os aperfeiçoamentos do instrumento e novas aplicações para o plasma estão ocorrendo em velocidade mais elevada (PETRY, 2005).

Esta técnica é tradicionalmente utilizada para a análise de solos e sedimentos. A técnica de ICP OES tem sido aplicada frequentemente, pois oferece uma grande série de vantagens, como por exemplo, a análise multi-elementar simultânea, uma alta sensibilidade e precisão nos resultados, sempre com rapidez na execução da técnica. Está técnica permite ainda, determinar desde as baixas concentração de metais e não-metais até as maiores concentrações.

Segundo Harper e Oliveira (2006) e Medeiros (2009), o plasma é uma fonte que produz alta temperatura, onde minimiza efeitos de matriz e produz uma sensibilidade adequada para maioria dos metais e não-metais, em diferentes faixas de concentração. Essa técnica de análise, é aplicável e permissível para a determinação de sólidos, líquidos e gases e tem a capacidade de produzir resultados rápidos e úteis para controle de processos, tais como, a contaminação de sedimentos, solo, entre outros.

\subsection{Relação dos sedimentos com o nível de poluição (Background)}

Os sedimentos são uma referência à condição de saúde de um sistema aquático, pois estes atuam como um depósito para acumulação dos contaminantes. O estudo das colunas sedimentares fornece o registro histórico das substâncias oriundas de atividades antrópicas, ou não, que se desenvolveram na bacia hidrográfica ao longo dos últimos anos (MÜLLER, GRIMMER e BÖHNKE, 1977), seguindo o princípio da superposição das camadas geológicas, 
pelo qual as camadas sedimentares são depositadas em uma sequência de tempo, com o estrato mais antigo no fundo e o mais novo no topo.

Para validar os estudos é necessária a identificação dos níveis de base desses elementos na área. Essas amostras, denominadas background, possibilitam inferir sobre o enriquecimento de sedimentos por poluentes a partir da determinação de seus níveis naturais, e podem ser obtidas em amostras da base de testemunhos sedimentares lacustres, ou em áreas vegetadas preservadas na área em que se realizará o estudo. A concentração natural dos elementos no solo, também chamada de fundo geoquímico local, é derivada principalmente do material de origem da área, associado aos processos que atuaram na sua formação geoquímica (MALLMANN, 2009).

Segundo Poleto (2007), para a avaliação dos níveis de metais encontrados nas áreas de estudo é muito importante a utilização de valores de background locais. Estes podem ser obtidos através de amostras compostas coletadas em áreas vegetadas sem alterações antrópicas ou do fundo de lagos, ou seja, áreas que não foram afetadas por descargas de contaminantes e, portanto, preservam as características originais do local (OMEE, 1993). As concentrações totais de metais contidas nesses sedimentos possibilitam uma informação importante sobre os níveis originais (Buykx et al., 2000). A utilização de concentrações dos backgrounds pode ser útil tanto para comparações entre os resultados de estudos em áreas degradadas, quanto para a tomada de decisões quanto a remediação de áreas contaminadas ou potencialmente contaminadas.

Neste contexto, no estudo das colunas sedimentares torna possível a identificação da variação cronológica das atividades antrópicas desenvolvidas em uma bacia, bem como mensurar seus impactos sobre o ecossistema aquático. 


\section{CARACTERIZAÇÃo dA ÁREA dE ESTUDO}

\subsection{Interferências antropogênicas na Represa Mãe d’Água}

Segundo Fujimoto (2001), a represa Mãe d’Água foi inaugurada em 1962 pelo Departamento Nacional de Obras e Saneamento e toda água drenada pela bacia tem como exutório a represa. O intuído da construção da barragem, visava suprir as necessidades do Instituto de Pesquisas Hidráulicas (IPH) e as granjas experimentais da Faculdade de Agronomia, ambos com sede na Universidade Federal do Rio Grande do Sul.

No presente momento a área de estudo encontra-se predominantemente caracterizada por uma ocupação residencial, dominando a população advinda de fontes difusas. Conforme os estudos realizados por Poleto (2007), houve no passado uma importante indústria metalúrgica, onde atraiu migrantes pioneiros da Bacia do Lago Mãe d'água. A metalúrgica Heraud, que segundo Escobar (2014), teve como principal demanda o fornecimento dos componentes metálicos para a travessia Getúlio Vargas (Ponto do Gauíba). Tal fato histórico traz considerações relevantes no âmbito da geocronologia sobre a concentração dos metais traço presente nos sedimentos de base, notando que Bonetto (2014) data o decaimento da produção metalúrgica no final da década de 1970.

Segundo Fujimoto (2001), embasado em registros históricos advindos de moradores e técnicos envolvidos na obra, e na posse de fotografias reconstruiu o panorama ambiental anterior a construção da Barragem, com matas ciliares preservadas, fauna abundante e pequenas bacias de acumulação construídas pelos próprios moradores. Foi verificado também que os primeiros loteamentos aprovados pelo poder municipal para a área da bacia foram da década de 1950. A construção e implementação do Campus do Vale da UFRGS, iniciou-se na década de 1970, e a melhoria da infraestrutura urbana e viária.

Na Figura 6 é possível verificar a alta concentração da matéria orgânica presente no lago do barramento, sendo perceptível a entrada dos esgotos, pois há a formação grande quantidade de "espumas" na cor branca após o vertedor da barragem juntamente com a coloração variável em tons de cinza e preto da água (influencia sazonal). 


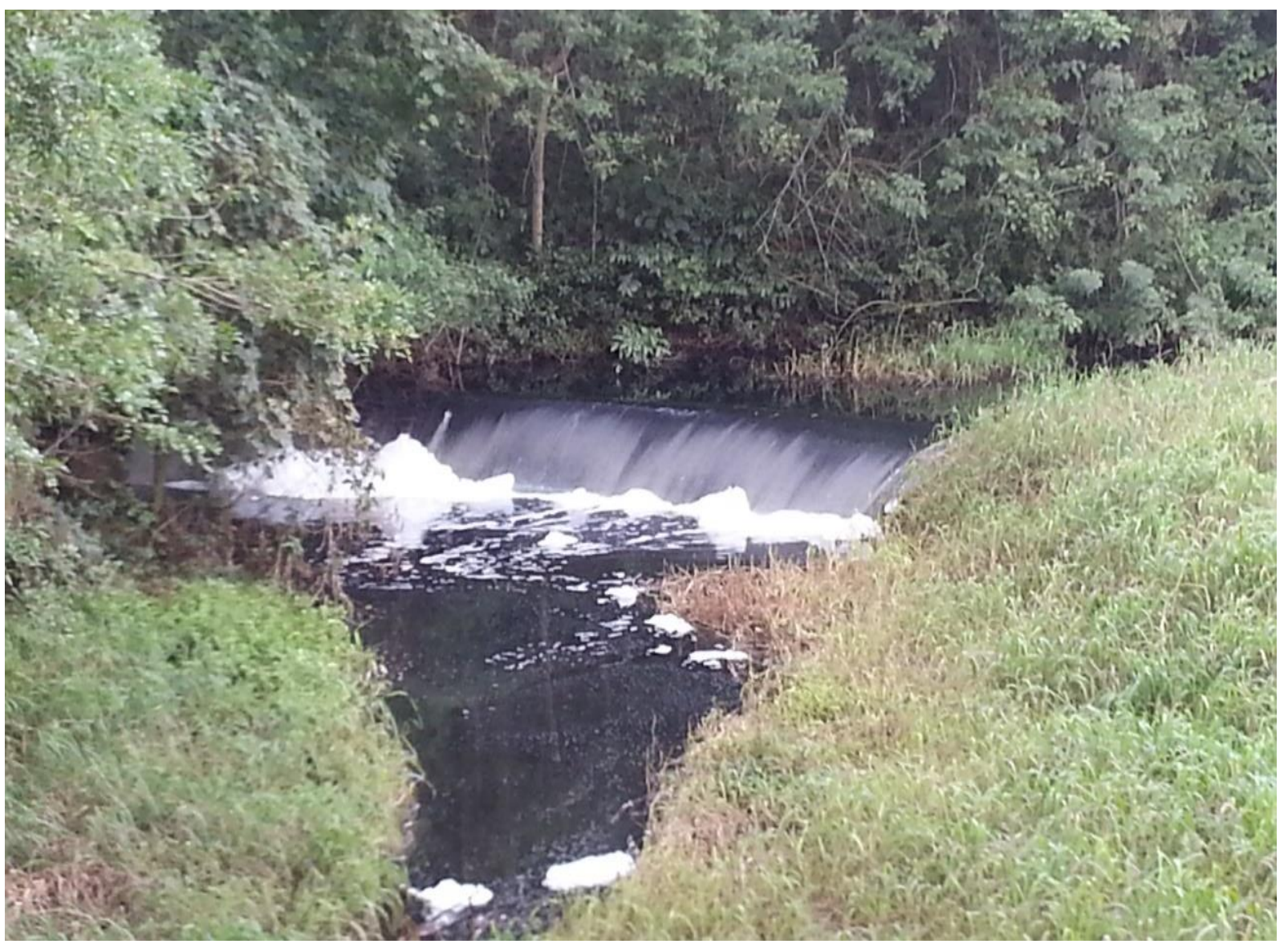

Figura 6 - Aspectos das águas no vertedor da barragem Mãe d'água.

\subsection{Caracterização da Área}

O local escolhido para o estudo de caso, situa-se no estado do Rio Grande do Sul, região metropolitana de Porto Alegre, mais precisamente no município de Viamão (Figura 7). A barragem Mãe d’Água é um afluente do Arroio Dilúvio, importante curso d'água que se estende para o município de Porto Alegre, cortando-o no sentido Leste-Oeste.

A barragem Mãe d’Água é o exutório de quatro arroios, correspondendo a uma área de 353 ha e se situa no Campus do Vale da Universidade Federal do Rio Grande do Sul. A Figura 8 representa a dimensão da bacia hidrográfica do barramento, caracterizando a localização e a área de estudo. 


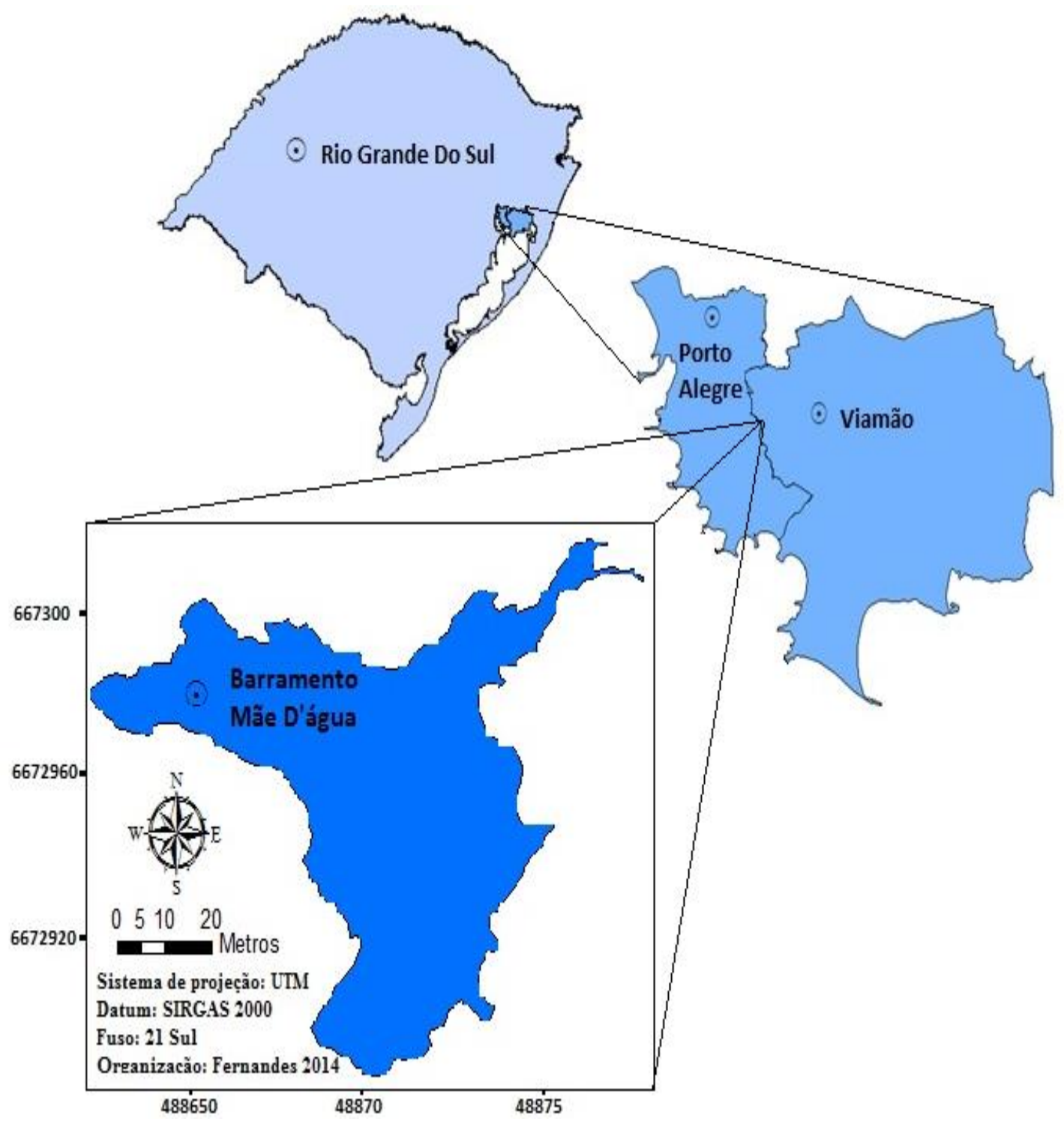

Figura 7- Localização e representação do represamento em estudo na Região Metropolitana de Porto Alegre- RS. 


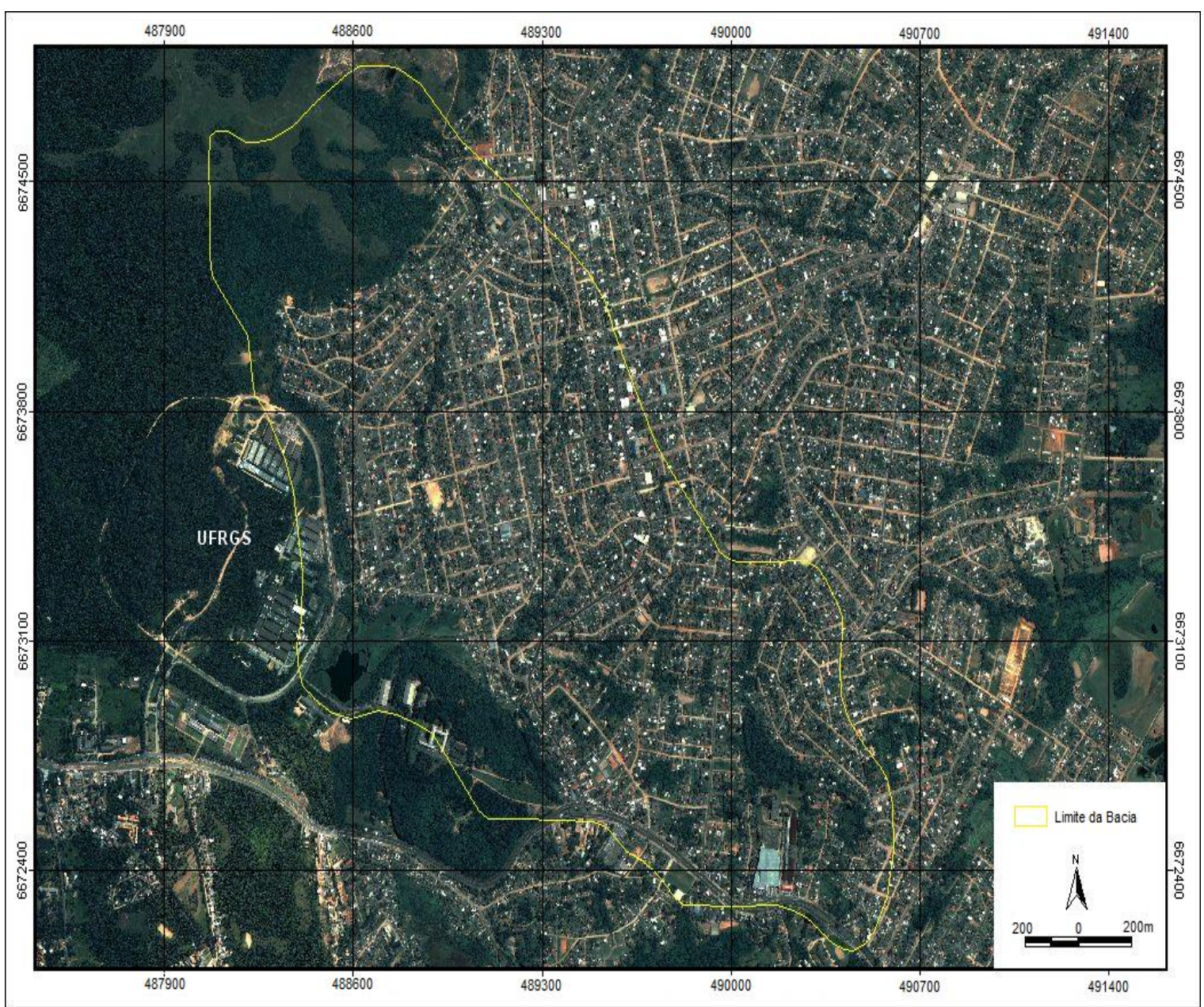

Figura 8- Carta imagem da área de estudo, base na imagem Quickbird do ano de 2003.

Fonte: Cardoso (2011)

A área encontra-se na porção sudeste do morro Santana, um corpo granítico, de forma alongada, com sentido NE-SW e cujo posicionamento está associado à implantação de uma zona de cisalhamento transcorrente ocorrida do final do Proterozóico. A topografia predominante é suavemente ondulada, o perfil do solo está diretamente relacionado com a rocha subjacente em virtude das suas propriedades texturais e a declividade das vertentes (ALVES, 2000). Segundo o levantamento de Reconhecimento de Solos do Rio Grande do Sul realizado em 1973, a área possui um solo do tipo Argissolo Vermelho - Amarelo Distrófico (STRECK et al, 2002).

Ainda nesse contexto, há o predomínio de um clima subtropical, justificado, segundo Livi (1999), por estar inserida na latitude $30^{\circ} \mathrm{S}$ e a $100 \mathrm{~km}$ do Oceano Atlântico é classificada como clima subtropical úmido (Cfa). Segundo a classificação de Koppen e Geiger (1928), por 
registrar valores de temperatura média do mês mais quente superior a $22{ }^{\circ} \mathrm{C}$. Como característica marcante tem-se a grande variabilidade dos elementos do tempo meteorológico ao longo do ano, com temperatura média para o mês mais frio (Junho/Julho) entre $-3{ }^{\circ} \mathrm{C}$ e 18 ${ }^{\circ} \mathrm{C}$ e superior a $22{ }^{\circ} \mathrm{C}$ no mês mais quente (Janeiro/ Fevereiro). A precipitação é uniforme todo o ano, com totais superiores a $1200 \mathrm{~mm}$ (ZURITA e TOLFO, 2000). 


\section{MATERIAL E MÉTODOS}

\subsection{Amostragem dos Perfis Sedimentares}

A coleta das amostras foi realizada no dia 09/06/2014. Os pontos da coleta dos testemunhos foram planejados, buscando obter uma melhor distribuição espacial no lago e respeitando a hidrodinâmica do local.

Foram amostrados um total de oito pontos no lago, mas, para a realização dos ensaios no presente estudo foram selecionados quatro testemunhos que melhor representassem a hidrodinâmica do local e a melhor localização e distribuição no lago, visando também a viabilidade econômica para execução do projeto, (Figura 9).

Os testemunhos foram amostrados e seus dados foram tabulados, como, as coordenadas geográficas dos pontos, altura da lâmina d'água e o comprimento do perfil sedimentar de acordo com a Tabela 2.

Tabela 2 - Informações dos testemunhos coletados

\begin{tabular}{ccccc}
\hline $\begin{array}{c}\text { Amostra } \\
\text { (Testemunho) }\end{array}$ & \multicolumn{2}{c}{$\begin{array}{c}\text { Coordenadas UTM (m) } \\
\text { (Elipsóide WGS-84) }\end{array}$} & $\begin{array}{c}\text { Lâmina } \\
\text { d'água } \\
(\mathbf{m})\end{array}$ & $\begin{array}{c}\text { Comprimento } \\
\text { do testemunho (m) }\end{array}$ \\
\hline T- 1 & 488716,3334 & 6672912,682 & 0,40 & 0,58 \\
\hline T- 4 & 488729,6452 & 6672984,722 & 0,40 & 0,58 \\
\hline T- 6 & 488681,4642 & 6672977,900 & 0,40 & 1,46 \\
\hline T- 8 & 488633,5455 & 6672976,312 & 0,40 & 1,06 \\
\hline
\end{tabular}




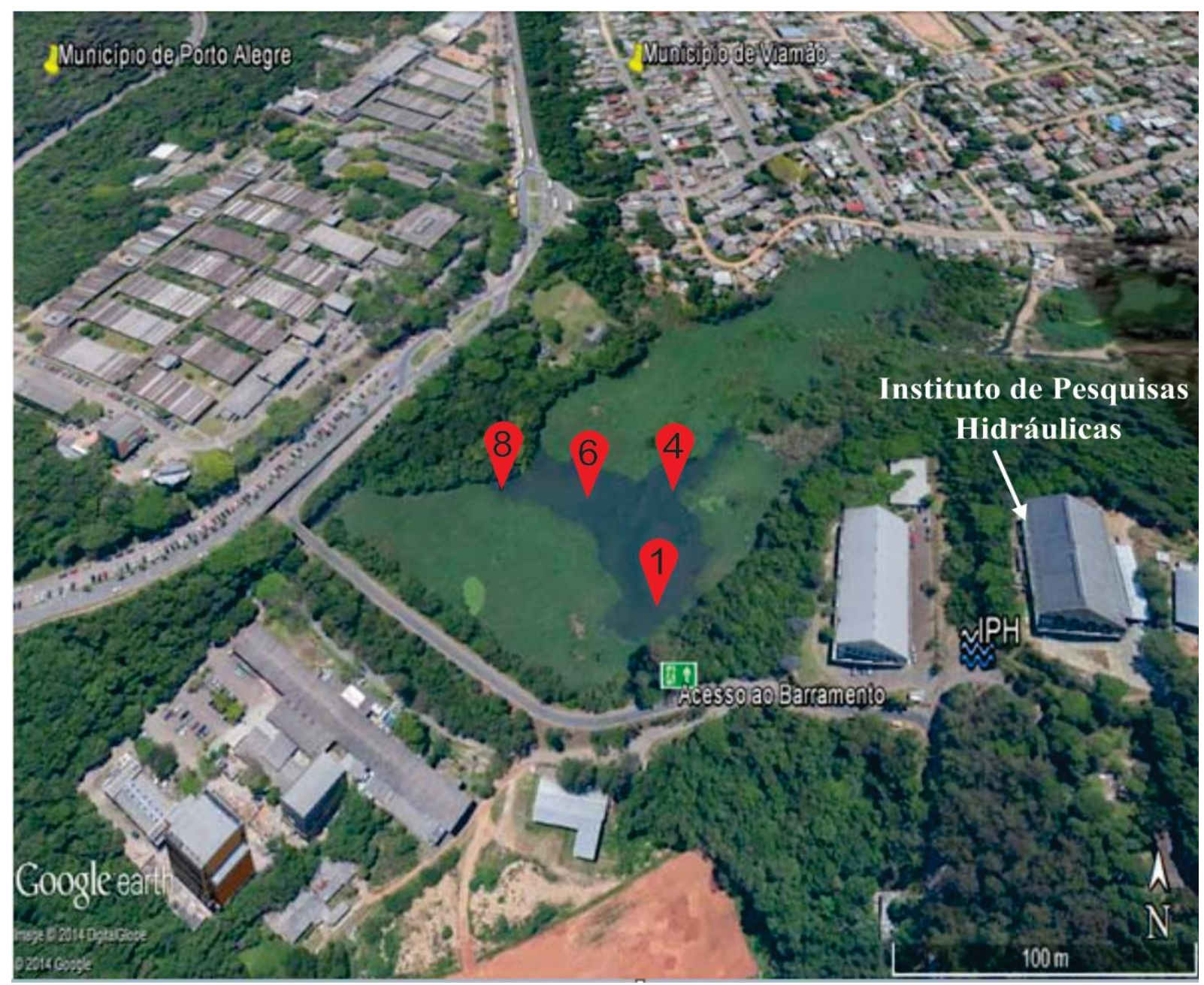

Figura 9 - Distribuição espacial dos pontos amostrados no lago.

\section{Fonte: Google Earth (2014)}

A técnica empregada foi do amostrador de núcleo (“Core Sampling”), sendo um conjunto de peças destacáveis, consistindo na introdução de um tubo cilíndrico de 75 milímetros de diâmetro rígido de PVC no sedimento de fundo, (Este estabelecido devido ao volume de amostras), assim, conforme o tubo é cravado no leito do corpo d'água, começa uma série de impactos no tubo, produzindo a perfuração e coleta do sedimento através de uma força manual, repetidas vezes, até que encontre uma barreira suficientemente sólida e que impeça a continuidade da penetração, objetivando a conformidade da amostra. A extremidade do tubo possui uma borda cortante, servindo para adentrar no sedimento e um retentor, tem como função permitir a entrada da amostra e impedir sua saída. Na Figura 10 é apresentada a extração do testemunho. 
No ato da coleta, foi utilizada uma embarcação, que forneceu segurança ao desenvolvimento da atividade, garantindo a estabilidade necessária da tripulação e retirada dos testemunhos. A Figura 11 permite a observação dos oito testemunhos coletados e prontos para seguir ao laboratório.

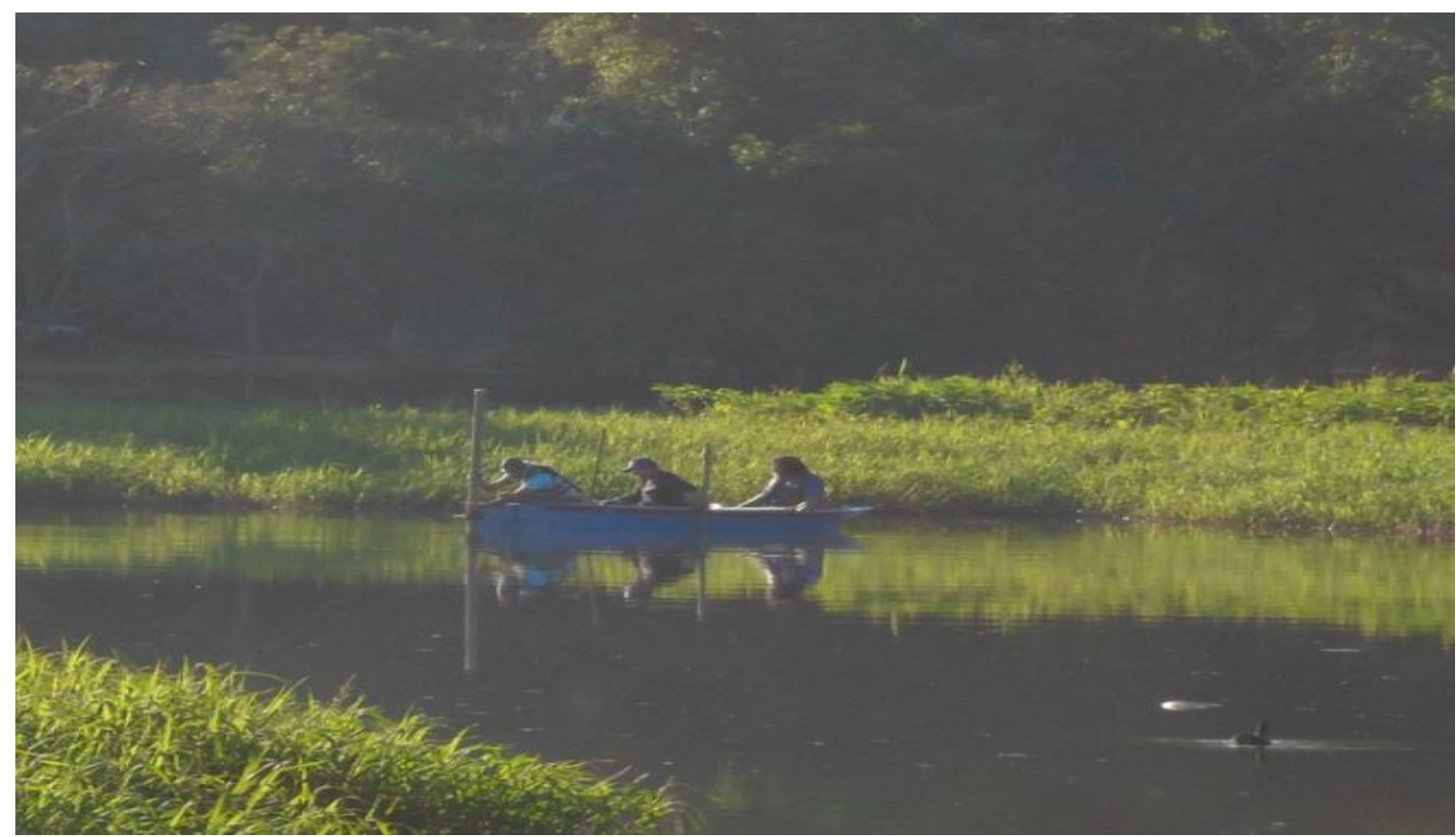

Figura 10 - Extração do testemunho 4 no lago da barragem Mãe d'água.

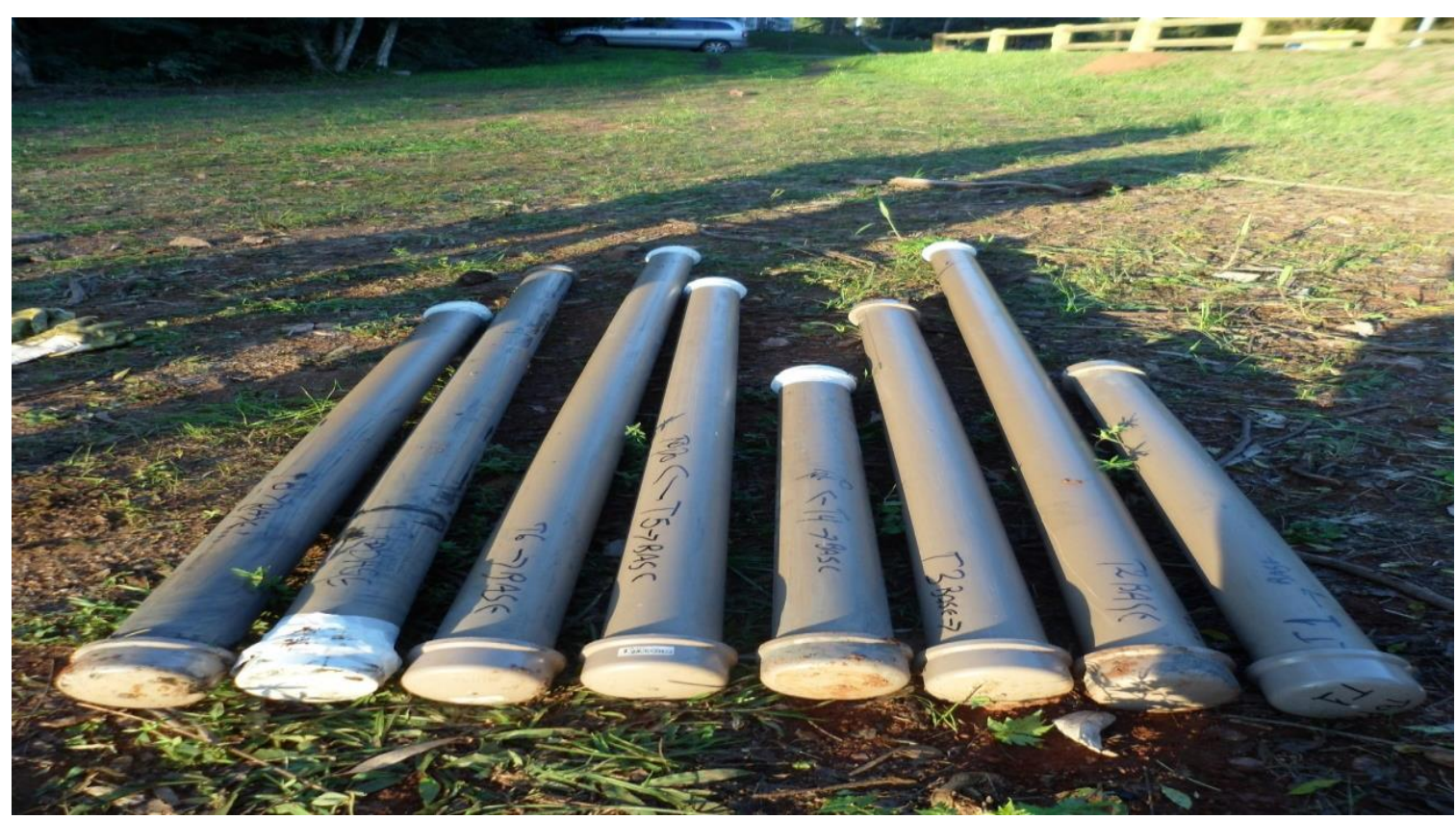

Figura 11 - Testemunhos coletados e prontos para seguir ao laboratório. 


\subsection{Processamento das amostras}

O processamento das amostras teve início logo após a coleta, onde os testemunhos coletados foram transportados até o laboratório de análises de solo da UFRGS, sendo abertos na mesa esterilizada e com o ferramental desenvolvido para a excelência da abertura do tubo que preservara a amostra até o momento, conforme Figuras 12 e 13.

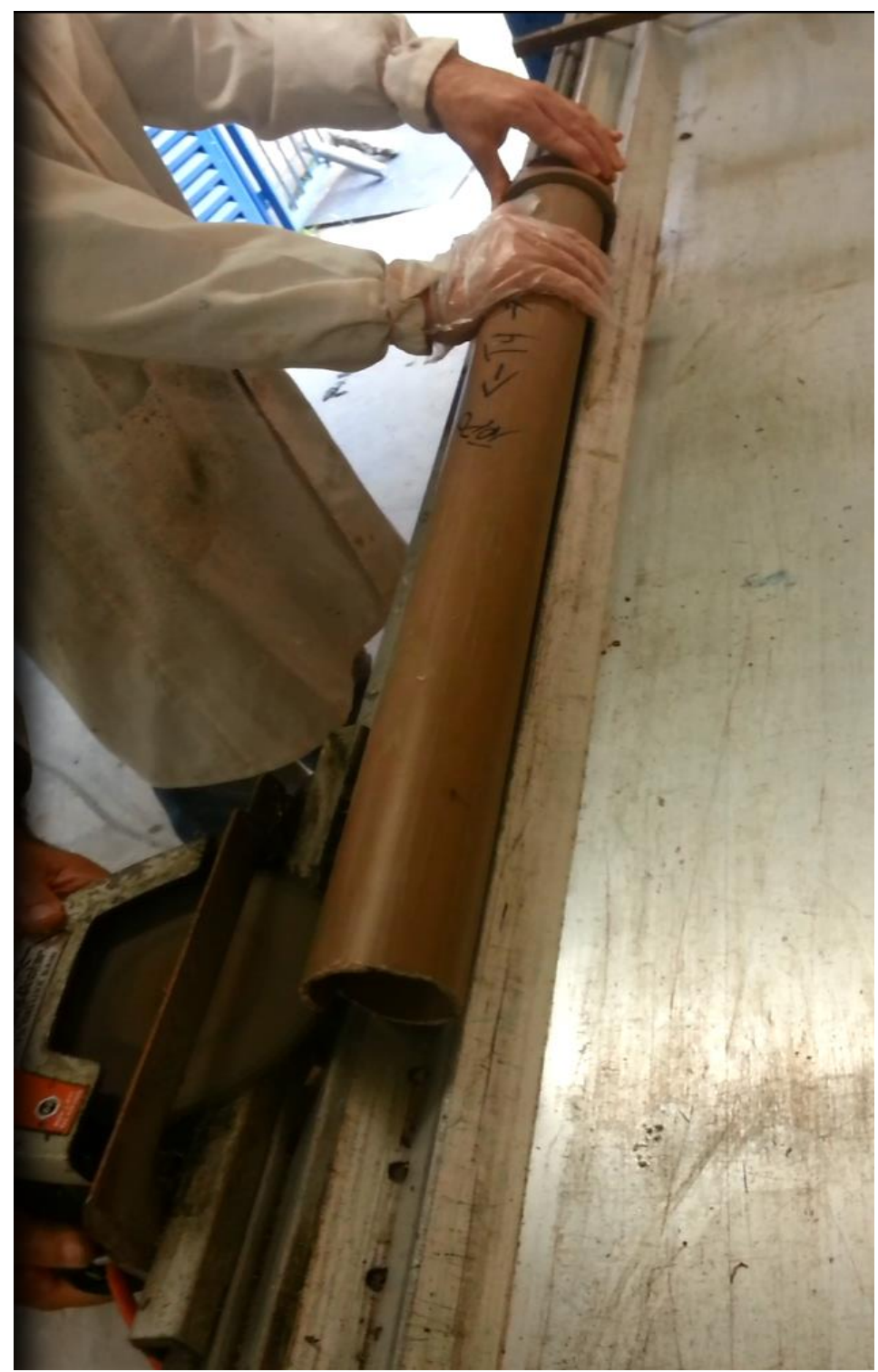

Figura 12 - Abertura do tubo de $75 \mathrm{~mm}$ de diâmetro que preserva as amostras coletadas, (Testemunho 4). 


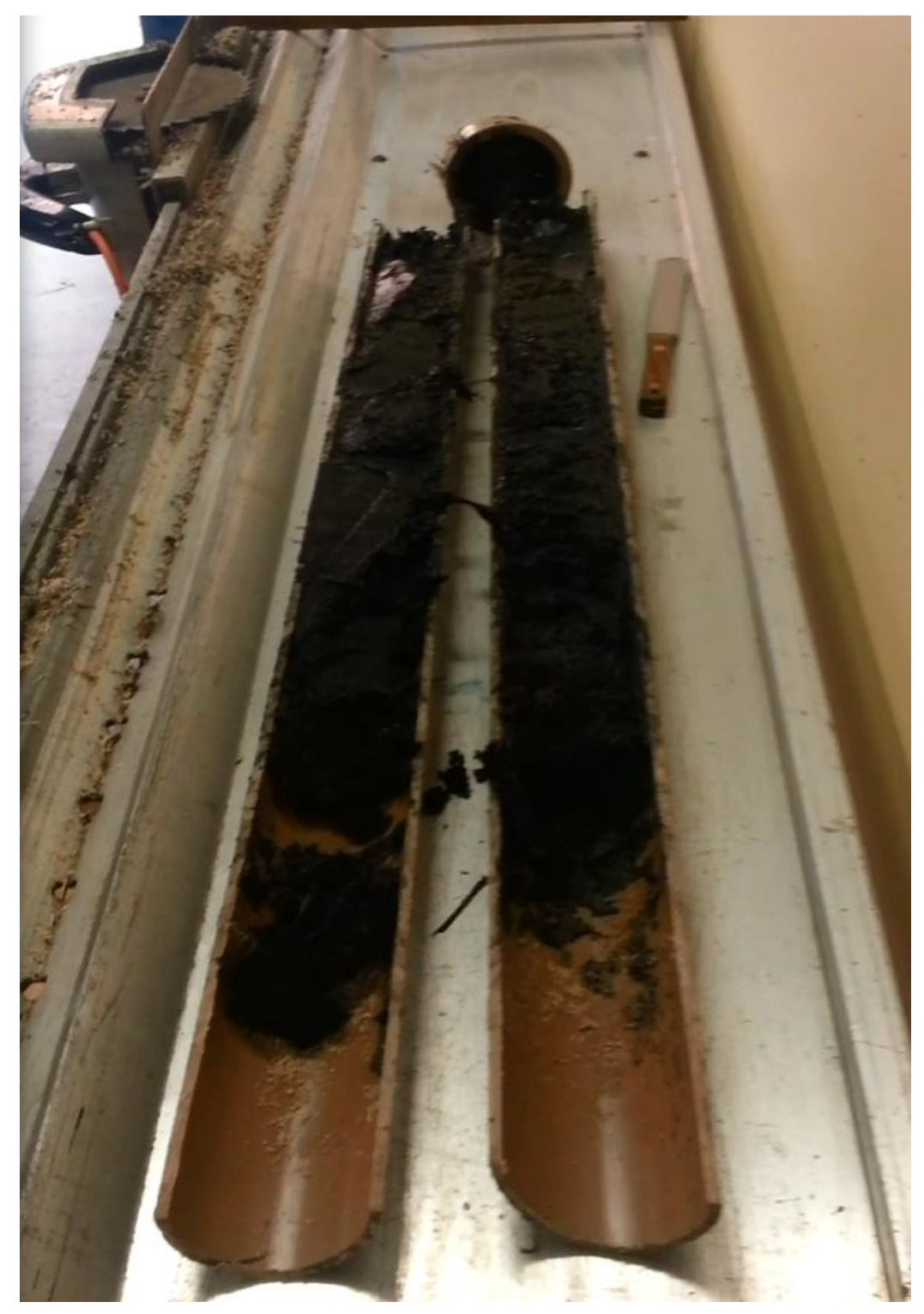

Figura 13 - Testemunho 4, aberto após a coleta na mesa de abertura esterilizada.

As amostras foram fatiadas a cada 2 centímetros, (Padrão estabelecido pelo laboratório, objetivando intervalos próximos entre as camadas sedimentares) gerando uma grande quantidade de sub-amostras, como apresentada na Figura 14. Para a análise dos metais, teores de matéria orgânica e granulometria, foram selecionadas as sub-amostras fatiadas com espessura de $2 \mathrm{~cm}$ sendo presente um intervalo de $6 \mathrm{~cm}$ entre uma sub-amostra e outra. Após a sub-amostragem, foram devidamente embaladas em postes esterilizados de material PVC e congelados conforme as Figuras 14 e 15 a seguir. 


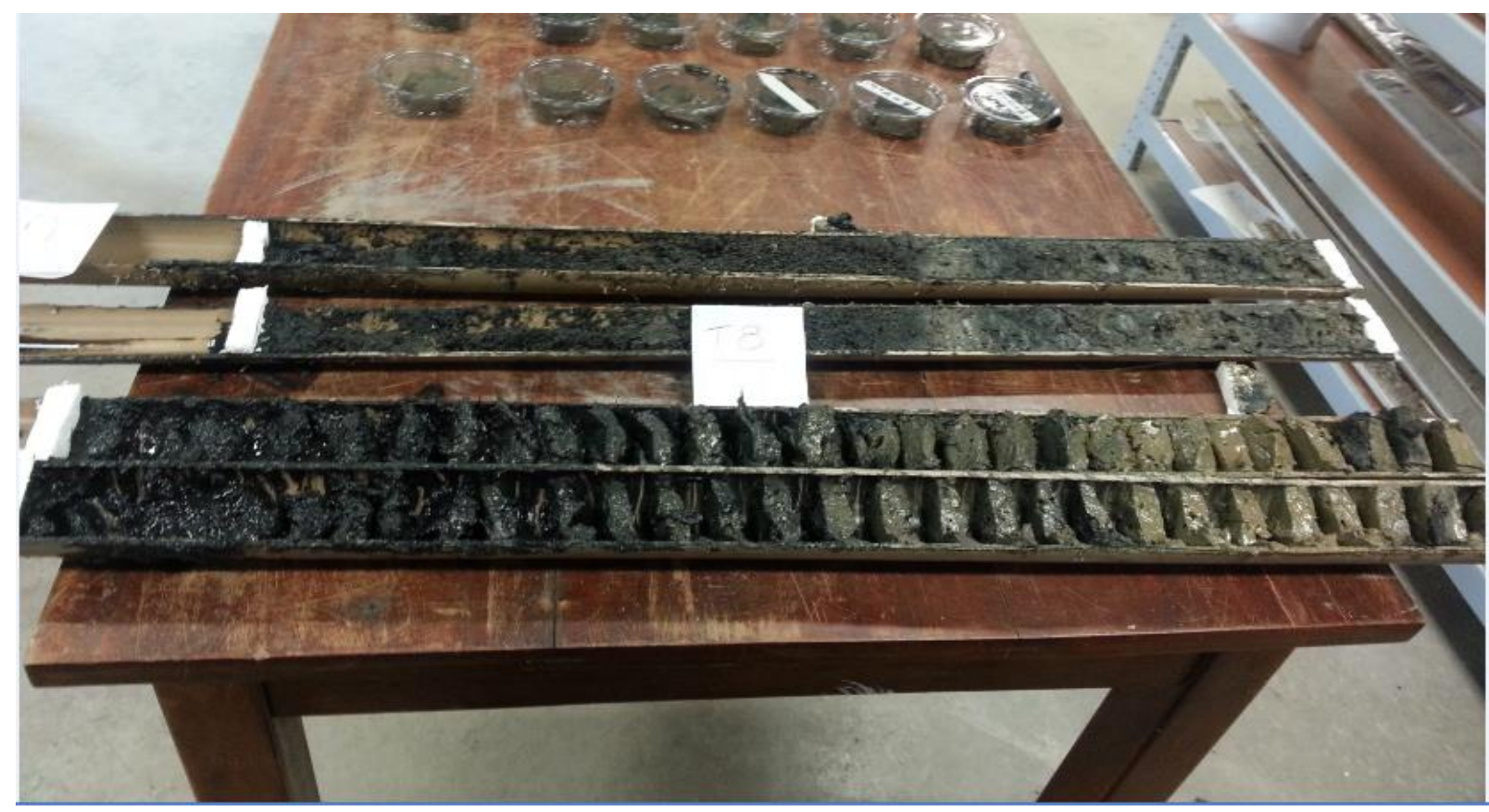

Figura 14- Testemunhos fatiados a cada 2 centímetros.

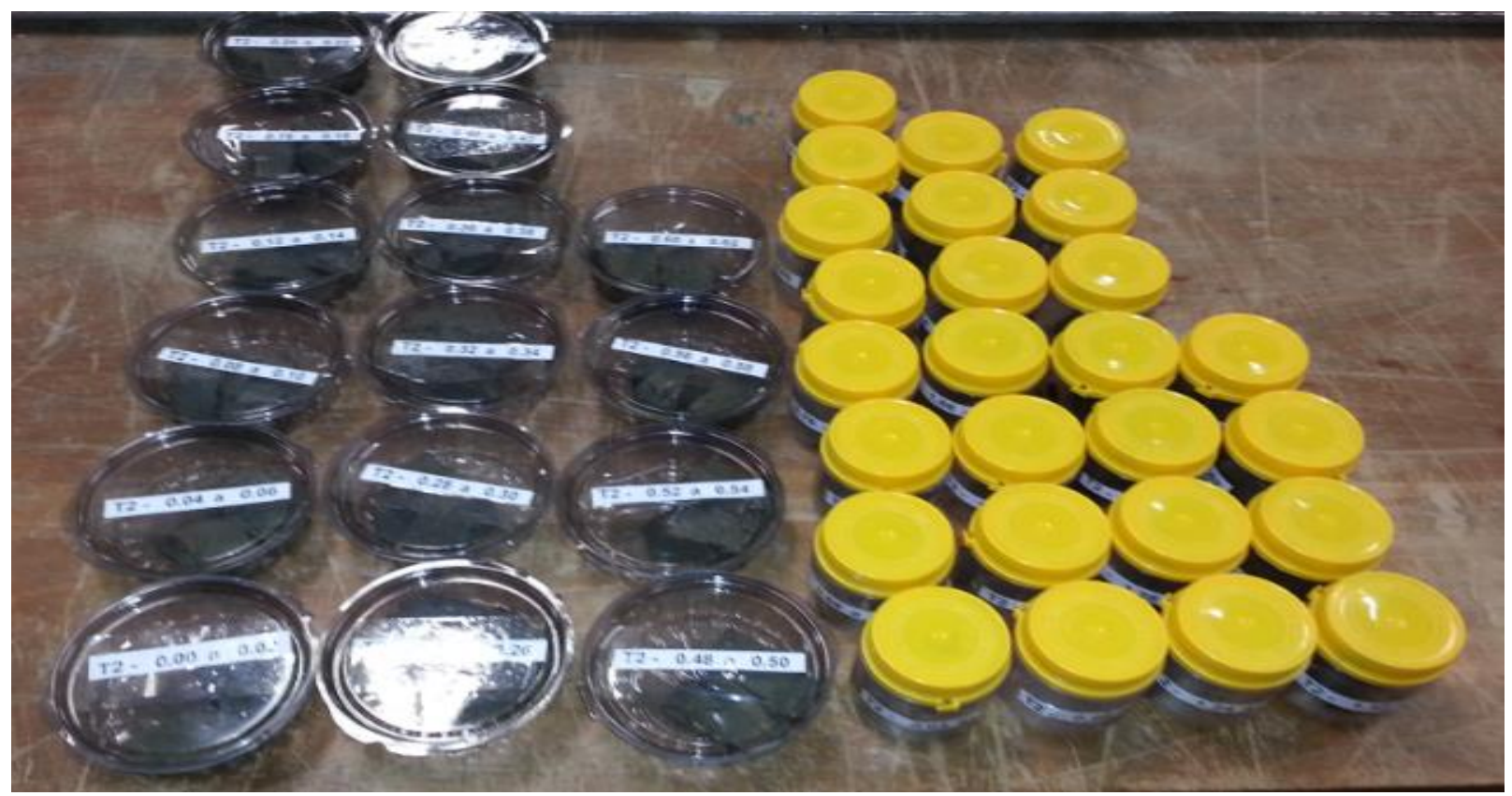

Figura 15-Armazenamento das sub-amostras em recipientes estéreis de PVC.

Nas sub-amostras que são destinadas a investigação do enriquecimento por metais, é imprescindível e deve-se evitar o contato com qualquer material metálico. Assim, as amostras foram embaladas em recipientes estéreis de material de PVC e acondicionadas para posteriores análises físicas e químicas. 


\subsection{Teores de Matéria Orgânica Total ou (COT)}

O teor de matéria orgânica total presente nas amostras de sedimentos foi realizado no Laboratório de Zootecnia do departamento de solos da UFRGS. Foi utilizado no processo de determinação da matéria orgânica total (M.O.) contido nas amostras, o analisador elementar Thermo Scientific Flash 2000- NC Soil Analyzer, que necessita de apenas alguns miligramas de amostra para análise. Este equipamento, baseia-se no processo bem conhecido de flash dinâmico de combustão, o que produz uma combustão completa da amostra a $1800{ }^{\circ} \mathrm{C}$, seguida por uma determinação exata e precisa dos gases elementares produzidos. O equipamento Thermo Scientific Flash NC, proporciona um ciclo de análise rápida para a determinação dos resultados, analisando 31 amostras por ciclo, (Figura 16).

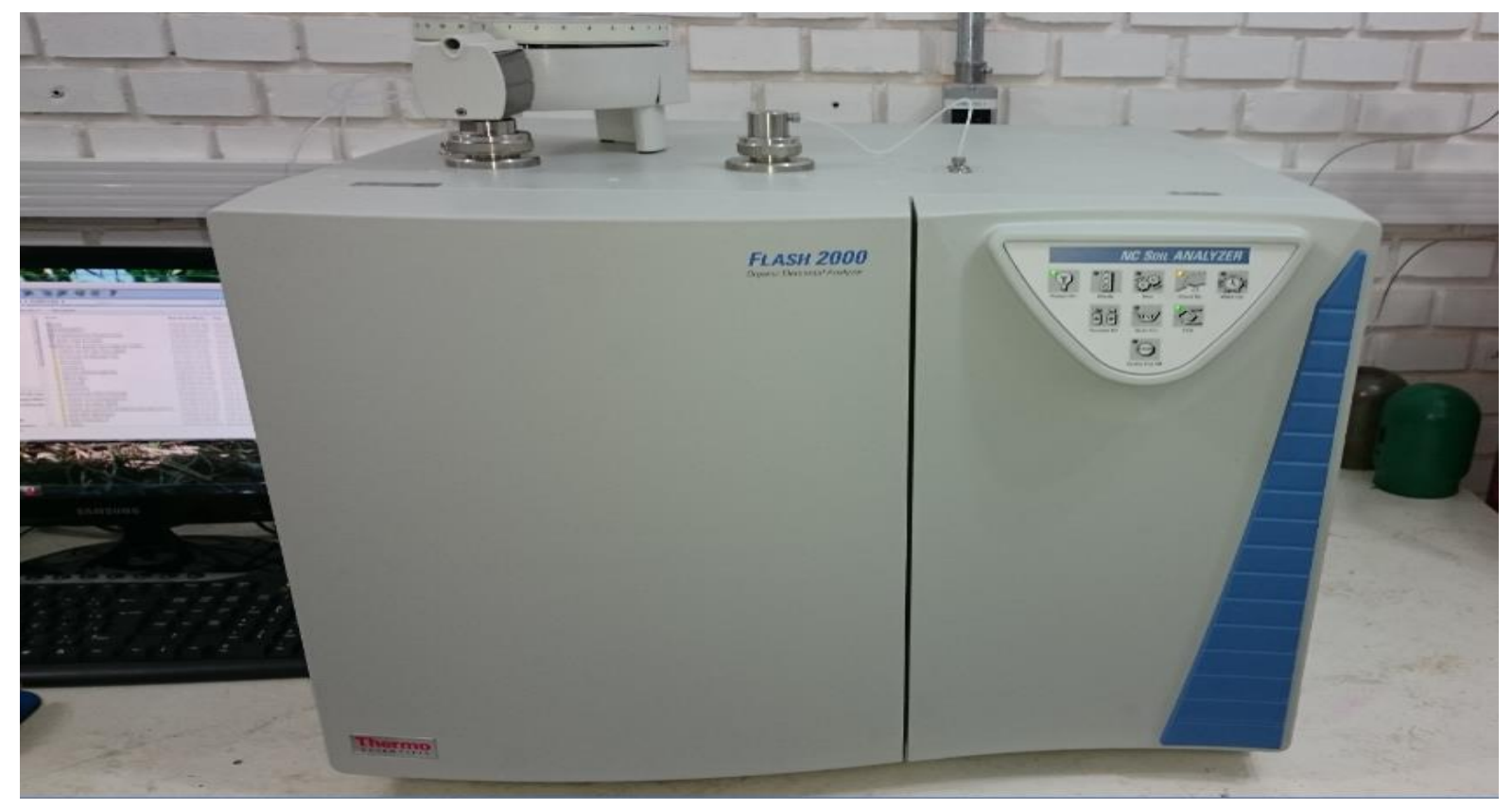

Figura 16- Fotografia do equipamento Thermo Scientific Flash 2000- NC Soil Analyzer.

O pré-tratamento das amostras ocorreu após serem secas em estufa a $60{ }^{\circ} \mathrm{C}$. Em seguida, procedeu-se à maceração dos grãos (almofariz e pistilo com ponta de borracha) para 0 posterior quarteamento. As amostras foram pesadas em uma balança de precisão com capela, utilizando cerca de $2 \mathrm{mg}$ (Conforme o manual do equipamento), e tabuladas, (Figura 17), finalmente foram levadas ao equipamento Thermo Scientific Flash 2000. 


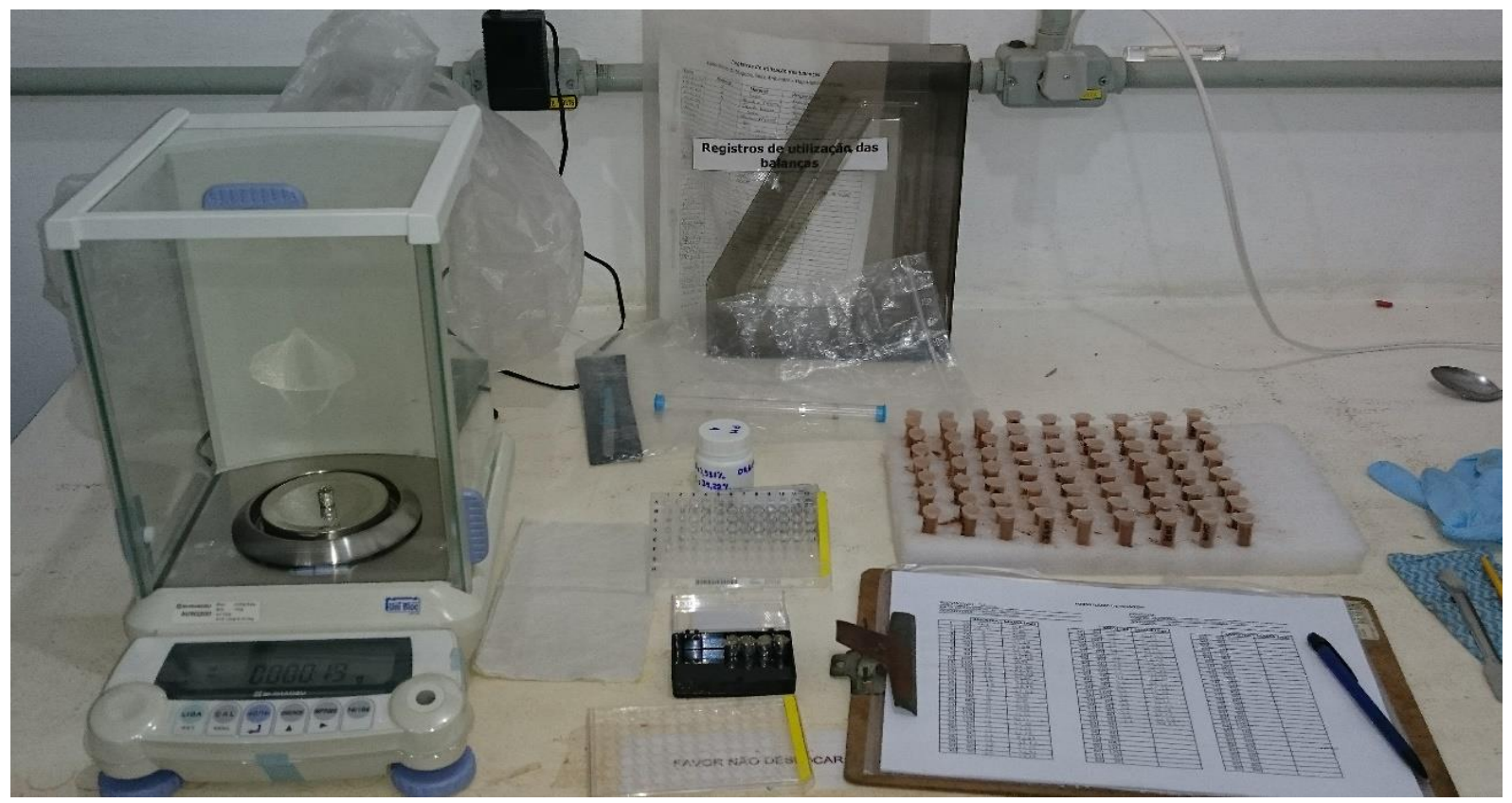

Figura 17- Processamento das amostras para inserção no equipamento Flash 2000- NC Soil Analyzer.

\subsection{Granulometria}

As amostras foram enviadas para o laboratório do Centro de Estudos de Geologia Costeira e Oceânica (CECO) situado no campus da Universidade Federal do Rio Grande do Sul (UFRGS) onde ocorreu a determinação das frações granulométricas.

Para o pré tratamento das amostras precedeu-se com a secagem em estufa a $60^{\circ} \mathrm{C}$. Em seguida, à maceração dos grãos (almofariz e pistilo com ponta de borracha) e realizou-se quarteamento. A análise granulométrica foi realizada seguindo-se a NBR 7181 ABNT (1984). A determinação da fração granulométrica dos sedimentos finos (partículas com diâmetros inferiores a 0,075 mm), foi realizada através do método da Pipeta, sedimentação, através da velocidade de queda das partículas das amostras em um meio líquido, sendo que para isso tomou-se como base a lei de Stokes, que correlaciona a velocidade de queda das partículas esféricas com o seu diâmetro.

Através frações granulométricas obtidas foram classificados individualmente de acordo com a profundidade de cada sub-amostra, sendo expressos em escalas de tamanho, os materiais retidos de grossos e finos juntamente com a frequência simples, sendo a forma 
representada segundo o modelo proposto pela NBR 7181 ABNT (1984), por classes texturais de areias, silte e argila, assim, confeccionar o triângulo textural da ABNT, fornecendo uma análise mais detalhada dos dados.

\subsubsection{Granulometria para metais}

As sub-amostras de sedimento foram homogeneizadas em almofariz de ágata e, então, peneiradas em peneira de PVC e náilon com malha de $63 \mu \mathrm{m}$, a fração mais grosseira destas amostras foi dispensada, visto que a determinação dos elementos-traço foi realizada na fração silte/argila $(<63 \mu \mathrm{m})$ como recomentado pela Organização Mundial da Saúde (WHO 1982; HOROWITZ, 1991; POLETO e TEIXEIRA, 2006).

\subsection{Determinação dos metais pesados em sedimentos}

Foram encaminhados ao Laboratório de Solos da Faculdade de Agronomia da UFRGS cerca de $5 \mathrm{~g}$ de cada sub-amostra para avaliação da concentração total dos metais zinco e níquel. As digestões foram realizadas em duplicata mais "1 branco" (amostra branca é feita utilizando os mesmos reagentes e procedimentos, mas sem a adição da amostra de sedimentos) para o controle de qualidade das análises (Poleto \& Gonçalves, 2006). Além disso, foram utilizados dois materiais de referência, cujas concentrações são conhecidas, adquiridos junto a USGS (U.S. Geological Survey): SGR-1b e SCO-1.

A metodologia de digestão ácida empregada foi a EPA 3050, que é direcionada a análise de concentração de elementos inorgânicos em sedimentos, lodos e solos, e foi desenvolvida e adotada pela U.S. Environment Protection Agency. Esta metodologia envolve fortes digestões ácidas das amostras, dissolvendo quase todos os elementos que podem se tornar biodisponíveis. Por isto, elementos ligados em estruturas de silicatos normalmente não são dissolvidos por esse procedimento, já que normalmente estes não são móveis no ambiente (EPA, 1996). 
Para a implementação do método é necessário de 1 a $2 \mathrm{~g}$ de sedimento que é digerido por repetidas adições de ácido nítrico $\left(\mathrm{HNO}_{3}\right)$ e peróxido de hidrogênio $\left(\mathrm{H}_{2} \mathrm{O}_{2}\right) 30 \%$. Posteriormente é adicionado ácido clorídrico $(\mathrm{HCl})$ visando a liberação dos metais mais resistentes (EPA, 1996).

$\mathrm{Na}$ etapa final do método foi realizada a leitura dos extratos das amostras resultantes das extrações no equipamento de espectroscopia de emissão indutiva de plasma acoplado (ICPOES), marca Perkin Elmer, no Laboratório de Solos da UFRGS.

\subsection{Valores de "Background"}

Os valores de background, utilizados nessa pesquisa, foram baseados no trabalho de Poleto (2007). O autor obteve uma concentração média representativa das concentrações naturais dos metais analisados na área de estudo através de três amostras compostas (cada amostra era resultante de outras três sub-amostras da camada superior do solo). As coletas foram realizadas na região de cabeceira da bacia do Lago Mãe d'Água, no alto do Morro Santana, em áreas de mata que não apresentavam alterações antrópicas. Os valores obtidos para os metais Zinco e Níquel são apresentados na Tabela 3.

Tabela 3 - Valores de base dos metais-traço analisados

\begin{tabular}{cc}
\hline Metal-traço & Valores de background $\left(\mathbf{m g}^{-k^{-1}}\right)$ \\
\hline Zinco & 47,4 \\
Níquel & 4,9 \\
\hline
\end{tabular}




\section{RESULTADOS E DISCUSSÃO}

\subsection{Granulometria}

Um dos principais fatores que controlam os processos de adsorção de metais em sedimentos é o seu tamanho de partícula (SIMPSON et al., 2005). A área superficial específica (ASE) das diferentes frações de sedimentos varia em ordens de grandeza, alterando assim os números de sítios de adsorção dos contaminantes. A Tabela 4 apresenta as porcentagens das frações granulométricas areia, silte e argila dos diferentes testemunhos de sedimentos. É possível verificar uma grande variação entre o tamanho das partículas em todos os testemunhos, com exceção de T4 que se faz mais homogêneo e caracterizando por predominância de francosiltoso. Os demais testemunhos (1, 6 e 8) apresentam uma caracterização das partículas desde franco-siltosa partindo do fundo do testemunho, está próximo a rocha, até muito argilosa na superfície do sedimento. 
Tabela 4- Classificação granulométrica (\%) em diferentes profundidades $(\mathrm{cm})$ dos testemunhos amostrados.

\begin{tabular}{|c|c|c|c|c|c|c|c|c|c|c|c|c|}
\hline \multicolumn{13}{|c|}{ Classificação Granulométrica (\%) } \\
\hline \multirow{2}{*}{$\begin{array}{l}\text { PROFUNDIDADE } \\
\text { (Centímetros) }\end{array}$} & \multicolumn{3}{|c|}{ T1 } & \multicolumn{3}{|c|}{ T4 } & \multicolumn{3}{|c|}{ T6 } & \multicolumn{3}{|c|}{ T8 } \\
\hline & AREIA & SILTE & ARGILA & AREIA & SILTE & ARGILA & AREIA & SILTE & ARGILA & AREIA & SILTE & ARGILA \\
\hline 2 & 0,18 & 44,84 & 54,98 & 5,18 & 74,07 & 20,75 & 43,86 & 41,65 & 14,49 & 4,08 & 40,56 & 55,37 \\
\hline 18 & 0,32 & 51,22 & 48,45 & 8,84 & 69,87 & 21,29 & 32,61 & 42,88 & 24,51 & 0,34 & 44,55 & 55,12 \\
\hline 26 & 0,50 & 58,02 & 41,48 & 9,69 & 73,39 & 16,92 & 0,04 & 31,36 & 68,60 & 0,57 & 33,77 & 65,66 \\
\hline 34 & 0,50 & 67,42 & 32,08 & 8,23 & 72,34 & 19,43 & 0,07 & 18,17 & 81,77 & 0,87 & 39,34 & 59,80 \\
\hline 50 & 0,64 & 70,11 & 29,24 & 31,76 & 55,01 & 13,22 & 0,01 & 30,07 & 69,92 & 0,65 & 63,09 & 36,26 \\
\hline 58 & 1,12 & 79,63 & 19,25 & 33,14 & 56,44 & 10,42 & 0,01 & 38,86 & 61,13 & 0,38 & 55,08 & 44,54 \\
\hline 66 & & & & & & & 0,01 & 44,48 & 55,51 & 0,01 & 49,31 & 50,68 \\
\hline 74 & & & & & & & 0,77 & 56,13 & 43,10 & 0,08 & 57,10 & 42,83 \\
\hline 82 & & & & & & & 0,18 & 49,57 & 50,25 & 0,83 & 66,49 & 32,68 \\
\hline 90 & & & & & & & 0,00 & 43,21 & 56,79 & 6,72 & 62,19 & 31,09 \\
\hline 130 & & & & & & & 0,86 & 69,50 & 29,64 & & & \\
\hline 138 & & & & & & & 0,58 & 65,85 & 33,58 & & & \\
\hline 146 & & & & & & & 7,62 & 67,18 & 25,21 & & & \\
\hline
\end{tabular}


As Figuras 18 a 21 utilizam os dados do Quadro 1 para ilustrar as diferentes classes texturais de cada testemunho através do triângulo textural da ABNT (1995), fornecendo uma análise mais detalhada dos dados do barramento Mãe d'Água. Percebe-se uma grande dispersão do tamanho de partículas em todos os testemunhos, com exceção de T4. Os testemunhos 1, 6 e 8 apresentam uma variação de partículas desde franco-siltosa próximo à rocha até muito argilosa na superfície do sedimento. Já o testemunho 4 apresenta uma textura franco-siltosa em todo seu perfil. Como partículas finas são aquelas que geralmente possuem maior ASE e sítios de adsorção e consequentemente os maiores teores de metais, maiores concentrações de Ni e Zn são esperadas nesse ponto do barramento.

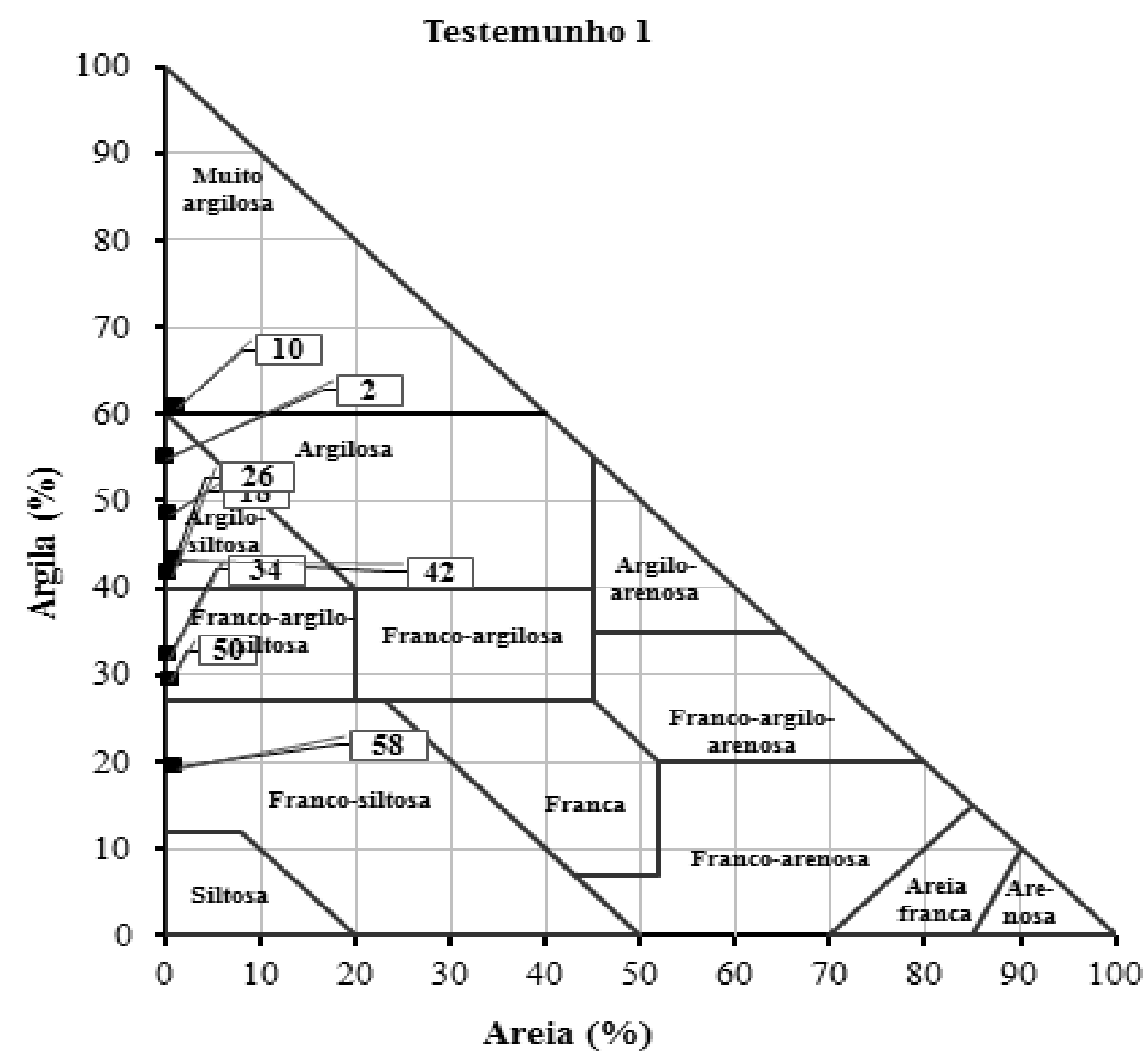

Figura 18 - Classificação de acordo com o triângulo textural referente ao testemunho de sedimento 1 do barramento Mãe d'Água.

Fonte adaptado de Gerakis e Baer (1999) 


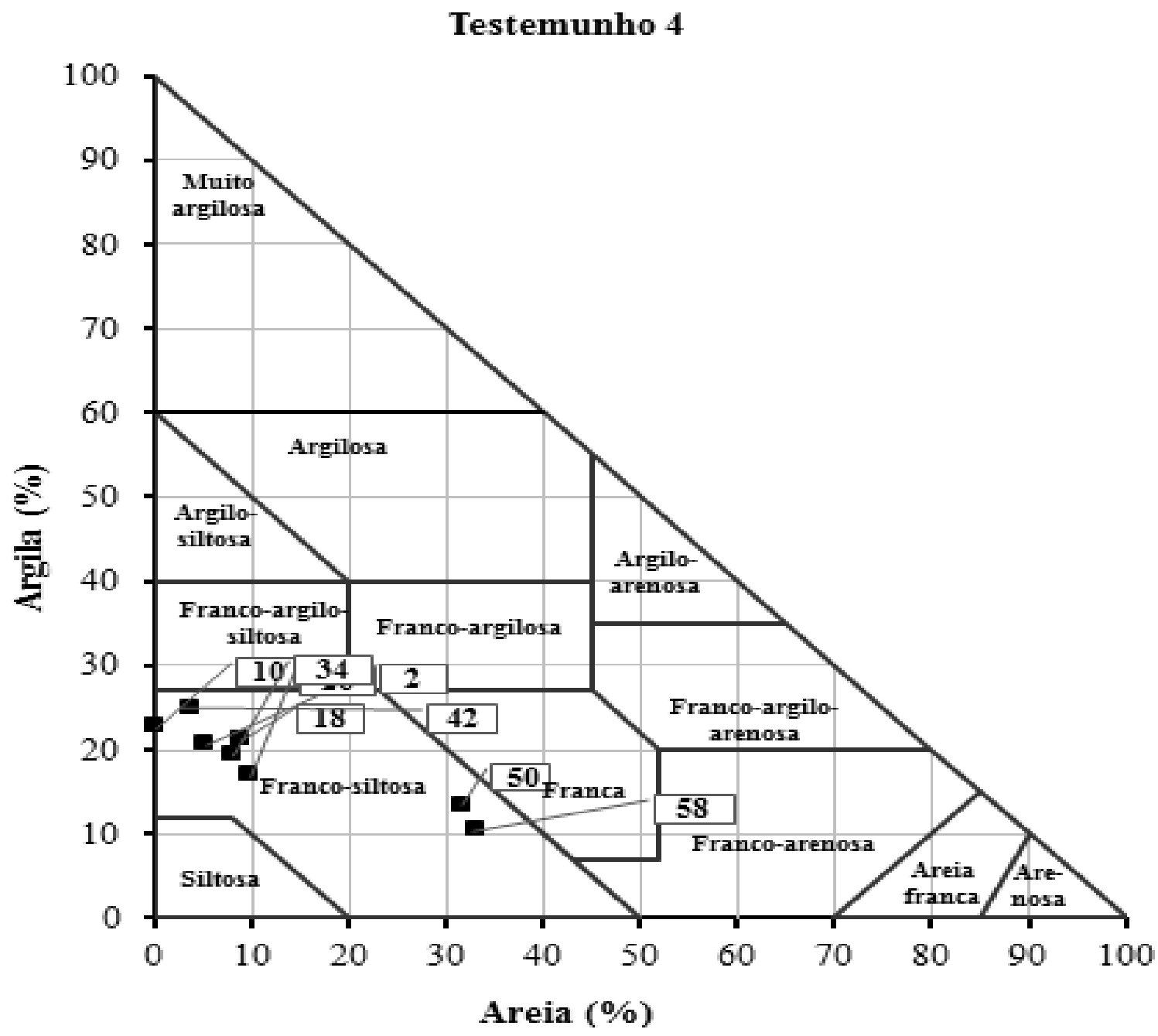

Figura 19 - Classificação de acordo com o triângulo textural referente ao testemunho de sedimentos 4 do barramento Mãe d'Água.

Fonte adaptado de Gerakis e Baer (1999) 


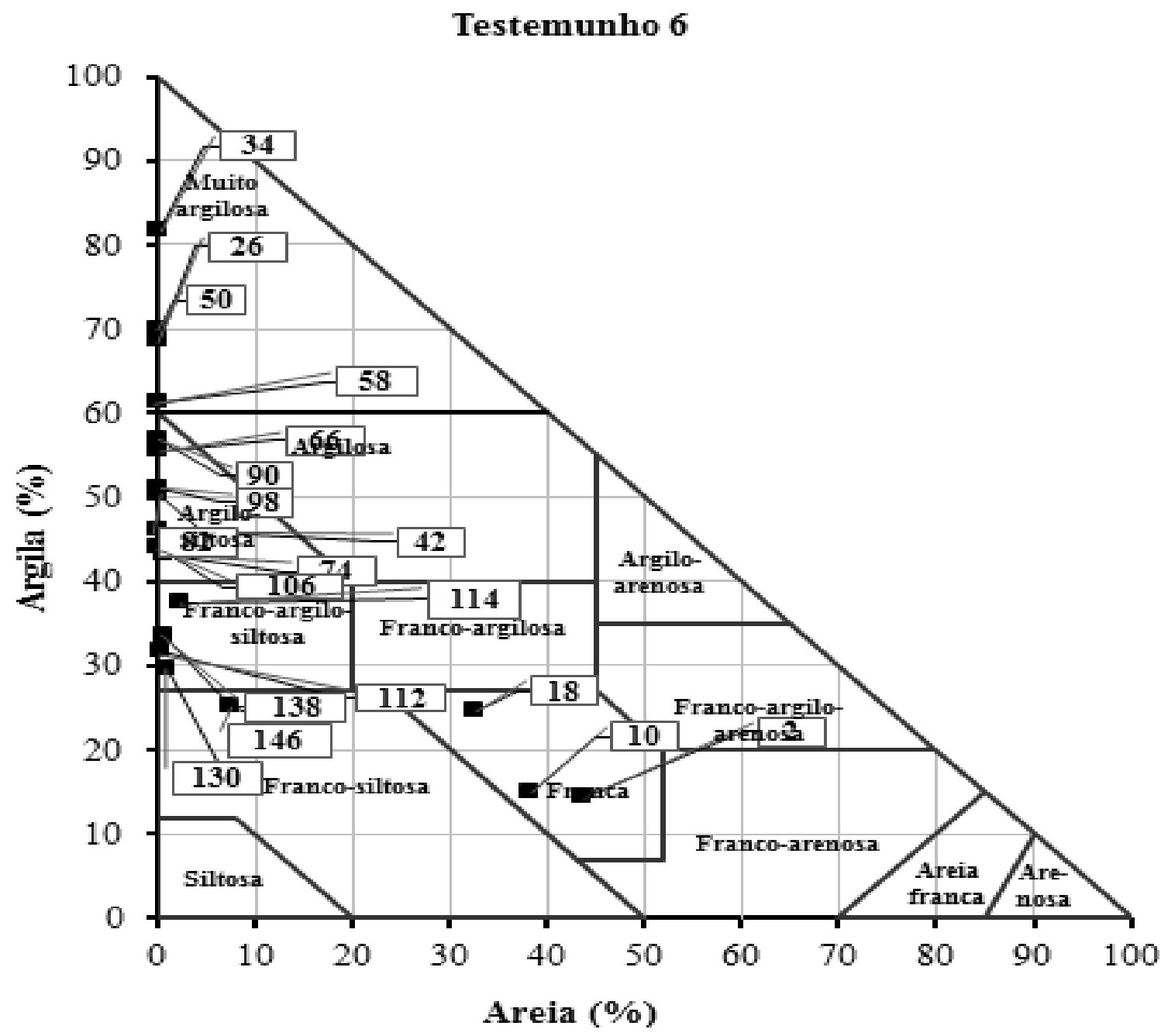

Figura 20 - Classificação de acordo com o triângulo textural referente ao testemunho de sedimentos 6 do barramento Mãe d'Água.

Fonte adaptado de Gerakis e Baer (1999) 


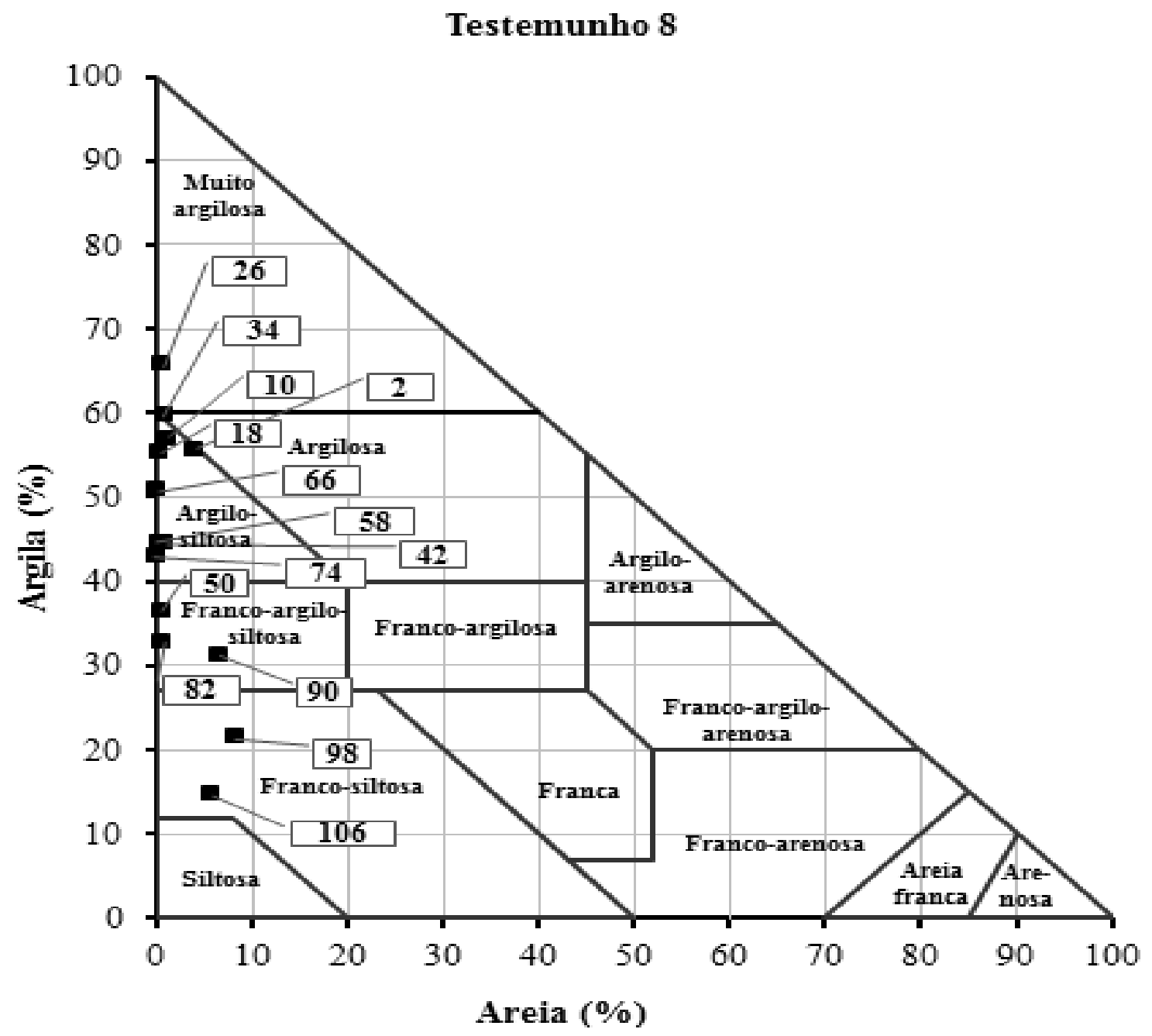

Figura 21 - Classificação de acordo com o triângulo textural referente ao testemunho de sedimentos 8 do barramento Mãe d'Água.

Fonte adaptado de Gerakis e Baer (1999)

\subsection{Controle de qualidade das amostras de metais ( $\mathrm{Zn}$ e Ni)}

A determinação dos níveis de metais em dois materiais de referência padrões (MRP) do laboratório de solos da USGS foi realizada com o intuito de se garantir o controle da qualidade das análises (Tabela 5). Os níveis de recuperação determinados neste estudo apresentaram boa reprodutibilidade, demonstrando que a metodologia apresentou bom desenvolvimento ao emprego da digestão dos metais ( $\mathrm{Zn}$ e Ni) em estudo. 
Tabela 5 - Concentrações de Zn e Ni da amostra de referência Green River Shale (SGR1b) e Cody Shale (SCo-1) da USGS ${ }^{a}$

\begin{tabular}{lll}
\hline \multicolumn{1}{c}{ Elemento } & Amostra certificada & \multicolumn{1}{c}{$\begin{array}{c}\text { Determinado } \\
\text { neste estudo por ICP-OES }\end{array}$} \\
\hline Green River Shale (SGR-1b) & Média \pm DP & Média \\
\hline Ni (mg kg-1) & $29 \pm 5$ & 27 \\
Zn (mg kg & & 77 \\
\hline Cody Shale (SCo-1) & $74 \pm 9$ & \\
\hline Ni (mg kg-1) & & 24 \\
Zn (mg kg & & 110 \\
\hline
\end{tabular}

${ }^{a}$ United States Geological Survey; DP = Devisor padrão.

É possível verificar que os valores apresentados na Tabela 5 apresentam boa média e seus valores estão dentro do desvio padrão de cada amostra certificada (SGR-1b e SCo-1), onde demonstra que a metodologia apresentou bom desenvolvimento ao emprego da digestão dos metais e apresenta resultados confiáveis.

\subsection{Concentrações totais de zinco e níquel nos testemunhos sedimentares}

\subsubsection{Concentrações total de zinco nos testemunhos de sedimentos}

Os teores totais de metais incluem todas as formas de determinado elemento no sedimento, seja ele na forma de íons ligados à estrutura cristalina de minerais primários e secundários; adsorvidos na superfície de minerais secundários como argilominerais, óxidos e carbonatos; complexados pelo estado sólido da matéria orgânica; ou na forma de íons livres na coluna d'água (ALLOWAY, 2010). 
Nas áreas urbanas, as partículas de poeira dispostas nas vias de tráfego entram em contato com os resíduos do desgaste e emissões dos veículos, que é uma das mais importantes fontes de metais-traço (SEZGIN et al., 2003), especialmente do $\mathrm{Zn}^{2+}$.

A Figura 22 apresenta a distribuição vertical dos teores de zinco (em ppm) nos diferentes testemunhos (T1, T4, T6 e T8, respectivamente) de sedimento de fundo depositados no lago do barramento Mãe d'Água. Todos os testemunhos apresentaram valores acima do background local (47,4 mg. $\left.\mathrm{kg}^{-1}\right)$, sendo que as ações antrópicas dentro da bacia hidrográfica explicam o aumento na concentração de Zn. Com exceção do T4, que apresenta uma redução nos valores determinados, todos os perfis apresentaram um enriquecimento de $\mathrm{Zn}$ ao longo do processo de deposição sedimentar. De acordo com Alloway (2010), Zn é um elemento bastante notável por estar presente em quantidade relativamente elevadas quando comparado à outros metais, tais como cobre $(\mathrm{Cu})$, chumbo $(\mathrm{Pb})$ e níquel $(\mathrm{Ni})$.

Na Tabela 6 estão os dados tabulados referentes as variações dos valores das concentrações de $\mathrm{Zn}$, que foi apresentado graficamente através dos perfis verticais. O testemunho 1 nas primeiras camadas próximas a superfície apresentou-se como o mais poluído, com 597 mg.kg-1 , em contrapartida o testemunho 6, apresentou a menor concentração no extrato em sua base $\left(25 \mathrm{mg} \cdot \mathrm{kg}^{-1}\right)$. Na análise de dados médios, T6 também aparece como o ponto de deposição em que os sedimentos apresentam menor associação ao metal-traço Zn e, T8, a maior. Os resultados em T1 apresenta valores de concentração em sua superfície que levam ao aumento da média a tendenciado devido a estes valores extremos. 
Tabela 6 - Concentração de Zn (mg.kg-1) nos sedimentos acumulados no Lago Mãe d'Água.

\begin{tabular}{|c|c|c|c|c|}
\hline \multicolumn{5}{|c|}{ Zn (mg.kg-1) } \\
\hline PROFUNDIDADE & T1 & T4 & T6 & T8 \\
\hline 2 & 597 & 103 & 300 & 417 \\
\hline 10 & 317 & 157 & 231 & 418 \\
\hline 18 & 198 & 243 & 214 & 287 \\
\hline 26 & 184 & 251 & 293 & 307 \\
\hline 34 & 174 & 203 & 230 & 225 \\
\hline 42 & 162 & 215 & 202 & 230 \\
\hline 50 & 149 & 205 & 193 & 219 \\
\hline 58 & 118 & 225 & 176 & 186 \\
\hline 66 & & & 154 & 179 \\
\hline 74 & & & 180 & 175 \\
\hline 82 & & & 153 & 171 \\
\hline 90 & & & 176 & 133 \\
\hline 98 & & & 109 & 133 \\
\hline 106 & & & 124 & 113 \\
\hline 114 & & & 124 & \\
\hline 122 & & & 97 & \\
\hline 130 & & & 39 & \\
\hline 138 & & & 34 & \\
\hline 146 & & & 25 & \\
\hline Média & 237 & 200 & 161 & 228 \\
\hline Desvio Padrão & 156,67 & 48,69 & 78,84 & 97,32 \\
\hline Mínimo & 118 & 103 & 25 & 113 \\
\hline Máximo & 597 & 251 & 300 & 418 \\
\hline
\end{tabular}

A concentração de Zn na superfície $(2 \mathrm{~cm})$ de T1 foi de 597 ppm. Este ponto está localizado na porção sul do lago e próximo à margem, sendo sua concentração equivalente a cinco vezes mais do que às determinadas na base deste perfil. Segundo Alloway (2010), o enriquecimento superficial dos solos e sedimentos por $\mathrm{Zn}$ ocorre principalmente através da deposição atmosférica de partículas, fertilização e despejo de lodos de esgoto oriundos da atividade antrópica. Os valores médios de Zn em T1 foram de 237 ppm. O valor mínimo determinado de $\mathrm{Zn}$ foi de 118 ppm na base do perfil, mais próximo à rocha, evidenciando que fatores como erosão e entrada de metais por meio da atividade antrópica são os principais responsáveis pelo enriquecimento deste metal. Segundo Alloway (2010), o zinco é o $24^{\circ}$ elemento mais abundante na Terra e encontra-se presente em rochas ígneas, como o basalto, em concentrações médias de 110 mg. $\mathrm{kg}^{-1}$. 
Os resultados de T1 se assemelham aos determinados por Cardoso (2011) em um ponto de coordenada geográfica muito próximo. Segundo Cardoso (2011), a concentração inicial encontrada na base da amostra foi de $88 \mathrm{mg} \cdot \mathrm{kg}^{-1}$, apresentando-se crescente até o valor 133 mg. $\mathrm{kg}^{-1}$, o que evidencia o constante enriquecimento por zinco neste espaço amostral.

O testemunho 4 (T4) apresentou os menores teores de $\mathrm{Zn}$ em superfície dentre os perfis amostrados, variando entre 103 e $157 \mathrm{ppm}$ nas profundidades de 0 e $10 \mathrm{~cm}$, respectivamente. Os menores valores em superfície em T4 indicam que o processo de enriquecimento não ocorre, e estão relacionados à granulometria que descreve a grande quantidade de materiais grosseiros deste testemunho, visto que a determinação dos teores de metais é realizada apenas na fração fina do mesmo $(<63 \mu \mathrm{m})$. Outro fator que pode influenciar nas quantidades de Zn em T4 é a elevada velocidade de escoamento e vazão d'água neste ponto do barramento.

O testemunho 6 apresentou em média teores de $161 \mathrm{ppm}$ de $\mathrm{Zn}$, sendo o máximo determinado em superfície (300 ppm). Devido a profundidade deste perfil, possivelmente o menor valor de $\mathrm{Zn}$ determinado próximo a rocha $(25 \mathrm{ppm})$ reflita o verdadeiro valor de fundo - também conhecido como background - do barramento. Cardoso (2011) encontrou resultados semelhantes na base do perfil denominado T2, localizado em outra região amostrada do mesmo barramento, mas a semelhança ocorre nas profundidades dos testemunhos e ambos apresentam as mesmas características de enriquecimento, evidenciando que este ponto de coleta abrange, certamente, um significativo período da história de deposição.

O testemunho 8, está localizado próximo ao vertedor. O mesmo possui um comportamento crescente uniforme das concentrações de $\mathrm{Zn}$ da base do perfil para o topo ou superfície. Os valores médios neste ponto foram de 228 ppm, com mínimo de 113 e máximo de $418 \mathrm{ppm}$. O enriquecimento por $\mathrm{Zn}$ em sedimentos presentes nesta região do barramento é evidenciado pelo constante acúmulo dos sedimentos com predomínio de granulometria fina, (silte e argila), estando fortemente associada com a concentração dos metais nos sedimentos, onde, devido à presença da estrutura vertedora de água ocasiona a redução da velocidade do fluxo de escoamento, propiciando assim sua sedimentação. 


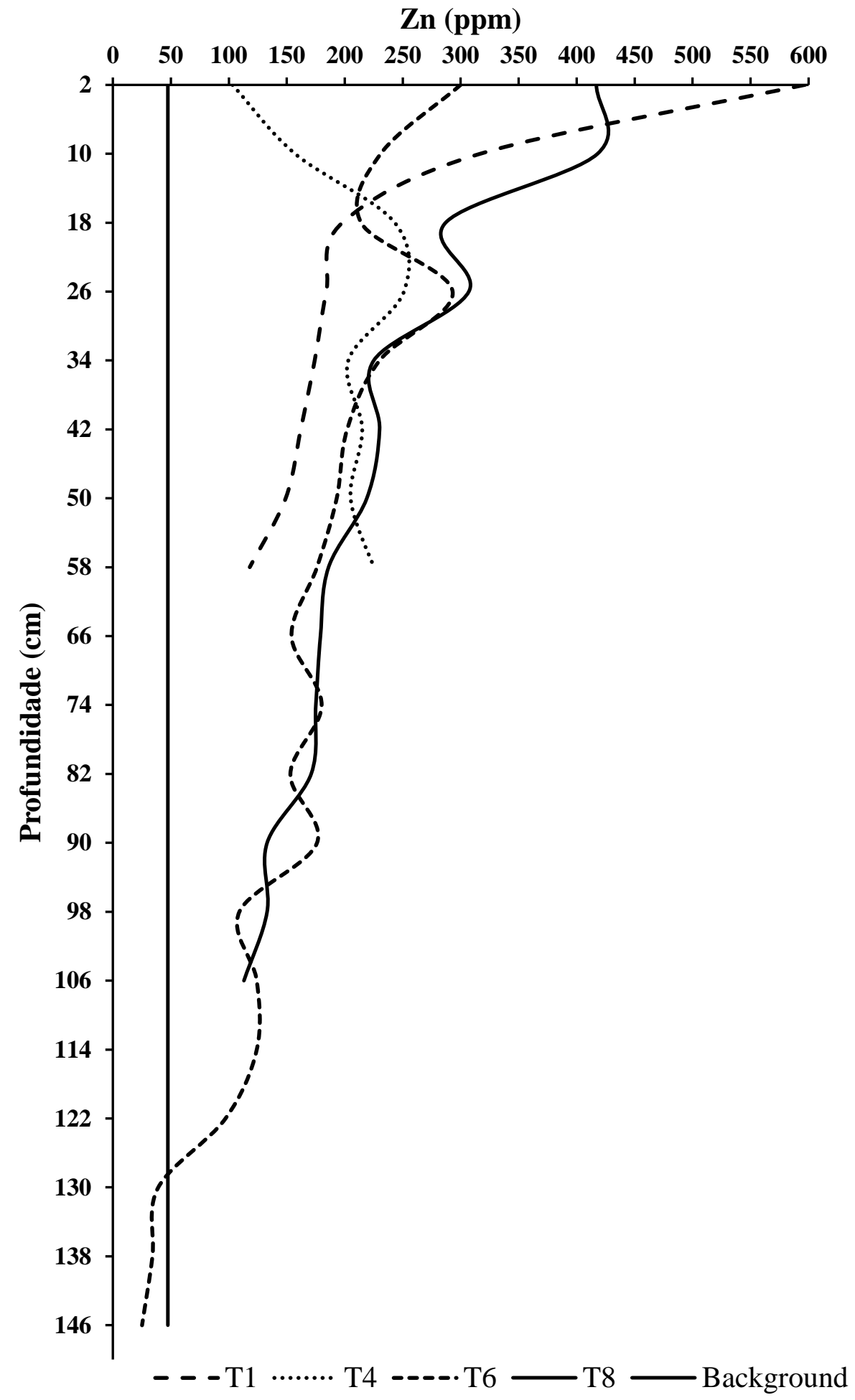

Figura 22 - Distribuição dos teores de zinco em profundidade nos diferentes testemunhos de sedimentos do barramento Mãe d'Água. 
Rubio et al. (2001) descrevem em seu estudo a ocorrência de oscilações no processo de sorção de Zn e atribui à uma migração do zinco para os estratos de sedimentos superiores durante a degradação da matéria orgânica. Assim, como verificado nos testemunhos 1, 6 e 8, temos esta relação com a dinâmica do metal entre a coluna d'água e as partículas de sedimento e o crescimento de sua concentração. Os dados obtidos para as concentrações de zinco, associado aos sedimentos carreados para o lago, permitem inferir o crescimento da poluição da área de estudo, advinda, sobretudo de fontes difusas, advindos da urbanização, que se intensificou nesta bacia nas últimas décadas.

\subsubsection{Concentrações totais de níquel nos testemunhos de sedimentos}

O elemento níquel (Ni) é naturalmente encontrado em todos os tipos de rochas e está presente em toda a pedosfera variando desde quantidades traço até concentrações relativamente altas, quando comparado a outros elementos traço (ALLOWAY, 2010).

Os teores de níquel (Ni) nos testemunhos de sedimento de fundo do barramento Mãe d'Água são apresentados na Figura 23, sendo que todos apresentam valores acima do background local $\left(4,9 \mathrm{mg} \cdot \mathrm{kg}^{-1}\right)$. Tal comportamento deve-se à urbanização da área, visto que processos antropogênicos como a construção de loteamentos, industrialização e lançamentos de resíduos (líquidos, sólidos e gasosos) evidenciam o crescimento gradual das concentrações até a superfície, que representa a deposição mais recente. A exceção ocorreu na base do testemunho 6, com concentrações abaixo do valor de referência local, sendo que o mesmo comportamento foi obtido para o elemento $\mathrm{Zn}$ neste testemunho (Tabela 6). 


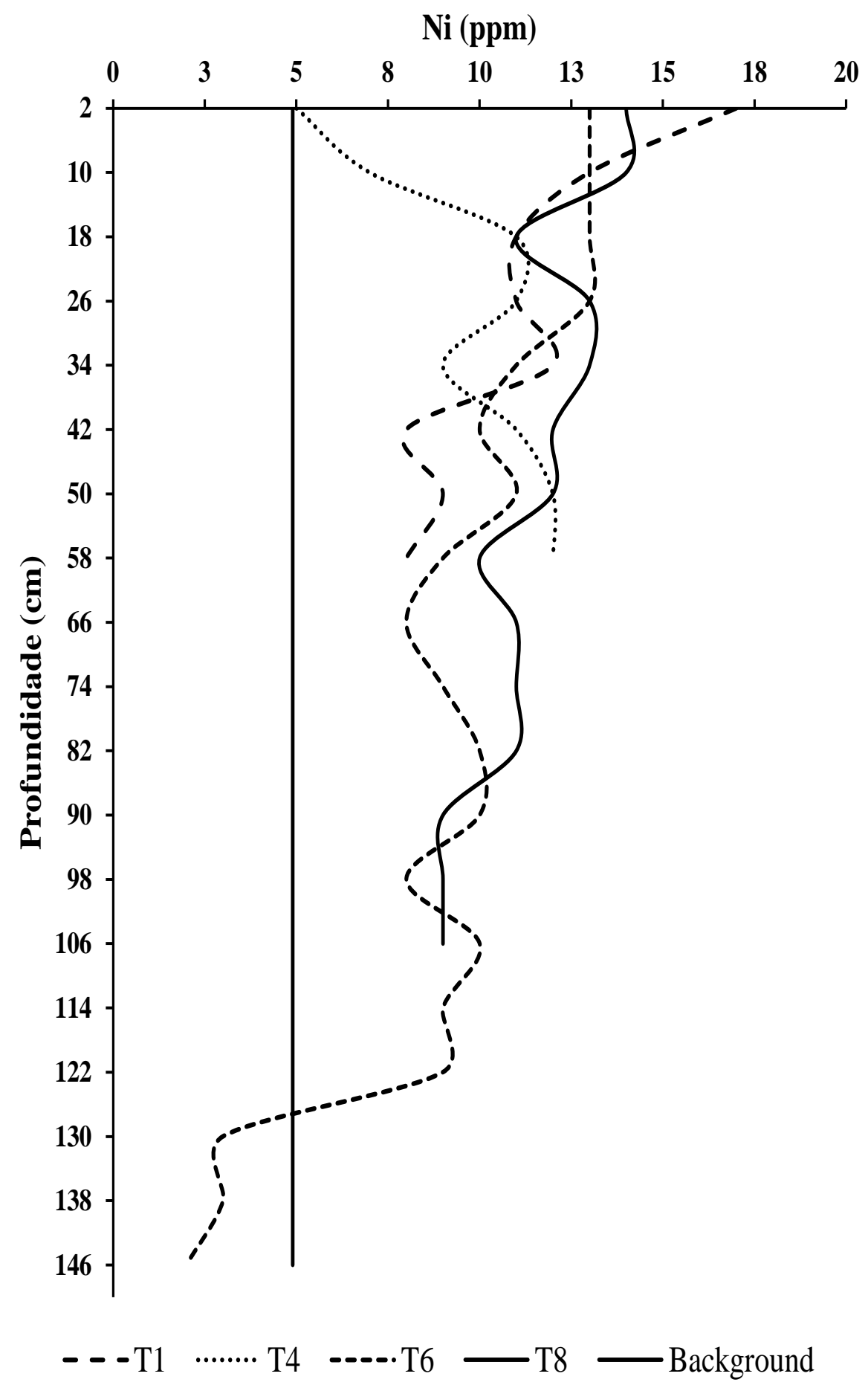

Figura 23 - Distribuição dos teores de níquel (em ppm) em profundidade nos diferentes testemunhos de sedimentos do barramento Mãe d'Água. 
Tabela 7 - Concentração de Ni (mg.kg-1) nos sedimentos acumulados no Lago Mãe d'Água.

\begin{tabular}{ccccc}
\hline \multicolumn{5}{c}{ Ni (mg.kg-1) } \\
\hline PROFUNDIDADE & T1 & T4 & T6 & T8 \\
\hline 2 & 17 & 5 & 13 & 14 \\
10 & 13 & 7 & 13 & 14 \\
18 & 11 & 11 & 13 & 11 \\
26 & 11 & 11 & 13 & 13 \\
34 & 12 & 9 & 11 & 13 \\
42 & 8 & 11 & 10 & 12 \\
50 & 9 & 12 & 11 & 12 \\
58 & 8 & 12 & 9 & 10 \\
66 & & & 8 & 11 \\
74 & & & 9 & 11 \\
82 & & & 10 & 11 \\
90 & & & 10 & 9 \\
98 & & & 8 & 9 \\
106 & & & 10 & 9 \\
114 & & & 9 & \\
122 & & & 9 & \\
130 & & & 3 & \\
138 & & & 3 & \\
146 & & & 2 & \\
\hline Média & 11 & 10 & 9 & 11 \\
\hline Desvio Padrão & 2,997 & 2,54951 & 3,32103 & 1,736803 \\
\hline Mínimo & 8 & 5 & 2 & 9 \\
\hline Máximo & 17 & 12 & 13 & 14 \\
\hline
\end{tabular}

Os dados tabulados referentes as variações das concentrações de Ni são apresentados na Tabela 7. O testemunho 1 nas primeiras camadas próximas a superfície apresentou-se como o mais poluído, com $17 \mathrm{mg} \cdot \mathrm{kg}^{-1}$, em contrapartida o testemunho 4, apresentou a menor concentração no extrato em sua base $\left(12 \mathrm{mg} \cdot \mathrm{kg}^{-1}\right)$. Na análise de dados médios, T6 também aparece como o ponto de deposição em que os sedimentos apresentam menor associação ao metal-traço Ni enquanto o comportamento dos testemunhos, 1, 4 e 8, a maior.

Comparando-se as linhas de distribuição das concentrações de Ni com as de Zn (Figura 22), percebe-se que há um mesmo comportamento em todos os testemunhos. Assim, da mesma forma que o $\mathrm{Zn}$, os testemunhos T1, T6 e T8 apresentam um enriquecimento pelo elemento traço Ni. Fontes antropogênicas têm resultado em um aumento significativo nos níveis de Ni em solos e sedimentos (UTERMANN, DUWEL e NAGEL, 2006). Grande parte das fontes de Ni ocorrem através de emissões industriais e particulados oriundos da combustão de carvoarias 
e petróleo. A aplicação de dejetos e fertilizantes fosfatados também pode ser uma importante fonte de Ni em solos agrícolas (ALLOWAY, 2010).

Os sedimentos mais recentes são aqueles das camadas superiores (representados pela amostra a $2 \mathrm{~cm}$ ), mais próximas a coluna d’água e que apresentam os maiores níveis de concentrações. No testemunho 1, que se encontra a $2 \mathrm{~cm}$ da superfície sedimentar mais recente temos a maior concentração de Ni (17 mg. $\left.\mathrm{kg}^{-1}\right)$. Já em T4, temos um decréscimo na concentração conforme nos aproximamos à superfície. O testemunho T6 apresenta um pico de crescimento significativo na profundidade de $66 \mathrm{~cm}$, partindo de $8 \mathrm{mg} \cdot \mathrm{kg}^{-1}$ a $13 \mathrm{mg} \cdot \mathrm{kg}^{-1}$, mantendo-se estável até a superfície. Em T8 ocorre um comportamento semelhante na profundidade de 122 a $130 \mathrm{~cm}$ ao testemunho T6, atingindo a máxima concentração de 14 mg.kg-1.

De forma geral, a análise das médias das concentrações de Ni nos quatro testemunhos foi de 11, 10, 9 e 11 ppm para T1, T4, T6 e T8, respectivamente. Percebe-se que as concentrações deste metal são baixas em todo o barramento, variando de 2 ppm na base, próximo a rocha de origem do T6, (este valor apresenta-se abaixo das concentrações de background por estar em condições naturais, sem o efeito antropogênico), a 17 ppm na superfície do T1. Cardoso (2011) encontrou concentrações inferiores a determinada no presente estudo, tal fato pode ser explicado pela ocorrência da sedimentação mais recente dos últimos anos, fazendo frente ao processo de urbanização. Segundo Alloway (2010), os teores de níquel na pedosfera são amplamente variáveis $\left(0,2\right.$ a $\left.450 \mathrm{mg} \mathrm{kg}^{-1}\right)$, com média global de $22 \mathrm{mg} \mathrm{kg}^{-1}$. Utermann, Duwel e Nagel (2006), em sua pesquisa determinou as concentrações de fundo de $\mathrm{Ni}$ variando entre 3 e $48 \mathrm{mg} \mathrm{kg}^{-1}$, com menores valores em solos formados de materiais arenosos e maiores teores em solos derivados de rochas vulcânicas.

Mesmo assim, a partir da avaliação do valor de background da área, verifica-se um incremento da presença desse contaminante, advindo de atividades antrópicas, no material carreado pela bacia. Os dados aqui levantados demonstram a existência de interação entre os sedimentos da área e os compostos de níquel, mas expõe, também, uma possível fragilidade dessa interação, visto os padrões oscilantes de associação entre metal-sedimento ao longo da coluna sedimentar. A solubilização de compostos de níquel, é nitidamente correlacionada aos carcinogênicos, apresentando um possível risco ambiental que precisa ser avaliado. 
Ao avaliar as fontes difusas de poluição, é imprescindível observar características de áreas urbanas residenciais e industriais, pois fornecem uma grande gama de poluentes ao ambiente, entre estes se destacam os metais-traço, apresentado no estudo ( $\mathrm{Zn}$ e Ni). A ausência de tratamento dos esgotos e a disposição inadequada destes resíduos fornecem uma grande carga de matéria orgânica, agente fundamental no controle dos processos de sorção e dessorção dos metais aos sedimentos.

\subsection{Teores de matéria orgânica}

\subsubsection{Teores de matéria orgânica correlacionados ao Zinco (Zn)}

O teor de carbono orgânico total, (COT), do sedimento é a somatória do carbono orgânico particulado (COP) e do conteúdo de carbono orgânico dissolvido (COD) (SIMPSON et al., 2005). A determinação dos teores de COT são de extrema importância para se compreender os processos de adsorção de metais no sedimento, visto que a matéria orgânica é um dos principais sítios de ligação dos mesmos em corpos d'água. As Figuras 24 a 27 ilustram a correlação entre as concentrações de Zn e os teores de COT nas amostras de sedimento de fundo do barramento Mãe d'Água.

Todos os testemunhos amostrados apresentam uma correlação positiva entre $\mathrm{Zn}$ e COT. O testemunho 6 apresenta elevada relação entre as duas variáveis, apresenta valor de $\mathrm{R}^{2}$ igual a 0,92 , sendo que as menores concentrações de Zn e COT ocorrem próximo à rocha e aumentam gradativamente em superfície. $O$ fato de haver uma correlação positiva entre as concentrações de $\mathrm{Zn}$ e os teores de COT indica que a matéria orgânica está complexando este elemento no sedimento de fundo. Segundo Abreu et al. (2007), o Zn merece atenção especial em locais com elevado teor de matéria orgânica, pois apresentam elevada afinidade de adsorção à esta fração.

As variações dos teores de COT nos testemunhos de sedimentos de fundo para o Zinco,

apresentado na Figura 17, indica que há uma margem de estabilidade. É importante frisar que essas condições podem ser alteradas de acordo com as condições físicas e químicas, além do 
carreamento e entrada de uma nova carga orgânica, o que irá influenciar sobre os processos de adsorção e sorção dos metais junto a matéria orgânica.

\section{Testemunho 1}

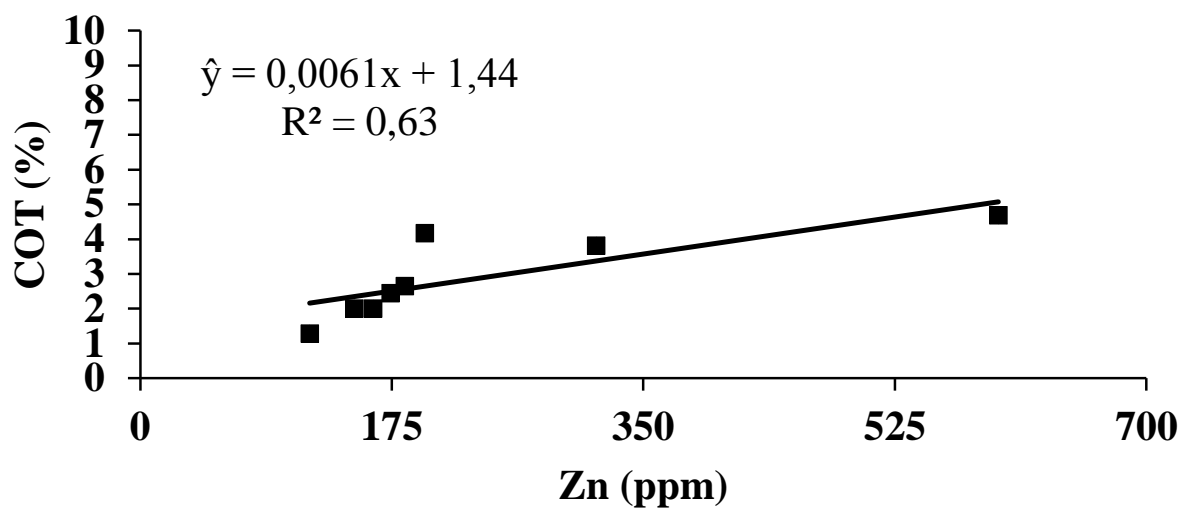

Figura 24 - Regressão linear entre as porcentagens de carbono orgânico total e teores de zinco correspondentes ao testemunho 1 de sedimentos do barramento Mãe d'Água.

\section{Testemunho 4}

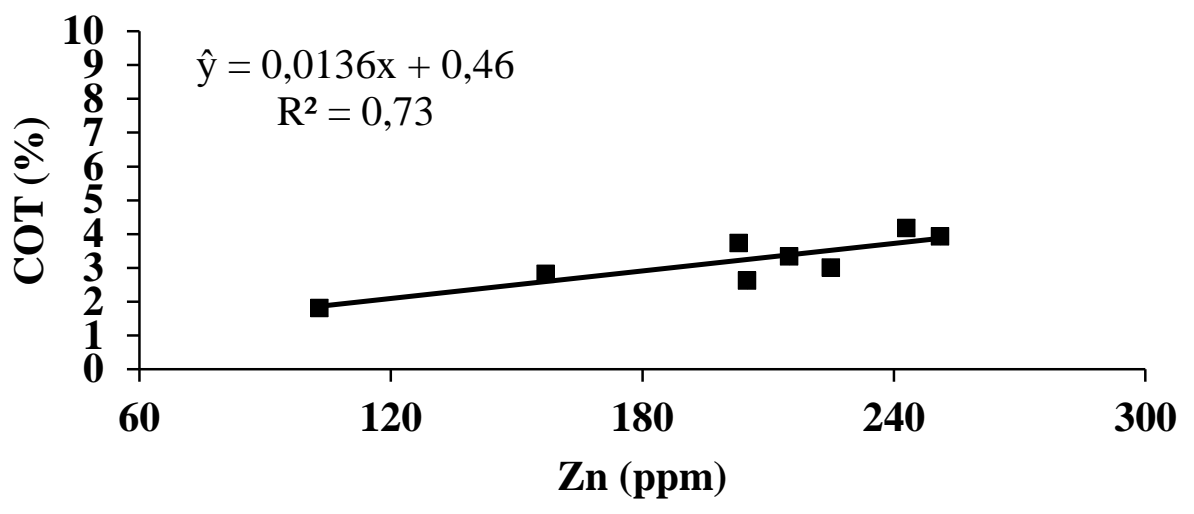

Figura 25 - Regressão linear entre as porcentagens de carbono orgânico total e teores de zinco correspondentes ao testemunho 4 de sedimentos do barramento Mãe d'Água. 


\section{Testemunho 6}

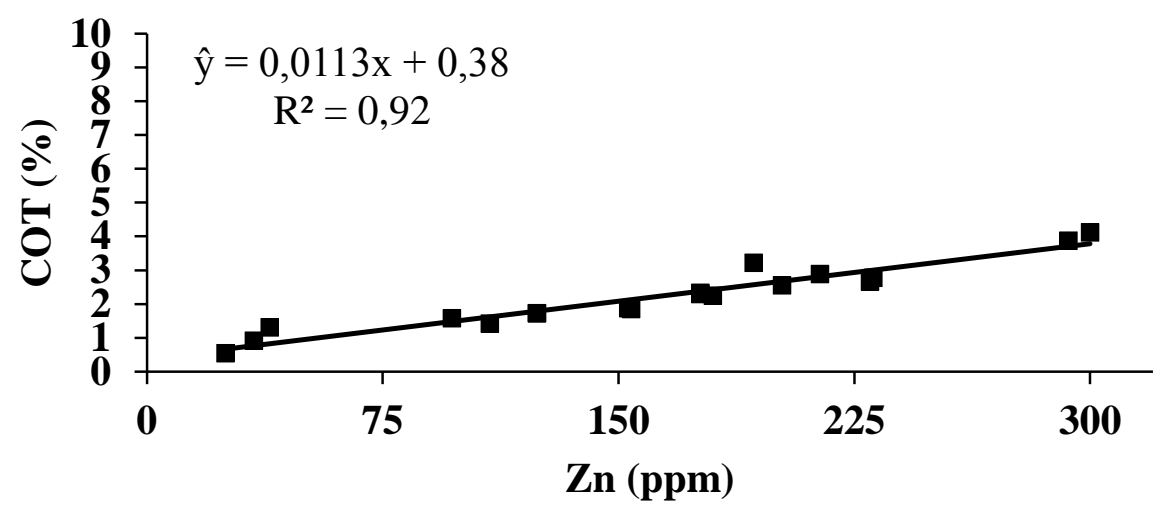

Figura 26 - Regressão linear entre as porcentagens de carbono orgânico total e teores de zinco correspondentes ao testemunho 6 de sedimentos do barramento Mãe d'Água.

\section{Testemunho 8}

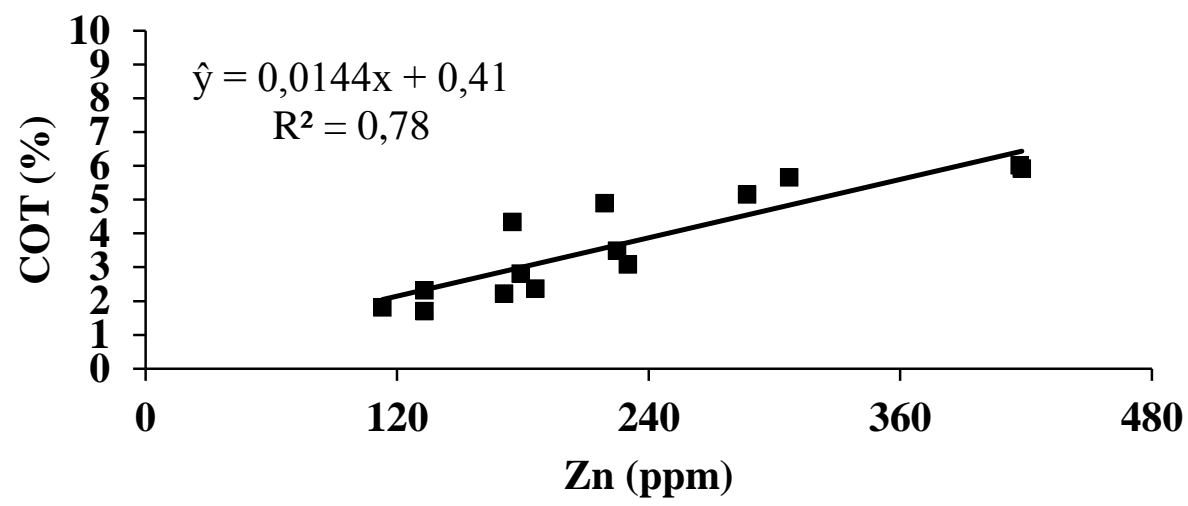

Figura 27 - Regressão linear entre as porcentagens de carbono orgânico total e teores de zinco correspondentes ao testemunho 8 de sedimentos do barramento Mãe d'Água.

Ao analisar os resultados apresentados nas correlações entre COT e os teores de zinco para o testemunho 1, a regressão linear pode estar tendenciosa devido ao ponto extremo estar correlacionado a concentração do zinco de 597 ppm. Este fato deve-se a sua posição em relação a profundidade, localizando-se próximo a superfície. Rubio et al. (2001) descrevem em seu estudo a ocorrência de oscilações no processo de sorção de Zn e atribui em uma migração do 
zinco para os estratos de sedimentos superiores durante a degradação da matéria orgânica. Aliado a isso, pode estar ocorrendo o início de uma contaminação e marcando um novo período de enriquecimento por zinco nos sedimentos advindos da urbanização e carreados até o lago do barramento Mãe D’água.

\subsubsection{Teores de matéria mrgânica correlacionados ao Níquel (Ni)}

As concentrações de Ni no sedimento de fundo do barramento Mãe d'Água também apresentam uma correlação positiva com os teores de COT (Figuras 28 a 31). O T4 apresentou uma menor relação entre ambas variáveis, visto que os teores de COT são pouco variáveis ao longo do processo de deposição, possivelmente devido a velocidade de escoamento d'água neste ponto que está situado sob o ponto de entrada do afluente que abastece o represamento.

Assim como para o Zinco as variações dos teores de carbono orgânico total nos testemunhos de sedimentos de fundo para o níquel apresentam-se abaixo do valor de referência (background) estabelecido por Poleto (2007), apresentado na Figura 17, indicando que há uma margem de estabilidade. É importante frisar que essas condições podem ser alteradas de acordo com as condições físicas e químicas, além do carreamento e entrada de uma nova carga orgânica, efeito antropogênico sobre a bacia, o que irá influenciar sobre os processos de adsorção e sorção dos metais junto a matéria orgânica. 


\section{Testemunho 1}

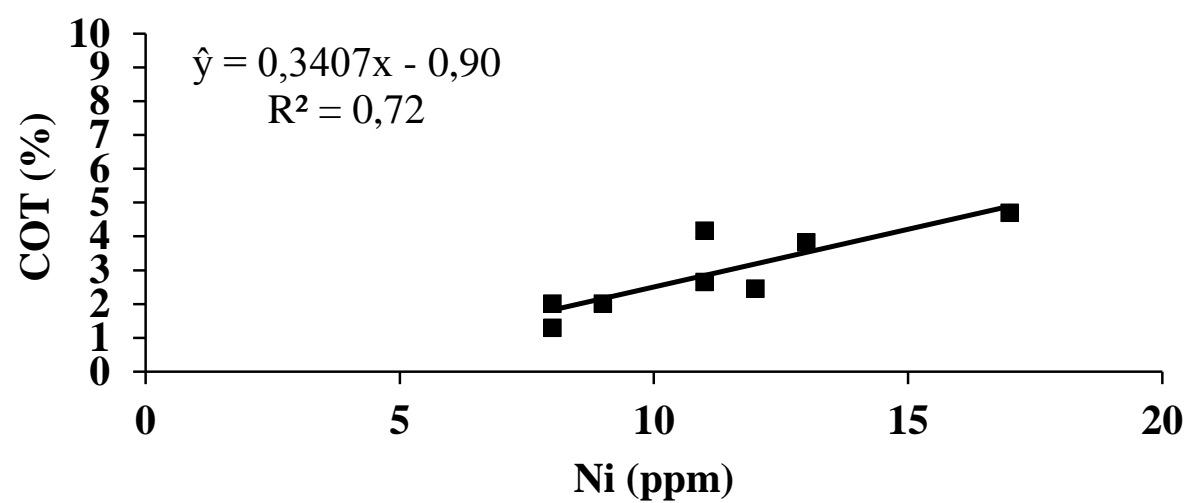

Figura 28 - Regressão linear entre as porcentagens de carbono orgânico total e teores de níquel correspondentes ao testemunho 1 de sedimentos do barramento Mãe d'Água.

\section{Testemunho 4}

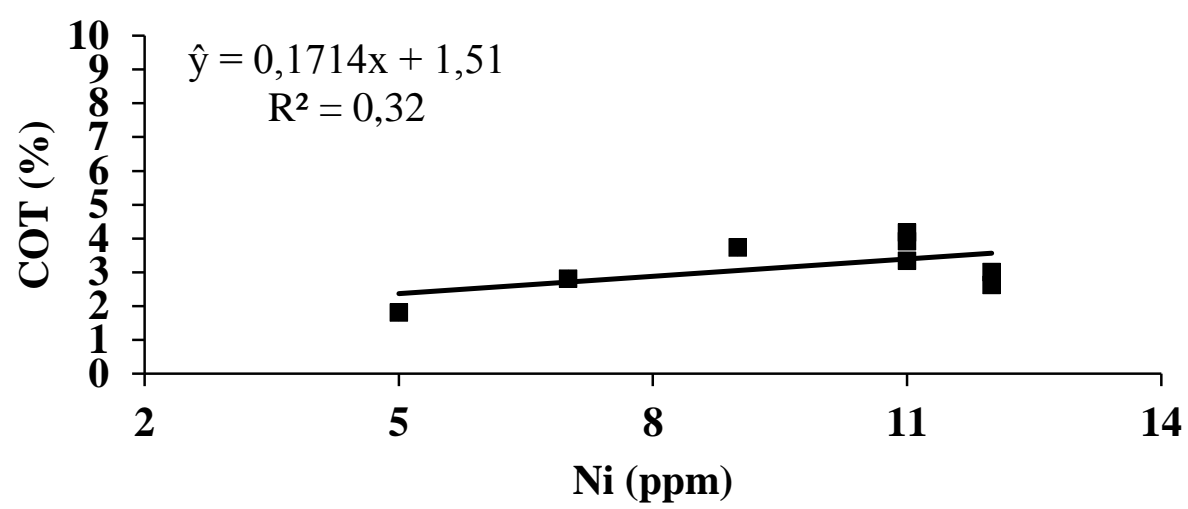

Figura 29 - Regressão linear entre as porcentagens de carbono orgânico total e teores de níquel correspondentes ao testemunho 4 de sedimentos do barramento Mãe d'Água. 


\section{Testemunho 6}

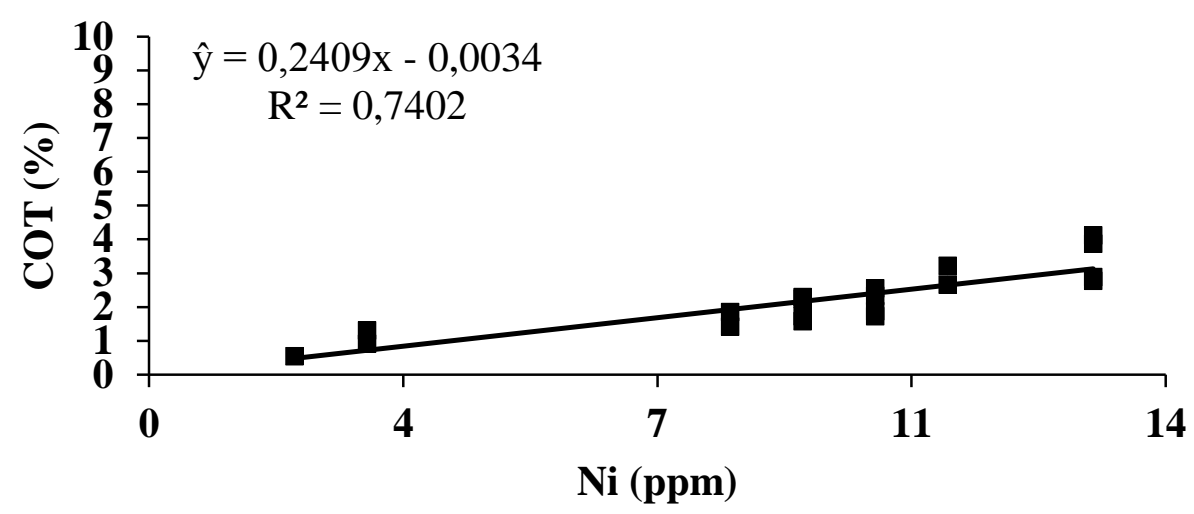

Figura 30 - Regressão linear entre as porcentagens de carbono orgânico total e teores de níquel correspondentes ao testemunho 6 de sedimentos do barramento Mãe d'Água.

\section{Testemunho 8}

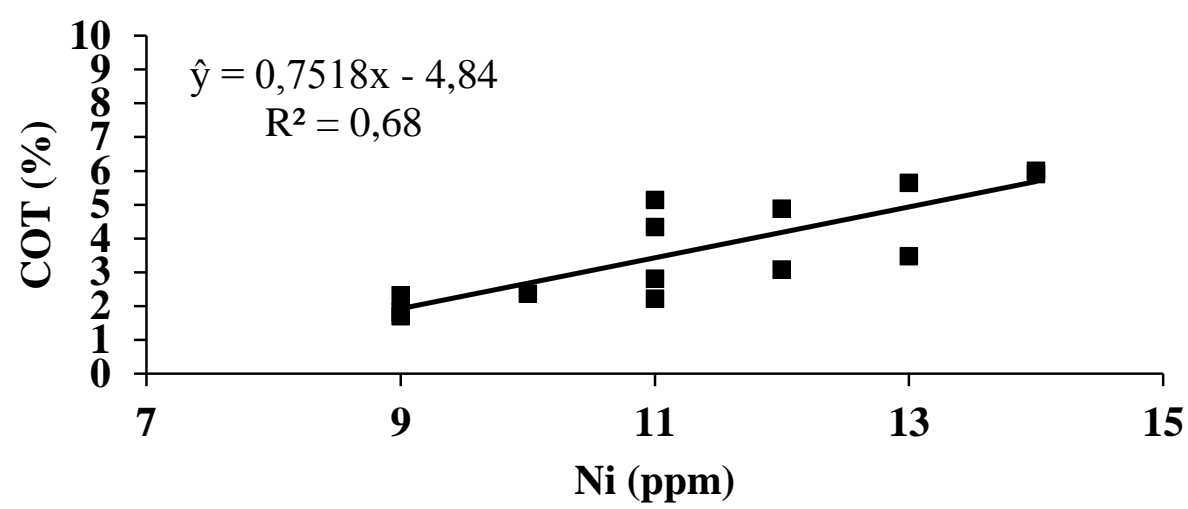

Figura 31 - Regressão linear entre as porcentagens de carbono orgânico total e teores de níquel correspondentes ao testemunho 8 de sedimentos do barramento Mãe d'Água.

Os resultados apresentados nas correlações entre COT e os teores de $\mathrm{Zn}$ e Ni realçam a importância das cargas elétricas nas reações de retenção dos metais, o que é indício do mecanismo de adsorção não-específica ou troca iônica, não descartando, porém, a participação de adsorção específica com o Mn (Matos et al., 2001). A afinidade entre metais pesados em solos e sedimentos já foi relatada em muitos estudos (ZASOSKI e BURAU, 1988; DONG et al., 2000). 
Tal comportamento baseia-se na elevada superfície específica desses minerais microcristalinos e em suas estruturas cristalinas e características de carga. Pelo fato de apresentarem cargas iônicas dependentes do $\mathrm{pH}$ e ponto de carga zero (PCZ) variando de 1,5 a 4,6 , desenvolvem elevado potencial de carga negativo em uma faixa normal de $\mathrm{pH}$ maior que 5, em sedimentos. A adsorção específica de cátions metálicos por óxidos de Mn segue a ordem: $\mathrm{Pb}>\mathrm{Cu}>\mathrm{Mn}>\mathrm{Co}>\mathrm{Zn}>\mathrm{Ni}$, gerando acúmulo de tais íons em concentrações relativamente elevadas nos solos (McKENZIE, 1972, 1980).

A degradação da MO, abundante no material carreado para o lago, é uma fonte para possíveis alterações no $\mathrm{pH}$ e Eh dos sedimentos depositados, influenciando também na mobilidade do níquel no perfil sedimentar. Sabe-se que o Ni é insolúvel em valores de pH superiores a 7, estando predominantemente na forma de hidróxidos de Ni (SUNDERMAN e OSKARSSON, 1991), que por sua vez, podem ser rapidamente incorporados nos sedimentos (BADR et al., 2009).

\section{5. Índice de Geoacumulação}

O Índice de Geoacumulação (Igeo) é outra ferramenta de análise para a comparação do enriquecimento local por metais nos diversos pontos de amostragem, visto que podemos comparar valores da região de estudo (Barramento Mãe D’água) com outra região geoquímica similar pouco impactada utilizando os valores de referências (background). Utilizou-se como background os teores médios de metais obtidos por Poleto (2007), apresentados na Tabela 3. Os valores utilizados para o cálculo do Igeo estão apresentados na Tabela 8. 
Tabela 8- Resultado dos cálculos de Igeo para os testemunhos de sedimentos de fundo. Concentrações de background em (mg.kg-1).

\begin{tabular}{|c|c|c|c|c|c|c|c|c|}
\hline \multicolumn{9}{|c|}{ Valores de I.geo. Para Zn e Ni } \\
\hline \multirow{3}{*}{ PROFUNDIDADE } & \multicolumn{4}{|c|}{ Zn (ppm) } & \multicolumn{4}{|c|}{$\mathrm{Ni}(\mathbf{p p m})$} \\
\hline & \multicolumn{4}{|c|}{ Testemunhos } & \multicolumn{4}{|c|}{ Testemunhos } \\
\hline & $\mathbf{T 1}$ & T4 & T6 & T8 & T1 & T4 & T6 & T8 \\
\hline 2 & 2,53 & 0,44 & 1,27 & 1,77 & 0,70 & 0,20 & 0,53 & 0,57 \\
\hline 10 & 1,34 & 0,66 & 0,98 & 1,77 & 0,53 & 0,29 & 0,53 & 0,57 \\
\hline 18 & 0,84 & 1,03 & 0,91 & 1,22 & 0,45 & 0,45 & 0,53 & 0,45 \\
\hline 26 & 0,78 & 1,06 & 1,24 & 1,30 & 0,45 & 0,45 & 0,53 & 0,53 \\
\hline 34 & 0,74 & 0,86 & 0,97 & 0,95 & 0,49 & 0,37 & 0,45 & 0,53 \\
\hline 42 & 0,69 & 0,91 & 0,86 & 0,97 & 0,33 & 0,45 & 0,41 & 0,49 \\
\hline 50 & 0,63 & 0,87 & 0,82 & 0,93 & 0,37 & 0,49 & 0,45 & 0,49 \\
\hline 58 & 0,50 & 0,95 & 0,75 & 0,79 & 0,33 & 0,49 & 0,37 & 0,41 \\
\hline 66 & & & 0,65 & 0,76 & & & 0,33 & 0,45 \\
\hline 74 & & & 0,76 & 0,74 & & & 0,37 & 0,45 \\
\hline 82 & & & 0,65 & 0,72 & & & 0,41 & 0,45 \\
\hline 90 & & & 0,75 & 0,56 & & & 0,41 & 0,37 \\
\hline 98 & & & 0,46 & 0,56 & & & 0,33 & 0,37 \\
\hline 106 & & & 0,53 & 0,48 & & & 0,41 & 0,37 \\
\hline 114 & & & 0,53 & & & & 0,37 & \\
\hline 122 & & & 0,41 & & & & 0,37 & \\
\hline 130 & & & 0,17 & & & & 0,12 & \\
\hline 138 & & & 0,14 & & & & 0,12 & \\
\hline 146 & & & 0,11 & & & & 0,08 & \\
\hline Background & \multicolumn{4}{|c|}{47,4} & \multicolumn{4}{|c|}{4,9} \\
\hline
\end{tabular}

Conforme ilustra a Tabela 8, a grande maioria dos valores de Igeo (78\% e $80 \%)$ apresentaram valores próximos a zero. Este fato nos permite classificar os sedimentos como não poluídos ou moderadamente poluído (Igeo < 0 , ver Tabela 1), em relação aos metais zinco e níquel. Os valores que se apresentaram com a classificação de 1 segundo Müller (1981), sendo $16 \%$ para zinco e $20 \%$ para níquel, do total correspondente aos metais, sob a análises estão enquadrados em não poluído a moderadamente poluído. Deve se atentar a superfície do testemunho 1 que apresenta um valor de $2,53 \mathrm{ppm}$ e é classificado como moderadamente à fortemente poluído, este fato, ainda pode significar que, esteja ocorrendo um enriquecimento do metal zinco na superfície dos sedimentos, caracterizando a entrada do metal através do carreamento dos sedimentos oriundos da bacia hidrográfica a montante deste ponto em questão. 
As Figuras 32 e 33 representam graficamente a classificação do índice de geoacumulação para zinco e níquel variando conforme a profundidade. É possível verificar de uma forma clara e objetiva que os valores se encontram dentro de faixas classificatórias estabelecidas de acordo com Müller (1981), e como apresentado nas Figuras 22 e 23, que relacionam a concentração dos metais com a profundidade, sua correlação com a contaminação e com enriquecimento dos sedimentos se dá nas porções próximas a superfície, apresentando conformidade entre os resultados estabelecidos. 

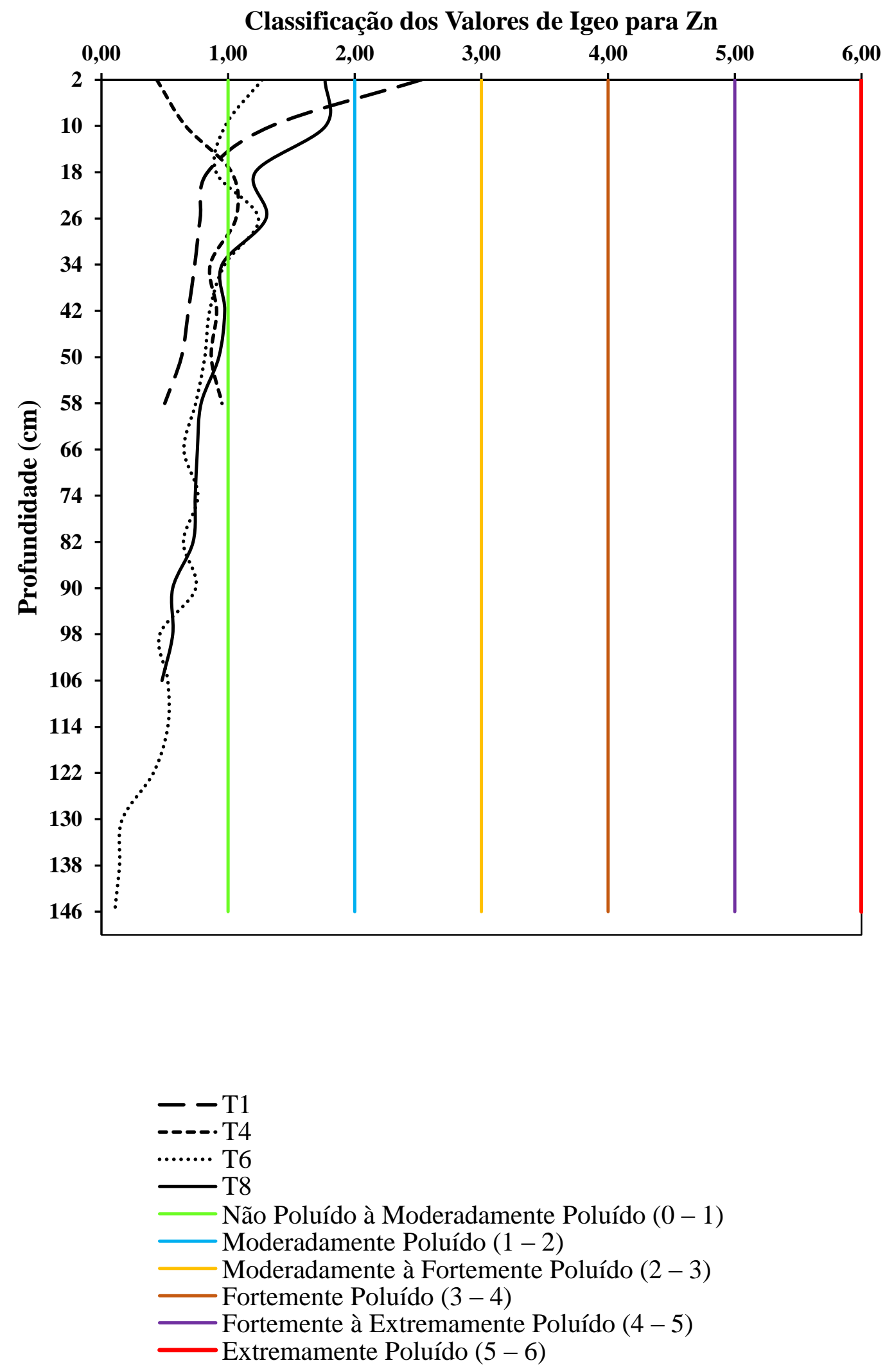

Figura 32- Classificação dos valores do Igeo para Zn em profundidade nos diferentes testemunhos de sedimentos do barramento Mãe d'Água. 

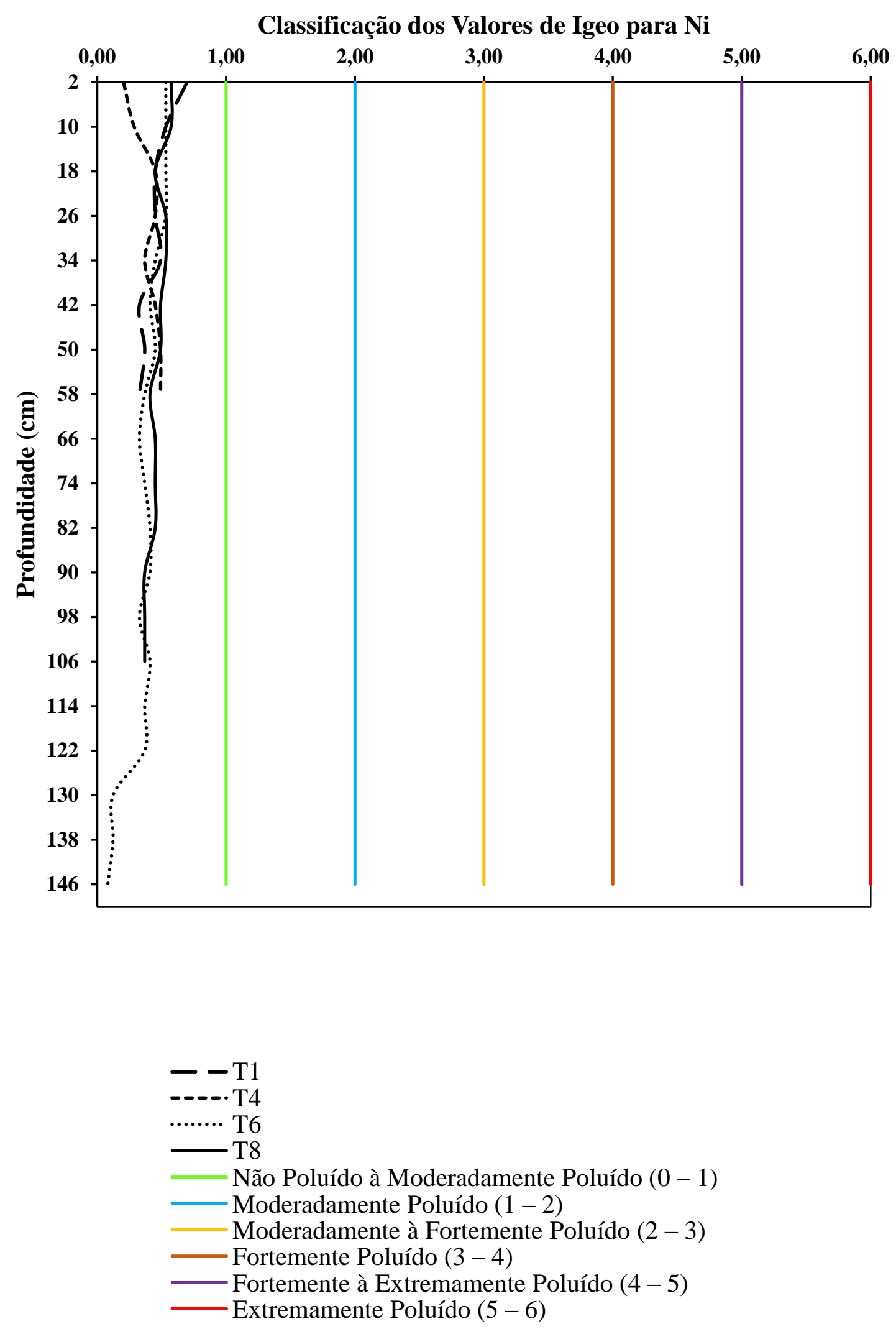

Figura 33- Classificação dos valores do Igeo para Ni em profundidade nos diferentes testemunhos de sedimentos do barramento Mãe d’Água. 
Dos resultados obtidos as classificações preocupantes foram apenas para o metal zinco próximo a superfícies sendo, no testemunho 1, na profundidade de $2 \mathrm{~cm}$ e de 2 a $10 \mathrm{~cm}$ para testemunho 8. Nestas profundidades, o Igeo classifica como moderadamente a altamente poluído em T1 e sua porcentagem foi de $2 \%$ do total dos pontos amostrados e classificação do Igeo de moderadamente poluído para T8 com porcentagem de 4\% do total amostrado. Desta forma, há a probabilidade da contaminação provocada por este metal nestes pontos (superfície de T1 e T8) em relação aos demais, que foram classificados como não poluídos a moderadamente poluídos $(0<$ Igeo $<1)$.

Os valores médios de zinco e níquel encontrados por Martínez e Poleto (2012), ao realizar um estudo de caso sobre os sedimentos urbanos coletados na cidade de Porto Alegre apresentaram valores em ordem crescente de $\mathrm{Zn}(3,04)<\mathrm{Ni}(3,14)$, classificando como fortemente poluído. Por serem sedimentos de origem urbana, pode se pensar no carreamento desses metais para o corpo hídrico mais próximo, causando o enriquecimento dos sedimentos e contaminação do ecossistema lacustre.

Shi et al. (2010) encontraram em uma região metropolitana da China os seguintes valores do Igeo representados em ordem crescente, $\mathrm{Ni}(0,37)<\mathrm{Zn}(2,44)$. Comparando estes valores com os obtidos por Martínez (2012), é notório que a produção dos sedimentos contaminados em Porto Alegre é alarmante, pois os níveis encontram-se altos e com o carreamento desses sedimentos fica evidente a provável contaminação do recurso hídrico e de seu ecossistema através do passível ambiental gerado nos centros urbanos.

Observando os resultados do índice de geoacumulação deste estudo nota-se que o enriquecimento por metais nas camadas superficiais pode ser justificado pela alta produção e carreamento desses sedimentos contaminados ao recurso hídrico. A bacia hidrográfica onde encontra-se o lago do barramento Mãe D’água está sendo altamente urbanizada nas últimas décadas, o que acaba refletindo de forma negativa sobre os corpos d'água ali presentes. 


\section{CONCLUSÃO}

O estudo e caracterização da granulometria dos sedimentos em deposição sobre o barramento Mãe D’água mostrou-se suscetível à contaminação através da poluição advinda de zonas urbanizadas, visto que nas camadas mais próximas a superfície nos testemunhos 1,6 e 8 foram identificadas áreas com predominância da fração de sedimentos finos $(>63 \mu \mathrm{m})$. Estes requerem maior atenção devido a maior propensão a contaminação e afinidade aos metais.

Os metais $\mathrm{Zn}$ e $\mathrm{Ni}$, apresentaram concentrações elevadas nas frações recentes da sedimentação. Assim, na superfície dos testemunhos 1, 6 e 8 obteve-se as maiores concentrações destes metais, evidenciando a existência do enriquecimento dos sedimentos por esses elementos, sendo que todos os estratos da coluna sedimentar analisados apresentaram concentrações acima do valor de background. Este comportamento é evidenciado à urbanização da área, visto que processos antropogênicos favorecem o crescimento gradual das concentrações até a superfície, que representa a deposição mais recente.

Os teores de matéria orgânica quando correlacionados as concentrações de $\mathrm{Zn}$ apresentaram de forma mais perceptiva e contínua quando comparada com o $\mathrm{Ni}$, mostrando o crescente enriquecimento nos testemunhos analisados, confirmando a alta afinidade deste elemento à sedimentos compostos de fração orgânica, abundante na área devido a inexistência de tratamento de esgotos.

O índice de geoacumulação demonstra que a maior parte das concentrações de metais em profundidade encontra-se como "não poluída". Porém, fica eminente o enriquecimento nas superfícies, onde a classificação através do Igeo variou entre moderadamente à fortemente poluído, confirmando que as modificações antrópicas ocorridas nas últimas décadas nesta bacia podem implicar em diversos passivos ambientais como a contaminação deste ecossistema lacustre. Este tipo de estudo deve ser acompanhado de análises de variabilidade temporal e espacial das concentrações dos metais em amostras de sedimentos, como foi realizado, para que permita sugerir novas alternativas úteis no gerenciamento dos sedimentos, com o intuito de reduzir os riscos que estes contaminantes podem representar a saúde da população e ao ecossistema presente na bacia hidrográfica. 
As etapas envolvidas neste estudo, bem como os resultados satisfatórios obtidos caracterizam a importância das pesquisas ambientais. Este estudo através das análises realizadas, visa ou auxilia em uma melhor gestão para os recursos hídricos e o planejamentos e gestão da bacia hidrográfica, uma vez que, seu potencial hídrico é de suma importância para os habitantes que passam extrair e consumir esta água ou mesmo o lazer no local.

Esta pesquisa também oferece um auxílio em uma possível atualização no plano diretor da cidade, ordenando melhor a urbanização do local oferecendo uma melhor infraestrutura juntamente com políticas sócio-ambientais e um Plano de Recuperação de áreas Degradadas (PRAD), afim de minimizar os passivos ambientais gerados na bacia do barramento Mãe D’água, revelando soluções e métodos para a contenção da erosão, carreamento de sedimentos, assoreamento e drenagem urbana na região. 


\section{BIBLIOGRAFIA}

ABREU, C.A. et al. Micronutrientes. In: NOVAIS, R.F. et al. Fertilidade do Solo. Viçosa: Sociedade Brasileira de Ciência do Solo, 2007. Cap.11, p.645-736.,

ABREU, M. F.; ANDRADE, J. C.; FALCÃO, A. A. Protocolos de análises químicas. In: ANDRADE, J. C.; ABREU, M. F. (Eds). Campinas: Instituto Agronômico, p. 121- 158. 2006.

ABNT - Associação Brasileira de Normas Técnicas; Rochas e solos. NBR 6502/95, Rio de Janeiro, 1995.

ABNT - Associação Brasileira de Normas Técnicas; análise granulométrica solo. NBR 7181/84. Rio de Janeiro, 1984.

ADACHI, K.; TAINOSHO, Y. 2005. Single Particle Characterization of Size-fractionated Road Sediments. Applied Geochemistry. v.20. n.5. pp.849-859.

ALLOWAY, B.J. Heavy metals in soils. New York. John Wiley\& Sons, p. 339, 1990.

ALLOWAY, B.J. (2010) Heavy metals in soils: Trace Metals and Metalloids in Soils and their Bioavailability. 3th Ed. John Wiley and Sons, Inc. New York.

ALVES, L. C. 2000. Perspectiva sócio-ambiental na Vila Santa Isabel, Viamão - RS: estudo de caso. In: Ambiente e Lugar no Urbano: A Grande Porto Alegre. Suertegaray, D. M. A.; Basso, L. A.; Verdum, R. Porto Alegre: UFRGS. pp.135-159.

ARMANNSSON, H.; BURTON, J.D.; JONES, G.B.; KNAP, A.H. Trace metals and hydrocarbons in sediments from the Dothampton Water Region, with particular reference to the influence of oil refinery effluent. Marine Environmental Research, v. 15, p. 31-44.1985. 
BADR, N.B. E.; EL-FIKY, A. A; MOSTAFA, A. R.; AL-MUR, B. A. 2009. Metal pollution records in core sediments of some Red Sea coastal areas, Kingdom of Saudi Arabia. Environmental Monitoring and Assessment. v. 155. pp. 509-526.

BAIRD, C. Química ambiental. 2.ed. Porto Alegre: Bookman, 2002. 622p.

OBERNER, E. K.; BERNER, R .A. 1996. Global Environment: water, air and geochemical cycles. [S.1.:s.n.]. Prentice Hall.

BOnETTO, M. Personalidades: Mainar Bonetto. Revista Santa Isabel. Disponível em: <http://www.vilasantaisabel.com.br/persona-010.htm>. Acesso em: 17 jun. 2014.

BORDAS, J. L.; LANNA, H. E.; E SEMMELMANN, F. R. 1988. Evaluation dês risques d' érosion ET de sédimentation au Brésil a partir de bilans sedimentologiques rudimentaires. IAHS publ. N.174, Porto Alegre: Symp. p.359-69.

Buykx, S. E. J.; Bleijenberg, M.; Van den Hoop, M. A. G. T.; Loch, J. P. G. 2000. The Effect of Oxidation and Acidification on the Speciation of Heavy Metals in Sulfide-Rich Freshwater Sediments Using a Sequential Extraction Procedure. Journal Environmental Monitoring. v.2. pp.23-27.

CABELO-GARCIA, A.; PREGO, R. Land inputs, behaviour and contamination levels of copper in a ria estuary (NW Spain). Marine Environmental Research. v. 56, p. 403-422, 2003.

CARDOSO, A. R. (2011). Evolução urbana e o enriquecimento de sedimentos por metaistraço na barragem Mãe d'Água, sub-bacia do Arroio Dilúvio, RMPA/RS. Porto Alegre. Dissertação (Mestrado) - Universidade Federal do Rio Grande do Sul. 87 f

CARVAlHO, N. O. Hidrossedimentologia Prática, Rio de Janeiro/RJ: CPRM, 1994.

CARVALHO, N. O. 2008. Hidrossedimentologia prática. Rio de Janeiro: Interciência, $2^{\mathrm{a}}$ Ed. $599 \mathrm{p}$. 
CHARLESWORTH, S. M.; EVERETT, M.; MCCARTHY, R.; ORDÓÑEZ, A.; MIGUEL, E. 2003. A Comparative Study of Heavy Metal Concentration and Distribution in Deposited Street Dusts in a Large and a Small Urban Area: Birmingham and Conventry, West Midlands, UK. Environment International. v.29. pp.563-573.

CHRISTOFOLETTI, A. Geomorfologia Fluvial. v.1. São Paulo: Edgard Blücher, 1981.

DIAS, J. C.; LIMA, W. N.; Comparação de Métodos para a Determinação de Matéria Orgânica em Amostras Ambientais. Revista Científica da UFPA, v.04, p. 84. abril 2004.

DONG, D.; NELSON, Y.M.; SHULER, L.W.M.; GHIORSE, W.C. Adsorption of Pb and Cd onto metal oxides and organic material in natural saurface coatings as determined by selective extrations: new evidence for the importance of Mn and Fe oxides. Water Research, v.34, n.2, p.427-436, 2000.

ELDER, J. F. 1988. Metal Biogeochemistry in Surface-Water Systems - A Review of Principles and Concepts. U.S. Geological Survey Circular 1013. 50p.

ESCOBAR, E, (2014). História da Grande Santa Isabel: Ao pé do Morro Santana. Disponível em: < http://www.vilasantaisabel.com.br/historia.htm>. Acesso em: 15 jun. 2014.

ESTEVES, F. A. Elementos Traço. In: Fundamentos de Limnologia. Esteves, F. A. Rio de Janeiro: Interciência. 1998. pp.285-299.

FADIGAS, S. F. AMARAL-SOBRINHO, N. M. B, ANJOS, L. H. C., FREIXO, A. A. et al. Concentrações naturais de metais pesados em algumas classes de solos brasileiros. Bragantia, Campinas, v. 61, n. 2, 151-159, 2002.

FOSTER, G. R. Modeling the erosion process. In: HAAN, C. T.; JOHNSON, H. P.; BRAKENSIEK, D. L. Hydrologic Modeling of small watersheds. St. Joseph: ASAE, 1982. p. 297-380.

FORStner, U.; WITtMann, G.T.W.; Metal Pollution in the Aquatic Environment; Springer-Verlag: Berlin, 1981, p. 931. 
FRANCHI, J. G. A utilização de turfa como adsorvente de metais pesados. O exemplo da contaminação da bacia do Rio Ribeira de Iguape por chumbo e metais associados [tese]. São Paulo: USP, Instituto de Geociências, 2004.

FREITAS, C. 2005. Caracterização ecológica da represa Mãe d'Água, Campus do Vale da UFRGS, Morro Santana, Porto Alegre - RS (Brasil). Dissertação (Mestrado) Universidade Federal do Rio Grande do Sul. 54p.

FUJIMOTO, N. S. V. M. 2001. Análise ambiental urbana na área metropolitana de Porto Alegre - RS: sub-bacia hidrográfica do Arroio Dilúvio. São Paulo. Tese (Doutorado) Universidade de São Paulo. 236 f.

GARLIPP, A. B. Variação Espacial e Sazonal de Elementos Maiores e Traços no Estuário do Rio Curimataú (RN), Através de Dados Geoquímicos e de Sensoriamento Remoto. 2006. 110f. Tese (Doutorado) - Universidade Federal do Rio Grande do Norte - UFRN, Natal, 2006.

GERAKIS, A.; BAER, B. A computer program for soil textural classification. Soil Science Society of America Journal, v. 63, p. 807-808, 1999.

GÓIS LEAL, G.C.S; FARIAS, M. S. S.; ARAUJO, A.F. O processo de industrialização e seus impactos no meio ambiente urbano. QUALIT @S Revista Eletrônica. ISSN 1677-4280 v.07. $n^{0} 1,2008$.

GUILHERME, L. R. G., MARQUES, J. J., PIERANGELI, M. A. P., ZULIANI, D. Q., CAMPOS, M. L., e $\mathrm{MARCHI}, \mathrm{G}$. Elementos-traço em solos e sistemas aquáticos. Rev. Bras. Ciênc. Solo, p. 345$390,2005$.

HANESH, M.; SCHOLGER, R. Mapping of heavy metal loadings in soils by means of magnetic susceptibility measurements. Environmental Geology, p. 857-870, 2002.

HARPER, K.; OLIVEIRA, A. P. Determinação de Elementos-Traço em Solos e Lodos de Esgoto por ICP OES. Revista Analytica, n.23, p.53-59, junho/julho 2006 
HEDGE, L.H.; KNOTT, N.A.; JOHNSTON, E.L. 2009. Dredging related metal bioaccumulation in oysters. Marine Pollution Bulletin. v. 58. pp. 832-840.

HOROWITZ, A. J. 1991. A primer on sediment-trace element chemistry. 2 ed. Chelsea, EUA: Lewis Publishers. 136p.

IAEA - TECDOC - 1360. Collection and preparation of bottom sediment samples for analysis of radionuclides and trace elements. International Atomic Energy Agency IAEA, 2003.

KABATA-PENDIAS, A.; PENDIAS, H. Trace elements in soils and plants. 3. ed. Londres, 2001.

KINGSTON, H. M.; JASSIE, J., Introduction to microwave sample preparation: theory and practice", L.B. (ed.) Washington, USA., American Chemical Society, p 248, 1986.

KÖPPEN, W.; GEIGER, R. 1928.Klimate der Erde. Gotha: Verlag Justus Perthes. Disponível em: < http://klima-der-erde.de/koeppen.html> Acesso em: 10 mar. 2014.

KRONE, R. B. Flume studies of the transport of sediment in estuarial processes, final report. Berkeley: Hydraulic Engineering Laboratory and Sanitary Engineering Research Laboratory, University of California, 1962.

LEMES, M. J. de L. Avaliação de Metais e Elementos-traço em Águas e Sedimentos das Bacias Hidrográficas dos Rios Mogiguaçu e Pardo, São Paulo. São Paulo. Dissertação (Mestrado) - Universidade de São Paulo/IPEN. 248 f. 2001.

LICK W.; LICK J.; ZIEGLER C. K. Flocculation and its effect on the vertical transport of finegained sediments. Hydrobiologia, v. 235, p. 1-16, 1992.

LIVI, F. P. Elementos do Clima. In: Menegat, R.; Porto, M. L.; Carraro, C. C.; FERNANDES, L. A. D. (org) Atlas Ambiental de Porto Alegre. 2. ed. Porto Alegre: Ed. UFRGS. 1999. pp.7072. 
MallmanN, F. J. K. (2009). Simulação do Transporte Vertical de Zinco, Chumbo e Cobre em Solos Contaminados. Dissertação (Mestrado) Universidade Federal de Santa Maria. $147 f$.

MANAHAN, S. E. Environmental Chemistry. Boca Raton: Lewis Publishers, 7th. ed. 2000. $898 \mathrm{p}$.

MARIANI, C. F. 2006. Reservatório Rio Grande: Caracterização Limnológica da Água e Biodisponibilidade de Metais Traço no Sedimento. Dissertação (Mestrado) Universidade de São Paulo. 138f.

MARTINEZ, L.L.G. 2010. Distribuição de Poluição Difusa por Sedimentos Urbanos em Áreas Impermeáveis de Porto Alegre-RS. Porto Alegre. Dissertação (Mestrado). Universidade Federal do Rio Grande do Sul. 97f.

MARTINEZ, L. L. G. ; POLETO, Cristiano . Poluição difusa associada a metais pesados em sedimentos urbanos na cidade de porto alegre: aplicação do índice de geoacumulação (igeo) para estudo de caso. In: Cristiano Poleto; Adelmo Lowe Pletsch; Eloy Lemos de Mello; Newton de Oliveira Carvalho. (Org.). X Encontro Nacional de Engenharia de Sedimentos: Artigos Selecionados. 1ed.Porto Alegre: ABRH, 2012, v. , p. 3-18.

MATOS, A.T.; FONTES, M.P.F.; COSTA, L.M.; MARTINEZ, M.A. Mobility of heavy metals as related to soil chemical and mineralogical characteristics of Brazilian soils. Environmental Pollution, v.111, p.429-435, 2001.

McKENZIE, R.M. The adsorption of lead and other heavy metals on oxides of manganese and iron. Australian Journal of Soil Research, v.18, p.61-73, 1980.

McKENZIE, R.M. The sorption of some heavy metals by lower oxides and hydroxides of manganese. Geoderma, v.8, p.29-35, 1972. 
MEDEIROS, R. L. S.; Avaliação das Condições Química e Física dos Sedimentos do Estuário Jundiaí-Potengi. Dissertação (Mestrado) - Universidade Federal do Rio Grande do Norte - UFRN, Natal, 2009.

METRE, P. C. V.; MAHLER, B. J. The contribution of particles washed from rooftops to contaminantes loading to urban streams. Chemosphere, v. 52, p.1727-1741,2003.

MEURER, E. J.; RHEINHEIMER, D.; BISSANI, C. A. 2010 Fenômeno de Sorção em SolosIn: MEURER, E. J. (Ed) Fundamentos de Química do Solo. Porto Alegre: Genesis. pp. 131-181.

Müller, G., 1981. Die Schwermetallbelstung der sedimente des Neckars und seiner Nebenflusse: eine Bestandsaufnahme. Chemiker-Zeitung 105, 157-164.

MIRANDA, L. B.; CASTRO, B. M.; KJERFVE, B.; Princípios de Oceanografia Física de Estuários. Editora da Universidade de São Paulo: Brasil, 2002. 414p.

MOZETO, A.A.O. Manejo de qualidade da água e da dinâmica do sedimento e do particulado da Represa do Guarapiranga e do Rio Grande, RMSP, São Carlos, Universidade Federal de São Carlos, projeto RHAE, 1996.

MOZETO, A.A. Coleta de sedimentos de ambientes aquáticos continentais, extração de águas intersticiais e determinação granulométrica. In: MOZETO, A. A.; UMBUZEIRO, G. A.; JARDIM, W. F. Métodos de coleta, análises fisico-químicas e ensaios biológicos e ecotoxicológicos de sedimentos de água doce - Projeto Qualised. Cubo Multimidia, São Carlos, 2006. 26p.

MÜLLER, G.; GRIMMER, G. BÖHNKE H. 1977. Sedimentary Record of Heavy Metals and Polycyclic Aromatic Hydrocarbons in Lake Constance. Naturwissenschaften. v. 64, pp.427-431.

NASCIMENTO, M. C.; SOARES, V. P.; RIBEIRO, C. A. A. S; SILVA, E. 2005. Delimitação automática de Áreas de Preservação Permanente (APP) e identificação de conflito de uso 
da terra na bacia hidrográfica do rio Alegre. In: Simpósio brasileiro de sensoriamento remoto, 12. Goiânia. Anais. Goiânia, pp. 2289-2296.

NORDIN, C. F.; McQUIVEY, R. S. Suspended load. In : SHEN, H. W. River mechanics. Fort Collins, 1971.

OMEE ( Ontario Ministry of the Evironment and Energy). 1993. Guidelines for the Protection and Management of Aquatic Sediment Quality in Ontario. Toronto: Ontario Ministry of the Environment and Energy.

OLIVEIRA, S. A.; TAVARES, S. R. L.; MAHLER, C. F. Avaliação de diferentes métodos de extração de metais pesados em solos contaminados provenientes de atividades de galvanoplastia. In: FERTBIO, 2008. Londrina. Resumos. CD-Rom.

PARDOS, M.; BENNINGHOFF, C.; ALENCASTRO, L. F.; WILDI, W. 2004. The Impact of a Sewage Treatment Plant's Effluent on Sediment Quality in a Small Bay in Lake Geneva (Switzerland-France), Part I: Spatial Distribution of Contaminants and the Potencial for Biological Impacts. Lakes\&Research an Management. v.9. pp.41-52.

PETRY, Cristiane Franchi. Determinação de Elementos Traço em AmostrasAmbientais por ICP OES. 2005. 90 f. Dissertação (Mestrado em Química) -Programa de Pós-Graduação em Química, Instituto de Química, UniversidadeFederal do Rio Grande do Sul, Porto Alegre, 2005.

PERIN, G.; FABRIS, R.; MANETE, S.; WAGENER, R. A.; HAMACHER, C.; SCOTTO, S. 1997. A Fiver-Year Study on the Heavy Metal Pollution of Guanabara Bay Sediments (Rio de Janeiro, Brazil) and Evaluation of the Metal Bioavailability by Means of Geochemical Speciation. Water Resources. v.31, n.12. pp. 3017-3028

PLUMMER, Charles C.; MCGEARY, David; CARLSON, Diane H. Physical geology. Wm. C. Brown, 2005, p. 580.

PROHIC, E.; JURACIC, M. Heavy metals in sediments problems concerning determination of the anthropogenic influence. Study in the Krka River Estuary, eastern 
Adriatic Coast, Yugoslavia. Environmental Geology and Water Science, v. 13, p. 145-151. 1989.

POLETO, C. 2007. Fontes potenciais e qualidade dos sedimentos fluviais em suspensão em ambiente urbano. Porto Alegre. Tese (Doutorado) Universidade Federal do Rio Grande do Sul. $137 \mathrm{f}$.

POLETO, C.; CASTILHOS, Z. C. 2008. Sedimentos e Poluição Difusa em Bacias Urbanas. In: POLETO, C. (Org.). Ambiente e Sedimentos. Porto Alegre: Associação Brasileira de Recursos Hídricos. pp. 193-227.

Poleto, C.; Gonçalves, G. R. 2006. Qualidade das Amostras e Valores de Referência. In: Poleto, C.;Merten, G. H. (Orgs.). Qualidade dos Sedimentos. Porto Alegre: ABRH, 2006. 397p.

POLETO, C.; LAURENTI, A. 2008. Sedimentos Urbanos e Corpos d'água. In: POLETO, C. (Org.). Ambiente e Sedimentos. Porto Alegre: Associação Brasileira de Recursos Hídricos. pp. 109-148.

POLETO, C.; TEIXEIRA, E. C. 2006. Processamento de Amostras e Extrações Seqüenciais. In: POLETO, C.; MERTEN, G. H. (Org.). Qualidade dos Sedimentos. Porto Alegre: ABRH - Associação Brasileira de Recursos Hídricos. pp.282-322.

POPP, J.H. Geologia geral. Rio de Janeiro: LTC. 1998.

RUBIO, B.; PYE, K.; RAE, J. E.; REY, D. 2001. Sedimentologic characteristics, heavy metal distribution and magnetic properties in subtidal sediments, Ria de Pontevedra, NW Spain. Sedimentology. v.48. pp. 1277-1296.

ROY, P.S. \& CRAWFORD, E.A. Heavy Metals in Contaminated Australian estuary Dispersion and Accumulation Trend. Estuarine Coastal And Shelf Science, v. 19, p. 341358. 1984.

SALOMONS, W.; BRILS, J. (Eds). Contaminated Sediment in European River Basins. European Sediment Research Network, SedNet. TNO Den Helder, The Netherlands, 2004. 
SANTElli, R. E., ARRUdA, M. A. Z., MECANIZAÇÃO NO PREPARO DE AMOSTRAS POR MICROONDAS: O ESTADO DA ARTE. Química Nova, v. 20, n. 6, p. $638-643,1997$.

SEZGIN, N.; OZCAN, H. K.; DEMIR, G.; NEMLIOGLU, S.; BAYAT, C. 2003. Determination of heavy metal concentrations in street dust in Istanbul E-5 highway. Environment International, v.29. pp. 979-985.

SHI, G.; CHEN, Z.; BI, C.; TENG, J.; WANG, L.; XU, S. (2010). Comprehensive assessment of toxic metals in urban and surburban street deposited sediment (SDSs) in the biggest metropolitan área of china. Evironmental Pollution 158, pp 694-703.

SiLVA. L. S.; CAMARGO, F. A. O., CERETTA, C. A. 2004. Composição da fase sólida orgânica do solo. In: MEURER, E. J. (Ed) Fundamentos de Química do Solo. Porto Alegre: Genesis. p. 73-100.

SILVA, A. M. da; SCHULZ, H. E.; CAMARGO, P. B. de. Erosão e hidrossedimentologia em bacias hidrográficas. São Carlos: Rima, 2003. 320 p.

SIMPSON, S.L.; BATLEY, G.E.; CHARITON, A.A.; STAUBER, J.L.; KING, C.K.; CHAPMAN, J.C.; HYNE, R.V.; GALE, S.A.; ROACH, A.C.; MAHER, W.A. Handbook for Sediment Quality Assessment. CSIRO, Banger, NSW, 2005. 117p.

SINGH, K. P.; MOHAN, D.; SINGH, V.K.;MAIK, S. Studies on distribution and fractionation of heavy metals in gomti river sedimentes - a tributary of the Ganges, India. Journal of Hydrology, v.312, p. 14-27, 2005.

SKJELKVÅLE B. L.; ANDERSEN, T.; FJELD E.; MANNIO, J. WILANDER, A.; JOHANSSON, K.; JENSEN, J. P.; MOISEENKO, T. 2001. Heavy Metal Surveys in Nordic Lakes: Concentrations, Geographic Patterns and Relation to Critical Limits. Ambio. V. 30, n. 1 . 
SOARES, M.C.C. et al. Análise geoquímica dos sedimentos de fundo do arroio do Salso,

Porto Alegre - RS - Brasil. Pesquisas em Geociências, Porto Alegre, v. 31, n. 1, p. 39-50. 2004.

SOLOMONS, W.; FÖRSTNER, U. Metals in the hydrocycle. Berlin: Springer, 1984. 653 p.

STRECK, E. V.; KÄMPF, N.; DALMOLIN, R. S. D.; KLANT, E.; NASCIMENTO, P. C.; SCHNEIDER, P. 2002. Solos do Rio Grande do Sul. Porto Alegre: EMATER/RS; Ed. UFRGS.

SUNDERMAN, W. F.; OSKARSSON, A. 1991. Nickel. In: MERIAN, E. (Ed.) Metals and their compounds in the environment Weinheim (Alemanha): VCH. pp. 1101-1126.

TAVARES, I. S.; PINHEIRO, R. J. B.; SOARES, J. M. D.; Notas de Aula, Mecânica dos Solos. Departamento de Transporte, Centro de Tecnologia, Universidade Federal de Santa Maria, Santa Maria, RS, Maio de 2006.

TOLEDO M.C.M., OLIVEIRA S.M.B., MELFI A. 2000. Intemperismo e formação do solo. In: TEIXEIRA W., TOLEDO M.C.M., FAIRCHILD T.R., TAIOLI F. (org.) Decifrando a Terra. Oficina de textos, São Paulo, p. 139-166

TAYLOR, K. Urban Environments. 2007. In: TAYLOR, K.; PERRY, C. Environmental Sedimentology. Manchester: Blackwell. Pp. 441.

TUCCI, C. E. M; GENZ, F. 1995. Controle do Impacto da Urbanização. In: Tucci,C.E.M.; Porto, R.L.L.; Barros, M.T. Drenagem Urbana. Porto Alegre: Ed. Universidade/UFRGS/ABRH, V.5.

UTERMANN, J.; DÜWEL, O.; NAGEL, I. (2006). Contents of trace elements and organic matter in European soils. In B. M. Gawlik \& G. Bidoglio (Eds.) Background values in European soils and sewage sludges. Results of a JRC-coordinated study on background values (Part II). European Comission DG-JRC., EUR 22265 EN. Luxembourg: Office for Official Publications of the European Communities. 
VANLOON, G. W.; DUFFY, S. J. 2005. Environmental Chemistry: A Global Perspective. New York: Oxford Press University. 2 ed. 537p.

VESTENA, L. R. Análise da relação entre a dinâmica de áreas saturadas e o transporte de sedimentos em uma bacia hidrográfica por meio de monitoramento e modelagem. 2008. 268 p. Tese (Doutorado em Engenharia Ambiental) - Universidade Federal de Santa Catarina, Florianópolis, 2008.

World Health Organization- WHO (1982) micropollutants in river sediments. World Health Organization, Copenhage.

WARD, A. D.; TRIMBLE, S. W. Environmental hydrology. $2^{\text {a }}$ ed. New York: Lewis Publishers, 1995. 475 p.

ZASOSKI, R.J.; BURAU, R.G (1988). Sorption and sorptive interactions of cadmium and zinc on hydrous manganese oxide. Soil Science Society of America Journal, v.52, p.81-87.

ZURITA, M. L. L.; TOLFO, A. M. (orgs.). 2000. A Qualidade do Ar em Porto Alegre. Porto Alegre: Secretaria Municipal de Meio Ambiente - Porto Alegre. 92p. 